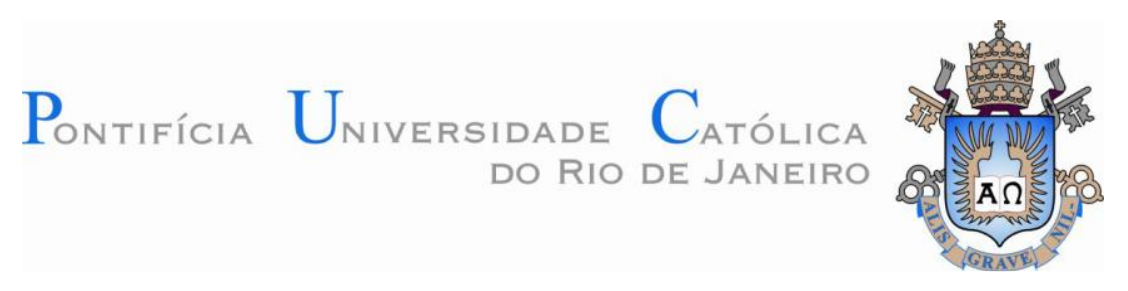

Rodrigo Sanguedo Baptista

Análise da utilização de barras de polímero reforçado com fibras de carbono para reforço de vigas de concreto

Dissertação de Mestrado

Dissertação apresentada como requisito parcial para obtenção do grau de Mestre pelo Programa de Pós-Graduação em Engenharia Civil do Departamento de Engenharia Civil e Ambiental da PUC-Rio.

Orientador: Prof. Luiz Carlos Wrobel 


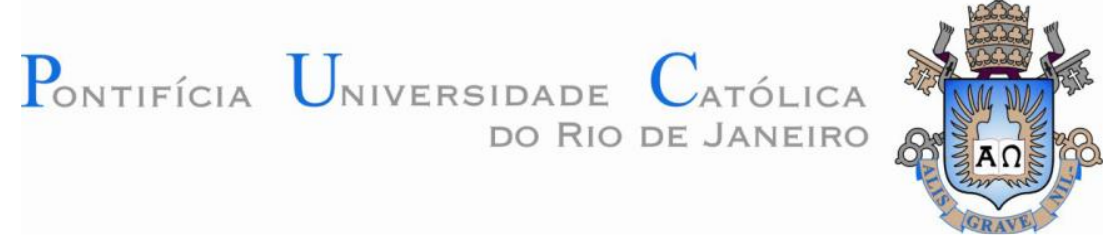

Rodrigo Sanguedo Baptista

\section{Análise da utilização de barras de polímero reforçado com fibras de carbono para reforço de vigas de concreto}

\section{Dissertação de Mestrado}

Dissertação apresentada como requisito parcial para obtenção do grau de Mestre pelo Programa de Pós-Graduação em Engenharia Civil do Departamento de Engenharia Civil e Ambiental da PUC-Rio. Aprovada pela Comissão Examinadora abaixo.

Prof. Luiz Carlos Wrobel

Orientador

Departamento de Engenharia Civil e Ambiental - PUC- Rio

Prof. Daniel Carlos Taissum Cardoso Departamento de Engenharia Civil e Ambiental - PUC- Rio

Prof. Leandro Palermo Junior

UNICAMP 
Todos os direitos reservados. É proibida a reprodução total ou parcial do trabalho sem autorização da universidade, do autor e do orientador.

\section{Rodrigo Sanguedo Baptista}

Graduou-se em Engenharia Civil pela Universidade Federal Fluminense (2017). Durante a graduação, foi monitor da disciplina de Estruturas de Concreto Armado. Ingressou na pós-graduação em agosto de 2018.

Ficha Catalográfica

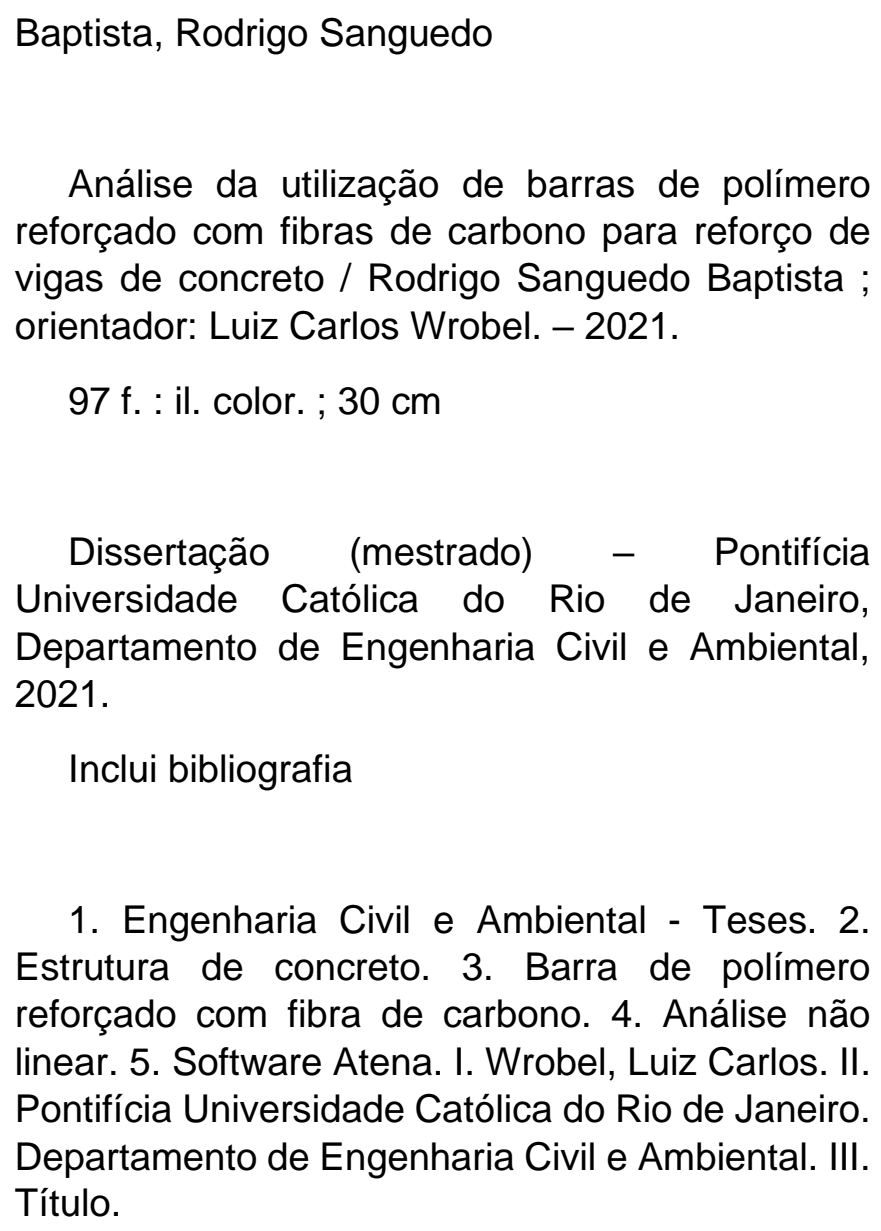

Análise da utilização de barras de polímero reforçado com fibras de carbono para reforço de vigas de concreto / Rodrigo Sanguedo Baptista ; orientador: Luiz Carlos Wrobel. - 2021.

97 f. : il. color. ; $30 \mathrm{~cm}$

Dissertação (mestrado) - Pontifícia Universidade Católica do Rio de Janeiro, Departamento de Engenharia Civil e Ambiental, 2021.

Inclui bibliografia

1. Engenharia Civil e Ambiental - Teses. 2. Estrutura de concreto. 3. Barra de polímero reforçado com fibra de carbono. 4. Análise não linear. 5. Software Atena. I. Wrobel, Luiz Carlos. II. Pontifícia Universidade Católica do Rio de Janeiro. Departamento de Engenharia Civil e Ambiental. III. Título. 


\section{Agradecimentos}

Durante o tempo em que este trabalho foi desenvolvido, entre os anos de 2020 e 2021, o mundo enfrentou e ainda enfrenta até a presente data, uma grave pandemia. Agradeço a Deus por mesmo tendo passado por diversos momentos de incerteza, ter conseguido concluir essa dissertação.

Agradeço ao meu orientador, Luiz Carlos Wrobel, por todo acompanhamento, revisões do meu trabalho e deixo registrada minha admiração por esse grande professor com quem tive a honra de desenvolver minha dissertação.

Agradeço imensamente à minha mãe, Lucia, meu pai, Wladimir, minha irmã, Mariana, meu avô, Jocenir e minha avó, Dionita, por serem pessoas fundamentais em toda a minha trajetória de vida pessoal e acadêmica. Não há dúvidas de que cada uma das minhas conquistas são em grande parte devidas à essas pessoas.

Agradeço à minha namorada, Amanda, por sempre me incentivar desde o início do mestrado durante os momentos de dificuldades e por toda a paciência durante o tempo em que este trabalho foi desenvolvido.

Agradeço à minha prima e melhor amiga, Carina, por 31 anos de amizade e tantos conselhos e palavras de incentivo durante a vida e em minha trajetória acadêmica.

Agradeço aos meus amigos, Gustavo, Gabriel e Luciano, por tantos anos de amizade desde a graduação e pelos momentos de descontração nas lives durante esse tempo tão complicado de isolamento que a humanidade enfrenta.

Agradeço ao meu amigo Felipe, por todos os anos de amizade e por toda a ajuda na minha carreira acadêmica e profissional. Aos aos meus amigos Luiz, Eduardo, Rogério, Pedro, Suelen, Ana, Hugo e Nathur, pela amizade de vários anos e pelos bons momentos durante a graduação.

Agradeço ao meu antigo professor e amigo Marcio Cataldi, pela amizade, pelos conselhos acadêmicos e tantos trabalhos que desempenhamos juntos e que contribuíram para que fosse possível meu ingresso no mestrado.

Agradeço aos professores do mestrado, por trabalharem sempre para manter a excelência do curso. Ao CNPq e à PUC-Rio, pelos auxílios concedidos, sem os quais este trabalho não poderia ter sido realizado. 
O presente trabalho foi realizado com apoio da Coordenação de Aperfeiçoamento de Pessoal de Nível Superior - Brasil (CAPES) - Código de Financiamento 001. 


\section{Resumo}

Baptista, Rodrigo Sanguedo; Wrobel, Luiz Carlos (Orientador); Análise da utilização de barras de polímero reforçado com fibras de carbono para reforço de vigas de concreto. Rio de Janeiro, 2021. 97p. Dissertação de Mestrado - Departamento de Engenharia Civil e Ambiental, Pontifícia Universidade Católica do Rio de Janeiro.

O presente trabalho tem como objetivo analisar a utilização de barras constituídas por material compósito para atuarem como reforço de vigas de concreto submetidas à flexão. As barras analisadas são constituídas por polímero reforçado com fibras de carbono (PRFC), material este que apresenta comportamento linear elástico até a ruptura. Este material possui algumas vantagens em relação ao aço, como por exemplo, resistência à tração consideravelmente superior além de não ser suscetível ao fenômeno da corrosão ocasionada por intempéries ambientais. Durante o desenvolvimento do trabalho foi obtido um artigo o qual demonstra resultados de ensaios de laboratório nos quais os autores utilizaram vigas de concreto submetidas a ensaio de flexão por quatro pontos e reforçadas com barras de PRFC. Neste trabalho, o mesmo ensaio foi simulado no software Atena, programa este que realiza análise não linear para estruturas de concreto, considerando a fissuração deste material. Os resultados obtidos pelo software apresentaram consistência com os resultados registrados em laboratório pelos autores. Foi ainda analisada uma viga contínua de concreto submetida a um carregamento uniformemente distribuído. Essa viga foi reforçada com barras de mesmo diâmetro alterando-se apenas o material dessas barras (aço e PRFC). Dessa maneira, foi analisado o valor de carregamento que ocasiona a ruptura da viga. Foram constatadas duas importantes desvantagens das barras de PRFC em relação ao aço. A primeira desvantagem está no custo superior ao aço e por apresentar comportamento elástico até o rompimento, o PRFC não confere à estrutura de concreto uma ruptura dúctil. Os objetivos deste trabalho foram cumpridos e ao final são propostos novos estudos a serem realizados sobre o tema.

\section{Palavras-chave}

Estrutura de Concreto; Barra de polímero reforçado com fibra de carbono; Análise não linear; software Atena. 


\section{Abstract}

Baptista, Rodrigo Sanguedo; Wrobel, Luiz Carlos (Advisor). Analysis of the use of carbon fiber reinforced polymer bars to reinforce concrete beams. Rio de Janeiro, 2021. 97p. Dissertação de Mestrado - Departamento de Engenharia Civil e Ambiental, Pontifícia Universidade Católica do Rio de Janeiro.

The aim of the present work is to analyze the use of bars made of composite material to act as reinforcement for concrete beams subjected to bending. The analyzed bars are constituted by polymer reinforced with carbon fibers (PRFC), a material that presents linear elastic behavior until rupture. This material has some advantages in relation to steel, such as considerably higher tensile strength in addition to not being susceptible to the phenomenon of corrosion caused by environmental conditions. During the development of the work, an article was obtained which demonstrates results of laboratory tests in which the authors used concrete beams subjected to flexion testing by four points and reinforced with PRFC bars. In this work, the same test was simulated in the Atena software, a program that performs non-linear analysis for concrete structures, considering the cracking of this material. The results obtained by the software were consistent with the results recorded in the laboratory by the authors. It was also analyzed a continuous concrete beam subjected to a uniformly distributed load. This beam was reinforced with bars of the same diameter, changing only the material of these bars (steel and PRFC. In this way, the loading value that causes the beam to break when it is reinforced with steel bars and when it is reinforced with PRFC bars of the same diameter was analyzed. Two important disadvantages of PRFC bars in relation to steel have been noted. Due to its elastic behavior until breaking, this composite material does not give the concrete structure a ductile rupture. In addition, its cost is considerably higher than steel bars, since no suppliers of this type of reinforcement have been identified in Brazil, thus increasing the cost to purchase this product. The objectives of this work were accomplished and, in the end, new studies are proposed to be carried out on the theme.

\section{Keywords}

Reinforced Concrete Structure; Carbon fiber reinforced polymer bar; Nonlinear analysis; Atena software. 


\section{Sumário}

1._Introdução 13

2._Barras poliméricas reforçadas com fibras de carbono 16

3._Análise não linear 25

3.1. Modelagem da viga BRC1 34

3.2. Modelagem da viga BRC2 36

3.3._Modelagem da viga BRS1 39

3.4._Modelagem da viga BRS2 $\quad 41$

3.5._Comparação dos resultados 43

4._Validação das simulações realizadas no Atena 47

5. Dimensionamento à flexão 53

5.1._Viga reforçada com barras de aço 53

5.2._Viga reforçada com barras de PRFC 54

5.2.1._Ruptura governada pela compressão do concreto 59

5.2.2._Ruptura governada pelo rompimento do reforço 62

5.3._Carregamento último para a viga reforçada com barras de aço 63

5.4._Carregamento último para a viga reforçada com barras de PRFC 84

5.5._Análise dos resultados 86

6. Análise de custos 88

7._Conclusões e sugestões para estudos futuros 92

8._Referências bibliográficas 95 


\section{Lista de Figuras}

Figura 1 - Vigas de concreto reforçada com barras de PRFC ou aço submetidas ao ensaio de flexão por quatro pontos (cotas na viga em

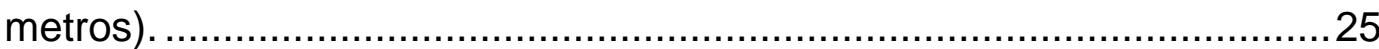

Figura 2 - Lei uniaxial de tensão-deformação para o concreto e lei biaxial de falha para esse mesmo material. 29

Figura 3 - Diagrama de tensão-deformação para as barras de PRFC. ...30 Figura 4 - Diagrama de tensão-deformação paras as barras de aço com diâmetro de $10 \mathrm{~mm}$.

Figura 5 - Diagrama de tensão-deformação paras as barras de aço com diâmetro de $8 \mathrm{~mm}$.

Figura 6 - Diagrama de tensão-deformação paras as barras de aço com diâmetro de $6 \mathrm{~mm}$. 32

Figura 7 - Incrementos de carga aplicados nas vigas BRC1 e BRC2. .....33

Figura 8 - Incrementos de carga aplicados nas vigas BRS1 e BRS2.......33 Figura 9 - Configuração das armaduras utilizadas nas vigas, apoios e pontos de monitoramento. 33

Figura 10 - Parâmetros de cálculo para a viga BRC1. 34

Figura 11 - Resultados referentes à abertura de fissura, tensão principal mínima no concreto, tensão principal máxima nas armaduras e reações verticais de apoio para o incremento de carga de $90 \mathrm{kN}$ obtidos na simulação da viga BRC1. 35

Figura 12 - Fissuras iniciais decorrente do segundo incremento de carga e respectivas reações verticais de apoio na unidade de MN. .35

Figura 13 - Diagrama de força aplicada-deslocamento vertical para a viga BRC1 36

Figura 14 - Parâmetros de cálculo para a viga BRC2. 37

Figura 15 - Resultados referentes à abertura de fissura, tensão principal mínima no concreto, tensão principal máxima nas armaduras e reações verticais de apoio para o incremento de carga de $85 \mathrm{kN}$ obtidos na simulação da viga BRC2.

Figura 16- Diagrama de força aplicada-deslocamento vertical para a viga BRC2. 
Figura 17 - Resultados referentes à abertura de fissura, tensão principal mínima no concreto, tensão principal máxima nas armaduras e reações verticais de apoio para o incremento de carga de $42,5 \mathrm{kN}$ obtidos na simulação da viga BRS1.

Figura 18 - Fissuras iniciais decorrente do quinto incremento de carga e respectivas reações verticais de apoio na unidade de MN.

Figura 19 - Diagrama de força aplicada-deslocamento vertical para a viga BRS1 41

Figura 20 - Resultados referentes à abertura de fissura, tensão principal mínima no concreto, tensão principal máxima nas armaduras e reações verticais de apoio para o incremento de carga de $40 \mathrm{kN}$ obtidos na simulação da viga BRS2.

Figura 21 - Diagrama de força aplicada-deslocamento vertical para a viga BRS2

Figura 22 - Curva de carga-deflexão no meio do vão obtida paras as vigas em questão durante os experimentos realizados por RAFI et al (2007)...44 Figura 23 - Diagrama de momento fletor que atua na viga analisada. ....48 Figura 24 - Viga BRS2 e incremento de carga utilizado para a comparação com os resultados da solução analítica 50

Figura 25 - Carga de fissuração, reações verticais de apoio correspondentes e fissuras para o carregamento em questão. 50 Figura 26 - Deflexão máxima na viga para o carregamento de 9,0 kN...51 Figura 27 - Diagrama simplificado de momento-curvatura utilizado para estimar a capacidade de rotação plástica da seção transversal analisada.

Figura 28 - Viga contínua e armadura previamente estabelecida. 65 Figura 29 - Diagrama de momentos fletores com o momento resistente de dimensionamento atuando na seção do apoio central.

Figura 30 - Diagrama de momentos fletores (kN.m) para o carregamento de $12,35 \mathrm{kN} / \mathrm{m}$ aplicado na viga.

Figura 31 - Seção transversal do apoio central da viga atuando no Estádio I.

Figura 32 - Seção transversal do apoio central da viga atuando no Estádio II. 
Figura 33 - Diagrama de momento-curvatura simplificado para a seção transversal analisada.

Figura 34 - Sistema estático equivalente para o primeiro tramo da viga analisada.

Figura 35 - Resultados de momentos fletores ao longo do sistema equivalente para o primeiro tramo da viga analisada. 78

Figura 36 - Diagrama de momento-curvatura desconsiderando o Domínio I. 79

Figura 37 - Reações de apoio e momento fletor dados por um carregamento uniformemente distribuído aplicado na viga que representa o sistema estático equivalente 80

Figura 38 - Momentos fletores para a viga submetida ao carregamento uniformemente distribuído de $18,35 \mathrm{kN} / \mathrm{m}$ 86 Figura 39 - Preço por metro da barra de polímero reforçado com fibra de carbono. Fonte: https://detail.en.china.cn/provide/p140676866.html. 88 Figura 40 - Especificações da barra de polímero reforçado com fibras de carbono apresentada na Figura $39 . \quad$ Fonte: https://detail.en.china.cn/provide/p140676866.html. .............................89 Figura 41 - Exemplo de barra de polímero reforçado com fibras de carbono. Fonte: https://www.kimia.it/sites/default/files/docs/st/en-kimitech-tondocb.pdf. 89 Figura 42 - Exemplo de barra de aço para reforço de estruturas de concreto. Fonte: https://loja.arcelormittal.com.br/vergalhao-ca50-10-00mmreto-12-metros/p. 


\section{Lista de Tabelas}

Tabela 1 - Característica do concreto no $28^{\circ}$ dia para cada uma das vigas

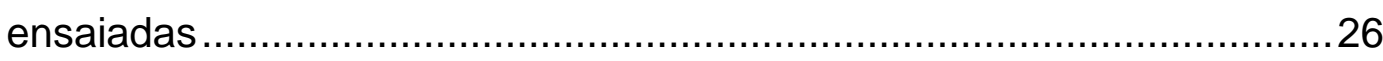

Tabela 2 - Características mecânicas das barras utilizadas para reforço das vigas 26

Tabela 3 - Parâmetros resultantes dos ensaios de flexão por quatro pontos.

Tabela 4 - Resultados obtidos pelas análises das vigas realizadas no Atena.

Tabela 5 - Resultados da carga de fissuração e deflexão máxima na viga.

Tabela 6 - Fatores de redução para as diferentes fibras de acordo com a exposição ambiental (ACl 440-2015).

Tabela 7 - Valores típicos para a taxa balanceada de reforço para uma seção retangular de concreto com $f c^{\prime}=34,5 \mathrm{MPa}(\mathrm{ACl}$ 440-2015). 56 Tabela 8 - Parâmetros utilizados no cálculo dos momentos fletores e curvaturas da seção transversal em cada um dos trechos do diagrama de momento-curvatura. 


\section{1.}

\section{Introdução}

Nas construções da antiguidade, os materiais estruturais mais empregados foram inicialmente a pedra e a madeira e posteriormente as ligas metálicas. Um importante avanço ocorreu com o desenvolvimento dos chamados materiais aglomerantes, os quais endurecem em contato com a água e tornaram possível a fabricação do concreto, material este que apresenta boa resistência à compressão, mas baixa resistência à tração. Desde o surgimento do concreto, foi sendo ampliada a utilização deste material nas construções, entretanto, era necessário encontrar uma solução para a sua resistência limitada à tração. Dessa busca surgiu o concreto armado, material estrutural que associa ao concreto um componente com resistência satisfatória à tração, denominado armadura (CLíMACO, 2016).

O concreto armado é um material formado pela junção de barras de aço que são inseridas na massa de concreto criando aderência durante o processo do seu endurecimento. A aderência entre as barras de aço e o concreto permite que esses dois elementos trabalhem em conjunto e formem como resultado o concreto armado, possibilitando a existência de um material no qual os esforços de tração são suportados pelo aço e os esforços de compressão resistidos pelo concreto. A baixa resistência do concreto à tração faz com que esse material trabalhe fissurado nas regiões em que o elemento estrutural está tracionado e essas fissuras permitem que intempéries ambientais possam incidir sobre as barras de aço que compõem o reforço.

A atuação do meio ambiente sobre essas barras de aço pode dar início ao processo de corrosão da armadura, reduzindo assim a sua resistência à tração. Visando evitar esse processo, é possível adotar algumas medidas preventivas, como estabelecer cobrimentos nas peças de concreto armado e limitar a abertura das fissuras nesses elementos. Segundo RAFI et al. (2007), a utilização do aço para reforço de estruturas de concreto é tradicional na indústria da construção, entretanto, novos materiais não metálicos, vêm sendo introduzidos como reforço de estruturas de concreto visando evitar o problema da corrosão que pode ocorrer nas barras de aço. Esses novos materiais não metálicos são barras de polímeros reforçados com fibras (PRF), como por exemplo, fibras de aramida, vidro e carbono.

A norma brasileira que estabelece as diretrizes para o projeto de estruturas de concreto é a NBR 6118:2014. Essa norma trata do dimensionamento de estruturas de 
concreto armado através do método dos Estados Limites, o qual se dá de maneira a majorar as solicitações que atuam nas estruturas e minorar as resistências dos materiais. O único material tratado na NBR 6118:2014 para compor as armaduras é o aço, não existindo no Brasil uma norma que estabeleça critérios de dimensionamento de estruturas de concreto reforçadas com barras de polímero reforçado com fibras, apesar de estar sendo desenvolvido no presente momento por um grupo de trabalho da ABECE/IBRACON um documento com recomendações para o projeto desse tipo de estrutura.

Este trabalho tem o objetivo de apresentar a utilização de barras de polímero reforçado com fibras de carbono (PRFC) como reforço em elementos de concreto ao invés das convencionais barras de aço. Além disso foi realizada a análise de modelos que representem esses elementos para a comparação dos resultados com aqueles obtidos experimentalmente e apresentados em artigos da literatura sobre o assunto. Pretendese também neste trabalho, apresentar um dimensionamento de armadura de flexão para uma seção de viga submetida a um momento fletor utilizando como reforço barras de aço de acordo com a NBR 6118:2014 e barras de PRFC de acordo com a norma norteamericana $\mathrm{ACl}$ 440:2015. Para a realização dos modelos, foi utilizado o software Atena (Advanced Tool for Engineering Nonlinear Analysis), da empresa Cervenka Consulting, o qual realiza a análise não linear de estruturas de concreto baseando-se no método de elementos finitos.

A justificativa para o tema do presente trabalho é contribuir com o estudo da utilização de barras poliméricas reforçadas com fibras de carbono para reforço de estruturas de concreto e dessa maneira, fornecer subsídio para a elaboração no Brasil de uma norma regulamentadora que estabeleça as diretrizes para a utilização deste tipo de reforço no projeto de estruturas de concreto. Segundo SHAMASS e CASHELL (2020), existem algumas normas internacionais para o projeto de estruturas de concreto reforçadas com FRP, como por exemplo, a americana ACl 440.1 R-06, a canadense CSA S806-02 e a russa SP295. Essas normas aplicam-se ao projeto de estruturas de concreto reforçadas com barras de polímero reforçado com fibras de carbono, vidro e aramida. Os autores ainda indicam que não há normas britânicas ou europeias para o projeto de estruturas de concreto reforçadas com barras de PRF.

Como é possível verificar, alguns países como Estados Unidos, Canadá e Rússia já possuem atualmente normas para o projeto de estruturas de concreto que utilizam como reforço as barras poliméricas reforçadas com fibras. Tendo em vista as vantagens desse tipo de reforço em relação à utilização das barras de aço convencionais no que diz respeito 
à corrosão, o presente trabalho pretende contribuir com um estudo relevante que possa ser utilizado para auxiliar na elaboração futura de uma norma brasileira de projeto de estruturas de concreto reforçadas com barras de polímero reforçado com fibras.

No presente capítulo realizou-se uma introdução sobre o tema abordado neste trabalho. No capítulo 2 é realizada uma revisão de trabalhos científicos publicados na literatura sobre as características observadas em estruturas de concreto reforçadas com barras de polímero reforçado com fibras de carbono que foram submetidas a diversos tipos de experimentos em laboratório. No capítulo 3 foi realizada uma comparação entre os resultados obtidos em um ensaio de flexão por quatro pontos para vigas de concreto reforçado com barras de polímero reforçado com fibras de carbono e os resultados obtidos através de simulações realizadas no software Atena. No capítulo 4 foi realizada uma validação do software Atena para o uso desse programa no presente trabalho. Foram comparados resultados gerados nas simulações de vigas de concreto armado com os resultados provenientes de soluções analíticas para um problema simples. No capítulo 5 é realizado um exemplo comparativo entre o dimensionamento de vigas de concreto submetidas à flexão utilizando barras de polímero reforçado com fibras de carbono e vigas de concreto utilizando barras de aço. No $6^{\circ}$ capítulo é realizada uma análise simplificada dos custos para se utilizar barras de aço e barras de polímero reforçado com fibras de carbono como reforço de estruturas de concreto. O capítulo 7 reúne as conclusões observadas durante a realização do presente trabalho e o capítulo 8 apresenta as referências bibliográficas utilizadas como base científica para o desenvolvimento deste texto. 


\section{2.}

\section{Barras poliméricas reforçadas com fibras de carbono}

Para utilizar um determinado tipo de reforço nas estruturas de concreto é necessário estudar o funcionamento mecânico do material que constitui o reforço e a aderência entre este e o concreto. Isso é fundamental para iniciar o desenvolvimento de um processo de cálculo que permita dimensionar estruturas de concreto reforçadas com o material em questão. Neste capítulo é apresentado um conjunto de trabalhos científicos no tema da utilização de barras poliméricas reforçadas com fibras de carbono para serem utilizadas como reforço de estruturas de concreto em detrimento das barras de aço convencionais. Isso é importante para que se compreenda as características deste reforço e a maneira com que se desenvolve sua ação conjunta com o concreto.

NANNI et al. (2014) publicaram o livro "Reinforced Concrete with FRP Bars: Mechanics and Design" no qual os autores apresentaram as características gerais das barras de polímero reforçado com fibras. O comportamento à tração é caracterizado pela relação de tensão-deformação linear elástica até o momento em que atinge a ruptura. Quando comparadas com as barras de aço, as barras de polímero reforçado com fibras apresentam maior resistência à tração, porém deformação máxima e módulo de elasticidade inferiores. As estruturas de concreto reforçadas com barras de aço apresentam a possibilidade de redistribuição de momentos fletores devido a este material apresentar um patamar de deformações plásticas após atingir sua tensão de escoamento. Isso significa que o aço não rompe no momento em que sua resistência ao escoamento é alcançada. Quando essa tensão é atingida, esse material adquire ainda uma certa resistência e passa a deformar-se em regime plástico até igualar sua deformação última. O fato de as barras de polímero reforçado com fibras apresentarem relação de tensãodeformação linear elástica até a ruptura não permite, portanto, a possibilidade de redistribuição de momentos fletores em elementos de concreto reforçados com esse tipo de barras.

BENMOKRANE et al (2002) desenvolveram um trabalho em que foram realizados testes experimentais de tração para dois tipos de barras poliméricas reforçadas com fibras de carbono (PRFC), sendo o primeiro constituído por barras com revestimento de areia (9,5 mm de diâmetro) e o segundo por barras com nervuras ( $9,0 \mathrm{~mm}$ de diâmetro). Foram realizados 20 ensaios para cada um dos dois tipos de barras. Tanto o revestimento de areia quanto as nervuras foram inseridos nas barras para garantir maior qualidade na 
aderência entre o reforço e o concreto, pois essa é uma condição importante para as propriedades mecânicas do elemento estrutural. As barras revestidas com areia atingiram resistência à tração de $1536 \pm 61 \mathrm{MPa}$ (aproximadamente três vezes superior à resistência do aço (A-50) e aquelas com nervuras apresentaram resistência de $2138 \pm 96$ $\mathrm{MPa}$ (aproximadamente quatro vezes superior à resistência do aço CA-50). Os dois tipos de barras apresentaram módulo de elasticidade entre 128 GPa e 145 GPa, ou seja, de 64\% a $72 \%$ do módulo de elasticidade de 200 GPa comumente considerado para o aço. A curva de tensão-deformação das barras de polímero reforçado com fibras de carbono apresentou-se de maneira praticamente linear elástica até a ruptura. Foram ainda realizados testes de arrancamento para estudar a aderência entre cinco comprimentos diferentes das barras embutidas no concreto. O comprimento embutido considerado ótimo foi aquele a partir do qual é possível mobilizar por completo a tensão resistente de tração da barra antes de seu rompimento. O valor do comprimento ótimo obtido para os dois tipos de barras foi de $215 \mathrm{~mm}$ para as barras revestidas com areia e $290 \mathrm{~mm}$ para as barras nervuradas.

RAFI. et al. (2007) estudaram o comportamento à flexão de duas vigas de concreto reforçadas com barras poliméricas contendo fibras de carbono (PRFC). Cada viga apresentou seção retangular de $12 \mathrm{~cm} \times 20 \mathrm{~cm}$, comprimento de $2 \mathrm{~m}$ e foi reforçada com duas barras longitudinais de PRFC com 9,5 mm de diâmetro em sua face inferior, duas barras longitudinais de aço com $8 \mathrm{~mm}$ de diâmetro em sua face superior e estribos de aço com diâmetro de $6 \mathrm{~mm}$ distribuídos a cada $10 \mathrm{~cm}$. Para meio de comparação com o reforço convencional, foram também construídas duas vigas com mesma armadura longitudinal superior e estribos, mas alterando-se as barras da face inferior para duas barras de aço com diâmetro de $10 \mathrm{~mm}$. As barras PRFC foram constituídas pela fração de $60 \%$ do volume formado por fibras contínuas de carbono e resina bisphenol epoxy vinyl ester, apresentando resistência à tração de $1676 \mathrm{MPa}$ e módulo de elasticidade de 135,9 GPa. Foi acrescentada uma textura na superfície das barras através do tratamento dessas superfícies a fim de melhorar a aderência entre o reforço e o concreto. As vigas foram submetidas a ensaios de flexão por quatro pontos e tanto aquelas reforçadas com barras PRFC quanto aquelas reforçadas com barras de aço apresentaram padrão similar de fissuras. As barras de PRFC apresentaram boa aderência com o concreto, não tendo sido registrado nenhum sinal de falha por aderência e nenhum deslizamento durante os testes. As vigas reforçadas com barras de PRFC romperam por esmagamento do concreto, enquanto as vigas reforçadas com barras de aço atingiram o rompimento após o reforço tracionado atingir sua resistência à tração. As tensões de tração máximas nas barras de 
PRFC foram de $80 \%$ a $90 \%$ da sua tensão de ruptura e desenvolveram uma tensão aderente superior a $85 \%$ daquela proveniente das barras de aço. Após a fissuração, as vigas reforçadas com barras de PRFC apresentaram deflexão superior às vigas reforçadas com barras de aço, entretanto, após o aço atingir o escoamento, a taxa de deflexão das vigas reforçadas com este material foi superior a aquelas reforçadas com barras de PRFC. Um trabalho desenvolvido por Wang et al (2021), com o título Short-Term Flexural Stiffness Prediction of CFRP Bars Reinforced Coral Concrete Beams, tratou de estudar a rigidez à flexão de vigas de concreto em que o agregado grosso utilizado na sua composição é composto por resíduos de corais do mar do sul da China enquanto o agregado fino é composto por areia de rio. O concreto produzido dessa maneira vem sendo gradualmente utilizado na área costeira e nas ilhas para construção civil devido às suas características favoráveis ao meio ambiente, pois o uso desse tipo de agregado e até mesmo da água marinha são fatores que reduzem significativamente os custos de produção e transporte do concreto. No entanto, a salinidade presente nas áreas costeiras, nesses agregados e na água do mar, gera o problema de corrosão nas barras de aço comuns utilizadas para reforçar as estruturas de concreto. Tendo em vista esse problema, as barras de polímero reforçado com fibra têm sido amplamente utilizadas devido às suas boas propriedades mecânicas e excelente resistência à corrosão, o que fornece uma nova solução para a durabilidade de estruturas de concreto produzidas dessa maneira. Foram submetidas vigas de concreto reforçadas com barras de polímero reforçado com fibras de carbono e vigas de concreto reforçadas com barras de aço a ensaios de flexão por quatro pontos. Foram utilizadas barras de PRFC com diâmetros de $8 \mathrm{~mm}, 10 \mathrm{~mm}$ e $12 \mathrm{~mm}$, sendo as resistências à tração dessas barras em torno de 1628,3 MPa, 1515,9 MPa e 1910,8 MPa respectivamente e módulos de elasticidade em torno de 106,4 GPa, 108,6 GPa e 111 GPa respectivamente. Em relação à curva de carga-deflexão no meio do vão, os resultados apontaram que após ocorrer a fissuração do concreto, a rigidez das vigas reforçadas com barras de PRFC sofre importante redução, acelerando a taxa de deflexão. $\mathrm{O}$ aumento da taxa de reforço das vigas com barras de PRFC gera uma elevação da rigidez à flexão dessas vigas, reduzindo a deflexão no meio do vão. A máxima deflexão permitida analisada pelos autores se deu como sendo o comprimento do vão dividido por 200. Para essa deflexão, conforme ocorre o aumento da taxa de reforço, as tensões registradas nas barras passam a ser cada vez menores em relação à tensão resistente última dessas barras. Em relação às fissuras, os autores observaram que sob o mesmo carregamento, a largura das fissuras nas vigas reforçadas com barras de PRFC apresentaram-se superiores à aquelas registradas nas vigas reforçadas com barras de aço. Foi notado pelos autores que em 
quase todas as vigas de concreto produzidas com resíduos de corais, areia e água do mar reforçadas com barras de PRFC ocorreu deslizamento entre as barras do reforço e o concreto. Eles observaram que quanto menor o diâmetro das barras, maior é esse deslizamento entre o reforço e o concreto. Para as vigas reforçadas com barras de aço não foram registrados deslizamentos entre as barras e o concreto.

Um estudo realizado por KRASNIQI et al (2020) com o título Flexural cracks in fibre-reinforced concrete beams with fibre-reinforced polymer reinforcing bars, analisou a utilização de fibras na massa de concreto para verificar a abertura de fissuras em vigas de concreto submetidas à flexão reforçadas com barras de PRF. Segundo os autores, as barras de PRF apresentam geralmente menor módulo de elasticidade e menor aderência entre sua superfície e o concreto quando comparadas com as barras de aço. Isso faz com que as vigas de concreto reforçadas com barras de PRF apresentem fissuras com aberturas maiores e deflexões superiores do que aquelas encontradas nas vigas reforçadas com barras de aço. Além disso, outra desvantagem da utilização de barras de PRF para reforço de vigas de concreto é o comportamento linear elástico até a ruptura que esse tipo de reforço apresenta, não possuindo, portanto, deformações em regime plástico. A utilização de fibras curtas, uniformemente distribuídas com orientação aleatória na massa do concreto faz com que essas fibras conectem duas faces de uma mesma fissura e dessa maneira, haja o controle do desenvolvimento das fissuras e redução de suas aberturas. Foram construídas três vigas de concreto sem fibras reforçadas com duas barras de polímero reforçado com fibras de vidro (PRFV) com $6 \mathrm{~mm}$ de diâmetro e outras três vigas semelhantes, porém reforçadas com duas barras de PRFV com $8 \mathrm{~mm}$ de diâmetro. Além dessas, foram produzidas três vigas de concreto contendo fibras e reforçadas com duas barras de PRFV com $6 \mathrm{~mm}$ de diâmetro e outras três com duas barras de PRFV com $8 \mathrm{~mm}$ de diâmetro. Duas vigas de concreto sem fibras e reforçadas com duas barras de aço com $8 \mathrm{~mm}$ de diâmetro foram construídas para comparação dos resultados. Para a produção do concreto com fibras foram utilizadas fibras de polipropileno em um volume de 0,063\%, resistência à tração de $650 \mathrm{MPa}$, módulo de elasticidade de 3,5 GPa e $12 \mathrm{~mm}$ de comprimento. As barras de PRFV com 6 $\mathrm{mm}$ de diâmetro apresentaram resistência à tração de $1022 \mathrm{MPa}$ e módulo de elasticidade de 50,59 GPa, enquanto as barras de PRFV com $8 \mathrm{~mm}$ de diâmetro apresentaram 1108,2 MPa para a resistência à tração e 54,3 GPa para o módulo de elasticidade. As barras de aço apresentaram $500 \mathrm{MPa}$ de resistência à tração e $200 \mathrm{GPa}$ para o módulo de elasticidade. Cada viga possuiu seção transversal retangular de $13 \mathrm{~cm} x$ $22 \mathrm{~cm}$ e $200 \mathrm{~cm}$ de vão entre os apoios. Todas as vigas foram submetidas ao ensaio de 
flexão por quatro pontos. A partir dos experimentos os autores puderam analisar os coeficientes de aderência utilizados para o cálculo da abertura de fissuras propostos por alguns estudos, como, por exemplo, a ACl e o Eurocode 2. As vigas com taxa de armadura próximas da taxa balanceada apresentaram boa correlação com os coeficientes de aderência, enquanto as vigas com taxas de armadura mínima apresentaram características de aderência inferiores. Os autores também concluíram que para este estudo, a fração de fibras utilizadas na produção das vigas de concreto com fibras não foi suficiente para influenciar o comportamento pós fissuração do concreto.

Um trabalho desenvolvido por GODAT et al (2020) com o título Bond strength of FRP bars in recycled-aggregate concrete, realizou um estudo experimental a fim de investigar a resistência de aderência de barras de PRF inseridas em concreto produzido com agregados reciclados e comparar com a resistência de aderência dessas barras inseridas em concreto produzido com agregado comum. 0 experimento constou de 36 amostras as quais foram submetidas ao ensaio de arrancamento, tendo sido utilizadas barras de polímero reforçado com fibras de vidro (PRFV), carbono (PRFC) e basalto (PRFB) com $12 \mathrm{~mm}$ de diâmetro e comprimento ancorado na massa de concreto de 5 vezes o diâmetro da barra. Os concretos com agregados reciclados que foram utilizados para inserir as barras apresentaram resistência à compressão de $30 \mathrm{MPa}, 45 \mathrm{MPa}$ e $60 \mathrm{MPa}$. $\mathrm{O}$ concreto com agregado comum apresentou resistência à compressão de $30 \mathrm{MPa}$. $\mathrm{O}$ comportamento das barras no concreto com agregados comuns foi utilizado como parâmetro para comparar o comportamento dessas barras no concreto com agregados reciclados. Os autores concluíram durante o estudo que em geral, não há impacto negativo no comportamento de aderência das barras de PRF quando são utilizados agregados graúdos reciclados na produção do concreto. A rigidez inicial e a tensão máxima de aderência foram idênticas para o concreto com agregado reciclado e para o concreto com agregado natural. Entretanto, o deslizamento das barras em concreto com agregado reciclado após atingir a tensão máxima de aderência foi bastante diferente entre os tipos de barras. As barras de PRFB apresentaram maiores deslizamentos após atingir a tensão máxima de aderência nos concretos com agregado reciclado, já as barras de PRFC foram as que registraram menores deslizamentos após atingirem a tensão máxima de aderência. Os autores justificaram isso atrelando aos diferentes tratamentos realizados nas superfícies de cada um dos tipos de barras. Os autores verificaram ainda, que no caso do concreto com agregado reciclado, um aumento na tensão de aderência e uma mudança no modo de ruptura de arrancamento para fendilhamento do concreto podem ser obtidos aumentando a resistência desse material. 
Um estudo realizado por KHAMIES e MEDHLOM (2021), com o título Effect of impact load on the performance of concrete slabs reinforced by CFRP bars, investigou a influência da espessura da laje, do material que forma as barras de reforço, do arranjo do reforço e da queda de uma massa no comportamento dinâmico em lajes de concreto armado. Foram utilizados sete corpos de prova com dimensões de 1550 x 1550 mm com duas espessuras distintas, sendo uma de $120 \mathrm{~mm}$ e a outra de $150 \mathrm{~mm}$. Desses sete corpos de prova, um foi reforçado com barras de aço e os outros seis com barras de polímero reforçado com fibras de carbono (PRFC). Os corpos de prova foram investigados experimentalmente sob queda de peso sequencial variando de $50 \mathrm{~kg}$ a $150 \mathrm{~kg}$. O peso utilizado foi um projétil rígido de aço e a altura de queda foi de 2,5 m. Para estimar a profundidade de penetração, três fórmulas empíricas foram utilizadas. Diferentes códigos foram usados para calcular a capacidade de cisalhamento por punção e a velocidade crítica de perfuração e comparados os resultados experimentais com esses códigos. Os resultados experimentais mostraram que as propriedades de cisalhamento das lajes têm um efeito significativo no seu comportamento geral. Os autores chegaram a algumas conclusões, dentre elas, que nenhum dos corpos de prova falharam com o primeiro golpe do peso de $150 \mathrm{~kg}$, tendo sido então realizados novos golpes com esse peso até que a falha ocorresse nos corpos de prova. Conforme cresceu o número de golpes com o peso de $150 \mathrm{~kg}$, foi sendo separado o cone de punção formado como resultado de golpes anteriores do restante da laje e o comportamento da laje sob cargas de impacto passa a deixar de ser global e se transforma em local. Em relação ao deslocamento do ponto central onde a carga de impacto incide, os autores observaram que o valor do deslocamento aumenta com o aumento da massa de queda do mesmo corpo de prova. Foi observado que os picos mínimos de deslocamento dos corpos de prova com mesma espessura são semelhantes para a mesma carga de impacto, diferenciando-se ligeiramente de acordo com a taxa de distribuição do reforço. Os autores utilizaram três equações para estimar a profundidade de penetração por impacto e comparar os resultados com aqueles observados nos experimentos. Foram utilizadas as equações da U.S. Army Corps of Engineers (ACE), do National Defense Research Committee (NDRC) Modified e de Petry Modificado. Os resultados previstos pela ACE foram os que apresentaram mais proximidade a aqueles registrados nos experimentos, enquanto os resultados provenientes da NRDC acabaram gerando valores subestimados, pois o fator de forma do projétil acabou por afetar esses valores.

Um trabalho realizado pelos autores AFIFI et al (2013) com o título Strength and Axial Behavior of Circular Concrete Columns Reinforced with CFRP Bars and Spirals, 
estudou o comportamento à compressão de 11 pilares circulares de concreto reforçados com barras de polímero reforçado com fibras de carbono (PRFC) e estribos circulares em espiral também compostos por PRFC. As variáveis testadas foram o tipo de reforço (aço ou PRFC), taxa de reforço longitudinal de barras de PRFC, taxa volumétrica, tamanho e espaçamento dos estribos de PRFC em espiral. Os autores obtiveram algumas conclusões, dentre elas, que os pilares com barras de PRFC e aço comportaram-se de maneira semelhante até os picos de carga. As capacidades axiais dos pilares reforçados com barras de PRFC foram em média $5 \%$ menores do que utilizando o reforço com barras de aço. As barras de PRFC desenvolveram até $0,75 \%$ de deformação de compressão, confirmando que essas barras foram eficazes em resistir à compressão até após o esmagamento do concreto. As barras de PRFC contribuíram em média com 13\% da capacidade da coluna, aproximando-se da contribuição do aço (16\%). As observações indicaram que a falha dos pilares reforçados com barras de PRFC com grande espaçamento entre os estribos em espiral ou com pequena relação volumétrica $(0,7 \%)$ foi controlada pelo plano de cisalhamento diagonal através das barras longitudinais e espirais. Por outro lado, a falha dos pilares reforçados com barras de PRFC bem confinadas foi atribuída ao esmagamento do núcleo de concreto e ruptura das espirais de PRFC. O efeito do espaçamento da espiral de PRFC na eficiência do confinamento e na ductilidade foi bem mais pronunciado do que na capacidade de resistência. A ductilidade e a eficiência de confinamento do núcleo de concreto podem ser melhoradas usando espirais de PRFC de tamanho menor com espaçamento menor ao invés de espirais de diâmetro maior com espaçamento maior. As amostras reforçadas com barras de PRFC com espaçamento menor e diâmetros menores apresentaram comportamento dúctil no estágio pós pico de carga, fazendo com que o pilar falhasse de maneira mais gradual do que aqueles com espirais de PRFC maiores em espaçamentos maiores. Os pilares reforçados com barras de PRFC falharam de maneira frágil e explosiva quando confinados com relações volumétricas menores que 1,5\% ou com espaçamento da espiral acima de $80 \mathrm{~mm}$, mesmo em relações volumétricas maiores que $1,5 \%$.

Um estudo realizado por HADHOOD et al (2016), com o título Axial Load-Moment Interaction Diagram of Circular Concrete Columns Reinforced with CFRP Bars and Spirals: Experimental and Theoretical Investigations, abordou um programa experimental para investigar o desempenho estrutural de 10 pilares circulares de concreto reforçados com barras de polímero reforçado com fibras de carbono (PRFC) e estribos espirais. Estes pilares foram submetidos a cargas de compressão axial combinadas com momentos fletores. As variáveis analisadas nos experimentos incluíram diferentes excentricidades e 
tipos de reforço (PRFC ou aço). O reforço de PRFC possuía superfície revestida de areia para melhorar o desempenho de adesão entre as barras e o concreto. Para as barras de PRFC longitudinais foi utilizado diâmetro de 15,9 mm, enquanto que para os estribos em espiral de PRFC foi utilizado o diâmetro de $9,5 \mathrm{~mm}$. Para as barras de aço longitudinais foi utilizado o diâmetro de $16 \mathrm{~mm}$ e para os estribos em espiral de aço o diâmetro de 9,5 mm. As amostras foram reforçadas com 8 barras longitudinais (PRFC ou aço). Os autores puderam observar alguns resultados, tendo estes mostrado que os pilares reforçados com barras de PRFC e de concreto armado com aço se comportaram de forma semelhante até seus picos de carga. A ruptura dos corpos de prova sob diferentes níveis de excentricidade não foi desencadeada pelo rompimento das barras de PRFC no lado da tração, mas sim pelo esmagamento gradual do concreto, seguido do esmagamento das barras no lado da compressão. Quatro níveis diferentes de carga excêntrica foram aplicados e classificados em baixo, moderado, alto e extremo para razões de excentricidade em relação ao diâmetro do pilar $(e / d)$ 8,2\%, 16,4\%, 32,8\% e 65,6\%, respectivamente. A capacidade de carga e resistência à flexão dos pilares reforçados com barras de PRFC foram em média $4 \%$ mais baixas do que utilizando barras de aço em carregamento excêntrico baixo, moderado e alto, e foram em média $2 \%$ maiores para o carregamento excêntrico extremo. O reforço com barras de PRFC pode ser utilizado como um reforço interno em pilares com carregamento excêntrico, desde que a resistência máxima à compressão possa ser limitada a $40 \%$ da resistência à tração final do reforço. As barras de PRFC foram eficazes na resistência às tensões de compressão e tração. A deformação máxima de compressão desenvolvida nas barras foi de $0,51 \%$ quando as barras mais externas foram esmagadas, embora a deformação máxima de tração desenvolvida nas barras foi de 0,9\% (76\% da deformação de tração final) quando o teste foi interrompido. Os modos e mecanismos de falha foram afetados pelo nível de carregamento excêntrico aplicado. No entanto, a falha dos pilares com barras de PRFC não foi desencadeada pela ruptura das barras no lado da tração. Diferentes modos de falha foram observados para as diferentes resistências dos concretos. A amostra C-25 exibiu falha por compressão frágil atribuída ao esmagamento do concreto, esmagamento de quatro barras de compressão (no lado da compressão) e ruptura das espirais no lado da compressão. A amostra C-50 exibiu falha por compressão atribuída ao esmagamento do concreto e esmagamento das barras de compressão mais externas. As amostras com C-100 e C-200 exibiram falha por flexo-compressão atribuída à propagação de fissuras profundas e largas no lado da tração com uma largura média de $1 \mathrm{~mm}$, acompanhada pela degradação do concreto e esmagamento devido às limitações de deformação e, por último, esmagamento das barras de compressão mais externas. 
Um estudo desenvolvido por FILHO e REAL (2018), com o título Estudo comparativo entre vigas de concreto armadas com barras de aço e com barras de PRF, realizou um estudo comparativo do dimensionamento de vigas biapoiadas de concreto armado reforçadas com barras de aço e com os três tipos de polímero reforçado com fibras (PRF), sendo estas fibras de aramida, carbono e vidro. Para as vigas reforçadas com barras de aço o dimensionamento se deu de acordo com as recomendações da NBR 6118:2014, enquanto que para as vigas reforçadas com barras de PRF esse dimensionamento foi baseado no que é indicado pela norma norte-americana $\mathrm{ACl}$ 440:2015. Foram analisadas 40 vigas biapoiadas, com vãos variando de 0,5 m em 0,5 m iniciando em 2,5 m e finalizando em 7,0 m. Para cada material de reforço (PRFA, PRFV, PRFC e aço) foram consideradas 10 vigas com seção transversal retangular com base de $25 \mathrm{~cm}$ e altura variando de acordo com o comprimento do vão, sendo 1/8 desse comprimento. Todas as vigas foram submetidas a um carregamento uniformemente distribuído de $15 \mathrm{kN} / \mathrm{m}$ para cargas permanentes e $20 \mathrm{kN} / \mathrm{m}$ para as cargas acidentais. As propriedades mecânicas das barras foram adaptadas da ACl 440:2015 e o concreto utilizado foi o C-25. Os autores concluíram que a área da armadura de aço pode ser superior ou inferior às armaduras de PRF a depender do tipo de fibra utilizada. As vigas reforçadas com barras de PRFV apresentaram as maiores áreas de armadura dentre as vigas analisadas para todos os vãos, as vigas de PRFA apresentaram valores de armaduras próximos das áreas de armadura de aço para todos os vãos e as vigas reforçadas com barras de PRFC apresentaram áreas de armadura inferiores às armaduras de aço também para todos os vãos. Em relação às flechas das vigas, verificou-se valores maiores de flechas para as vigas reforçadas com barras de PRF e segundo os autores, isso se dá devido a menor rigidez causada pelo baixo módulo de elasticidade do material em relação ao aço. Em uma escala decrescente dos valores de flecha, em primeiro lugar encontram-se as vigas reforçadas com barras de PRFC com os maiores valores de flecha, seguidas das vigas reforçadas com barras de PRFA, PRFV e aço, a qual apresentou os menores valores de deflexão. 


\section{3.}

\section{Análise não linear}

Foram realizadas através do software Atena, da empresa Cervenka Consulting (CERVENKA et al, 2018), as modelagens das quatro vigas submetidas ao ensaio de flexão por quatro pontos apresentado no trabalho de RAFI et al (2007) descrito no capítulo 2 do presente texto. $O$ software em questão realiza simulações não lineares, considerando a fissuração em elementos de concreto por meio do método dos elementos finitos. Das quatro vigas analisadas, as vigas BRC1 e BRC2 possuem barras de polímero reforçado com fibras de carbono para seu reforço à tração, enquanto as vigas BRS1 e BRS2 possuem barras de aço para esse reforço. A geometria das vigas e suas armaduras de reforço estão apresentadas na Figura 1.

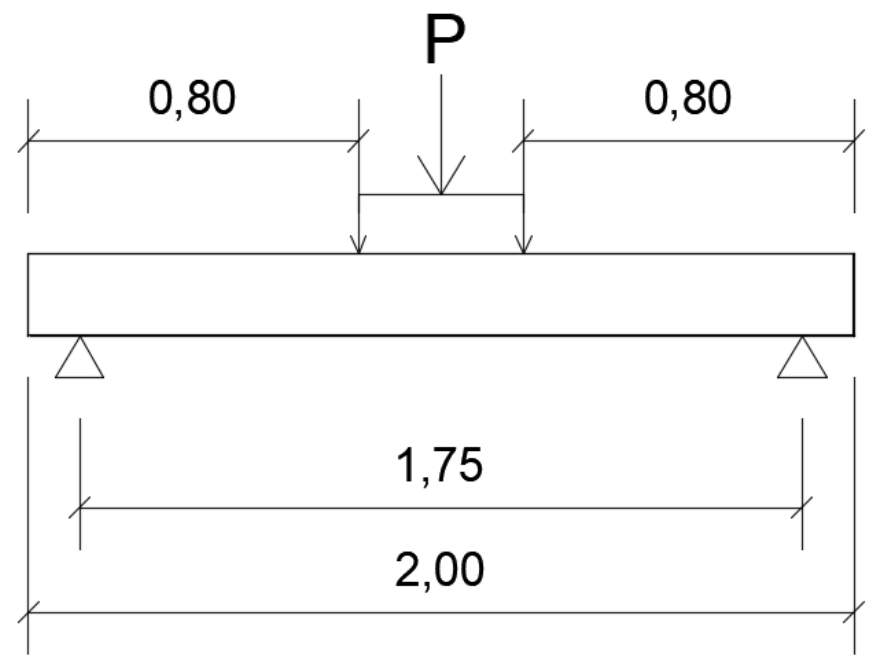

Figura 1 - Vigas de concreto reforçada com barras de PRFC ou aço submetidas ao ensaio de flexão por quatro pontos (cotas na viga em metros).

As características do concreto no $28^{\circ}$ dia para cada uma das quatro vigas ensaiadas podem ser observadas na Tabela 1, enquanto as características das barras utilizadas para reforçar as vigas durante os experimentos no laboratório são demonstradas na Tabela 2. Na Tabela 3 estão apresentados os resultados dos ensaios. 
Tabela 1 - Característica do concreto no $28^{\circ}$ dia para cada uma das vigas ensaiadas.

\begin{tabular}{c|c}
\hline Viga & $\begin{array}{c}\text { Resistência do corpo } \\
\text { de prova cilíndrico } \\
\text { (MPa) }\end{array}$ \\
\hline BRS1 & 47 \\
BRS2 & 45 \\
BRC1 & 43 \\
BRC2 & 42 \\
\hline
\end{tabular}

Tabela 2 - Características mecânicas das barras utilizadas para reforço das vigas.

\begin{tabular}{c|cccc}
\hline $\begin{array}{c}\text { Tipo de } \\
\text { Barra }\end{array}$ & $\begin{array}{c}\text { Diâmetro } \\
(\mathrm{mm})\end{array}$ & $\begin{array}{c}\text { Resistência última } \\
\text { (MPa) }\end{array}$ & $\begin{array}{c}\text { Deformação } \\
\text { última }\end{array}$ & $\begin{array}{c}\text { Módulo de } \\
\text { Elasticidade (GPa) }\end{array}$ \\
\hline PRFC & 9,5 & 1676 & 0,0145 & 135,9 \\
Aço & 10 & $530^{*}$ & 0,0048 & 201 \\
Aço & 8 & $566^{*}$ & 0,0049 & 194 \\
Aço & 6 & $421^{*}$ & 0,0041 & 200 \\
\hline
\end{tabular}

* Tensão de escoamento do aço.

Tabela 3 - Parâmetros resultantes dos ensaios de flexão por quatro pontos.

\begin{tabular}{c|cccc}
\hline Viga & $\begin{array}{c}\text { Carga de } \\
\text { fissuração da viga } \\
(\mathrm{kN})\end{array}$ & $\begin{array}{c}\text { Carga de } \\
\text { ruptura da viga } \\
(\mathrm{kN})\end{array}$ & $\begin{array}{c}\text { Deflexão na } \\
\text { ruptura }(\mathrm{mm})\end{array}$ & Modo de falha \\
\hline BRS1 & 7,8 & 41,9 & 29,16 & escoamento do aço \\
BRS2 & 7,5 & 40,1 & 27,78 & escoamento do aço \\
BRC1 & 7,1 & 88,9 & 35,26 & compressão pelo cortante \\
BRC2 & 7,1 & 86,5 & 35,50 & compressão \\
\hline
\end{tabular}

Segundo os autores, a tensão última de tração na barra de PRFC foi de $1676 \mathrm{MPa}$, demonstrando comportamento linear elástico até a ruptura, ou seja, sem possuir patamar de plastificação como ocorre nas barras de aço convencionais. A energia de fratura do concreto foi calculada com base no trabalho de HILLERBORG et al (1976), o qual considera que a fissura inicia sua propagação no instante em que é atingida a tensão resistente de tração do concreto e a partir deste momento, a tensão segue decrescendo até atingir o valor zero conforme essa abertura aumenta até a largura de $w_{1}$. O método proposto por estes autores calcula a energia de fratura $\left(G_{f}\right)$ de acordo com:

$$
G_{f}=\int_{0}^{w_{1}} \sigma \cdot d w=\frac{f_{c t} \cdot w_{1}}{2}
$$


em que $f_{c t}$ é a resistência à tração do concreto. Neste trabalho foi considerado o valor de $f_{c t m}$ indicado pela NBR 6118:2014 para a análise da abertura de fissuras; $w_{1}$ é a largura da abertura de fissura cuja tensão atinge o valor zero. Segundo HILLERBORG et al (1976) esta largura é da ordem de 0,01 $\mathrm{mm}$ a 0,02 $\mathrm{mm}$. No presente trabalho foi utilizado o valor de 0,01 $\mathrm{mm}$ para este parâmetro.

Exemplificando o cálculo da energia de fratura para a viga BRC1:

$$
G_{f}=\frac{\left[0,3 \cdot(43)^{\frac{2}{3}} \cdot(1000)\right] \cdot 0,00001}{2}=18,4 \mathrm{~N} / \mathrm{m}
$$

A resistência à tração considerada para o concreto foi igual ao valor de $f_{c t m}$, indicado na NBR 6118:2014 para a análise da abertura de fissuras e calculado para a viga BRC1 de acordo com:

$$
f_{c t m}=0,3 \cdot f_{c k}^{2 / 3}=0,3 \times\left(43^{2 / 3}\right)=3,68 M P a
$$

O módulo de elasticidade $\left(E_{c S}\right)$ a ser considerado no concreto foi calculado de acordo com as indicações da NBR 6118:2014 e para a viga BRC1 apresentou-se como:

$$
E_{c i}=\alpha_{E} \cdot 5600 \cdot \sqrt{f_{c k}}
$$

Considerando o agregado graúdo utilizado sendo o granito, tem-se que $\alpha_{E}=1$.

$$
\begin{gathered}
E_{c i}=1 \times 5600 \cdot \sqrt{43}=36721,65 \mathrm{MPa} \rightarrow 36,7 \mathrm{GPa} \\
\alpha_{i}=0,8+0,2 \cdot \frac{f_{c k}}{80} \leq 1,0 \\
\alpha_{i}=0,8+0,2 \cdot \frac{43}{80}=0,9075 \\
E_{c s}=\alpha_{i} \cdot E_{c i}
\end{gathered}
$$




$$
E_{c s}=0,9075 \times 36,7=33,2 \mathrm{GPa}
$$

Segundo CERVENKA et al (2018), em relação ao concreto, o software utiliza um modelo constitutivo denominado por SBETA, o qual é uma abordagem de modelo de fissuração distribuída. O modelo SBETA inclui os seguintes efeitos para o comportamento do concreto:

- Comportamento não linear na compressão incluindo endurecimento e enfraquecimento;

- $\quad$ Fissuração do concreto por tração baseado na mecânica da fratura não linear;

- $\quad$ Critério de falha de resistência biaxial;

- Redução da resistência à compressão após a fissuração;

- $\quad$ Efeito de enrijecimento por tensão;

- Redução da rigidez de cisalhamento após a fissuração;

- Dois modelos de fissuração: direção fixa da fissura e direção rotacionada da fissura.

É considerada a aderência perfeita entre o concreto e o reforço e nenhum deslizamento dessa ligação pode ser modelado diretamente, exceto para aquele incluído inerentemente no enrijecimento por tensão. No entanto, a nível macro, pode ocorrer um deslizamento relativo da armadura em relação ao concreto ao longo de uma certa distância, se o concreto estiver fissurado ou esmagado. Isso corresponde a um mecanismo real de ruptura da aderência no caso das barras com nervuras. A Figura 2 apresenta a lei de tensão-deformação adotada pelo Atena para o concreto e a lei biaxial de falha para este mesmo material. 

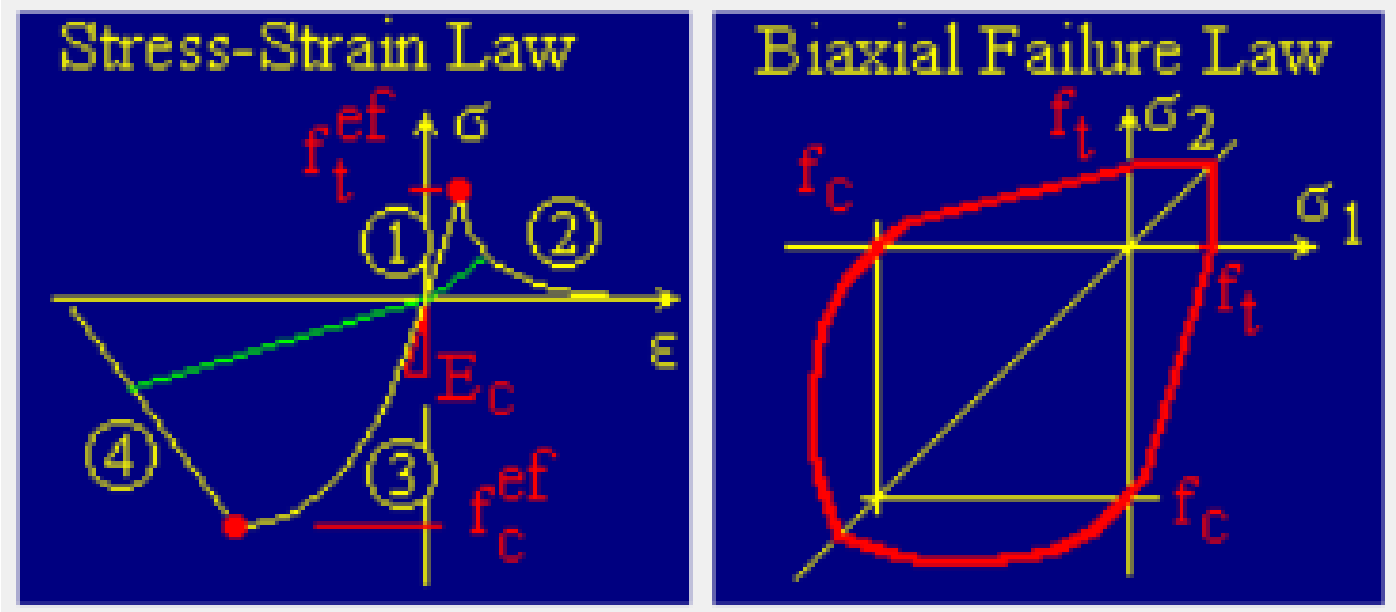

Figura 2 - Lei uniaxial de tensão-deformação para o concreto e lei biaxial de falha para esse mesmo material.

Os números presentes no diagrama de tensão-deformação da Figura 2 são utilizados para indicar os diferentes trechos do diagrama de tensão-deformação do concreto. O comportamento do concreto sob tração anteriormente à fissuração é considerado linear elástico, sendo $E_{c}$ o módulo de elasticidade inicial e $f_{t}^{e f}$ a resistência de tração efetiva derivada da função biaxial de falha. Para a tensão após a fissuração o Atena trabalha com dois modelos, sendo um modelo de fissura fictício baseado em uma lei de abertura de fissura e energia de fratura e o outro uma relação tensão-deformação em um ponto do material. Esta segunda formulação não é adequada para casos normais de propagação de fissuras no concreto e deve ser usada apenas em alguns casos especiais. Em relação à compressão antes do pico de tensão, o Atena adota a fórmula recomendada pelo CEB-FIP Model Code 90 para o trecho ascendente da curva de tensão-deformação na parte de compressão. Já para a compressão após o pico de tensão, a lei de enfraquecimento na compressão é linearmente decrescente. Existem dois modelos de suavização da deformação na compressão, um baseado na energia dissipada e outro baseado na suavização local da deformação.

A lei constitutiva referente às barras de polímero reforçado com fibras de carbono submetidas à tração está apresentada na Figura 3 e trata-se de um diagrama de tensãodeformação linear, considerando o comportamento linear elástico deste material até a ruptura. 


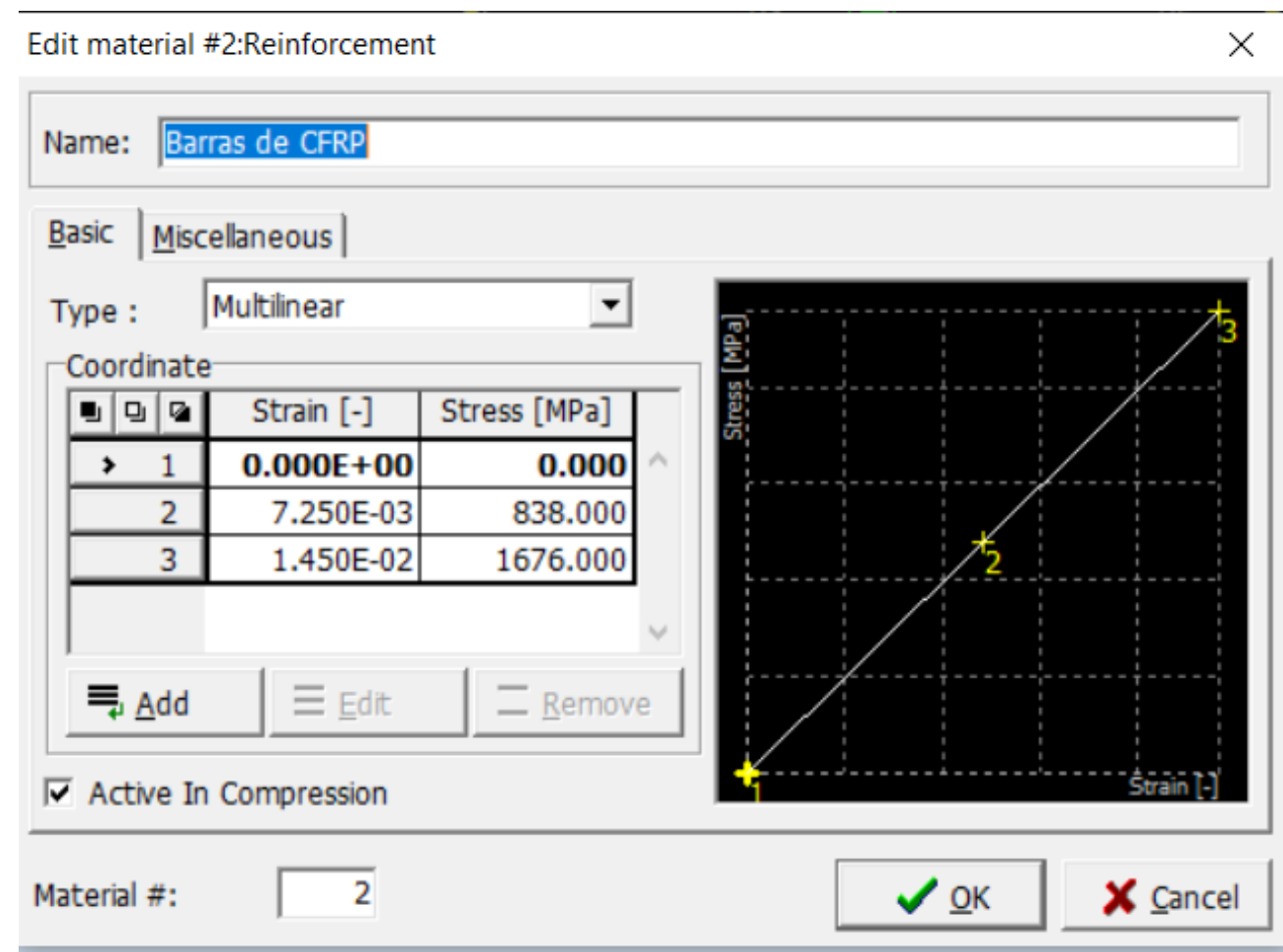

Figura 3 - Diagrama de tensão-deformação para as barras de PRFC.

As leis constitutivas referentes às barras de aço com diâmetro de $10 \mathrm{~mm}, 8 \mathrm{~mm}$ e 6 mm estão apresentadas na Figura 4, na Figura 5 e na Figura 6 respectivamente, tratando-se de um diagrama de tensão-deformação bilinear com patamar plástico, como é considerado na NBR 6118:2014. As tensões de escoamento do aço e seu módulo de elasticidade foram aquelas encontradas por RAFI et al (2007) para a realização do ensaio da viga à flexão. 


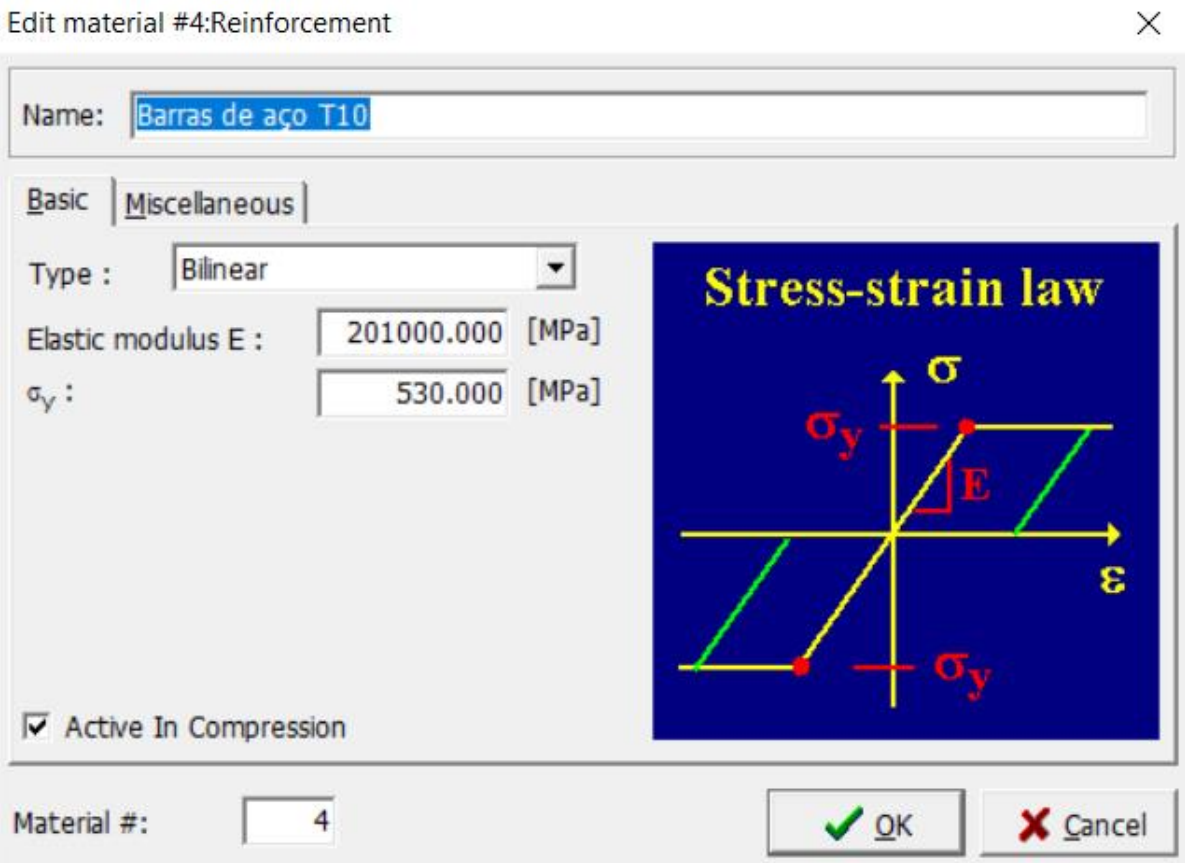

Figura 4 - Diagrama de tensão-deformação paras as barras de aço com diâmetro de $10 \mathrm{~mm}$.

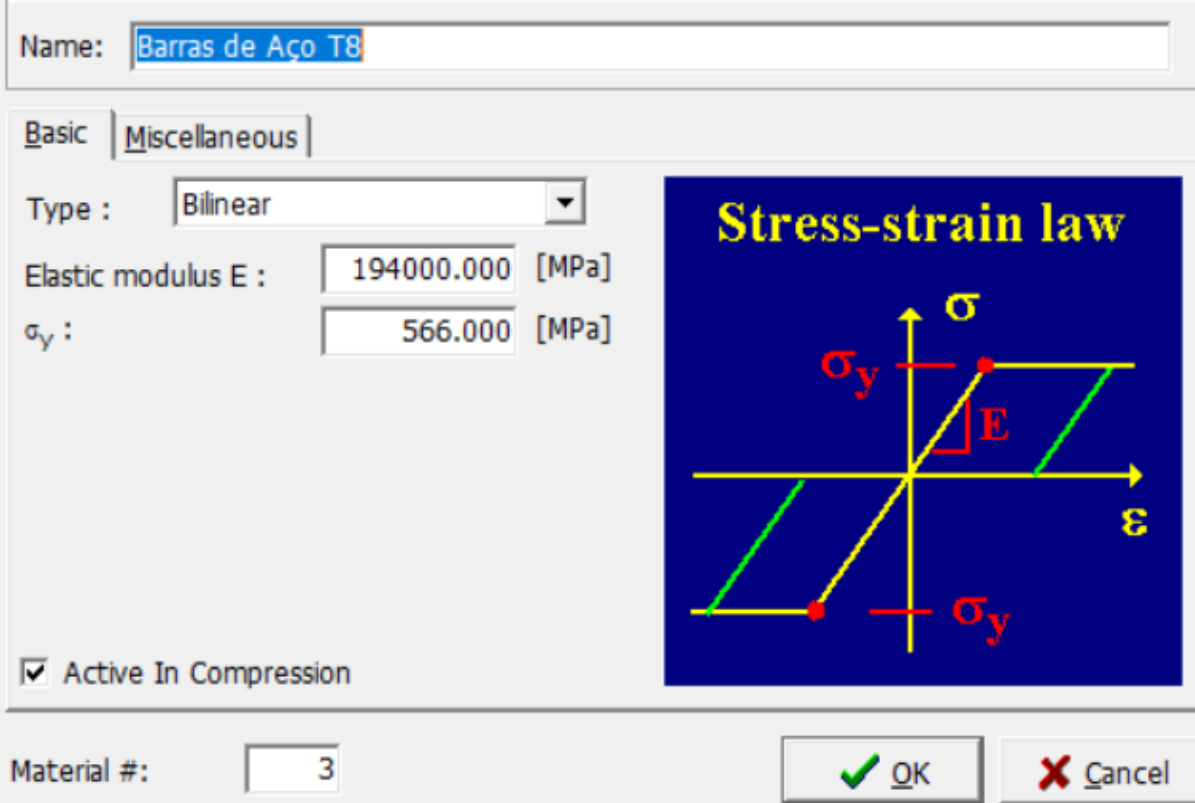

Figura 5 - Diagrama de tensão-deformação paras as barras de aço com diâmetro de 8 mm. 


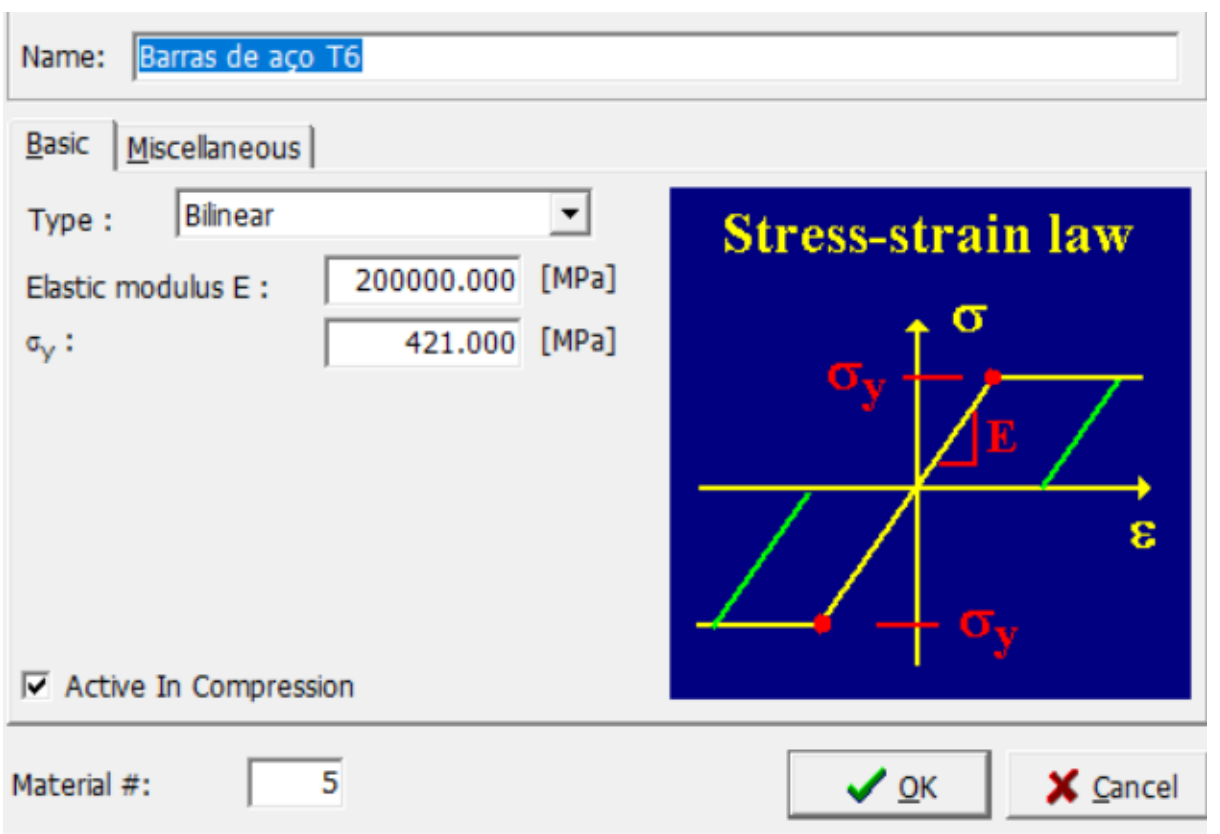

Figura 6 - Diagrama de tensão-deformação paras as barras de aço com diâmetro de $6 \mathrm{~mm}$.

A viga apresentada na Figura 1 foi modelada no software Atena como tentativa de reproduzir através de um modelo de elementos finitos com análise não linear o mesmo ensaio à flexão realizado por RAFI et al (2007) em laboratório. A partir da Figura 1 é possível verificar que o carregamento é aplicado em dois pontos distantes $80 \mathrm{~cm}$ das faces laterais da viga. No entanto, para evitar que fosse inserido no modelo locais com elevadas concentrações de tensões decorrentes de altas cargas pontuais, esses locais de aplicação do carregamento foram divididos em três pontos de aplicação ao longo de $10 \mathrm{~cm}$.

No trabalho de RAFI et al (2007) os autores realizaram o teste à flexão submetendo as vigas BRC1 e BRC2 a incrementos de carga de $5 \mathrm{kN}$, ou seja, 2,5 kN em cada um dos dois pontos de contato com a viga. Esses 2,5 kN foram então divididos em três carregamentos de 0,833 kN aplicados em três pontos ao longo de $10 \mathrm{~cm}$. O Atena trabalha com a unidade de mega Newton (MN) para a aplicação de cargas, logo, realizando-se a conversão de unidades, tem-se que $0,833 \mathrm{kN}=8,33 \times 10^{-4} \mathrm{MN}$. A Figura 7 apresenta o incremento de carregamento que é aplicado nas vigas BRC1 e BRC2.

Já para as vigas BRS1 e BRS2 os autores utilizaram incrementos de cargas de 2,5 $\mathrm{kN}$, ou seja, 1,25 kN em cada um dos dois pontos de contato com a viga. Esses 1,25 kN foram então divididos em três carregamentos de $4,17 \times 10^{-4} M N$ aplicados em três pontos ao longo de $10 \mathrm{~cm}$. A Figura 8 apresenta o incremento de carregamento que é aplicado nas vigas BRS1 e BRS2. 


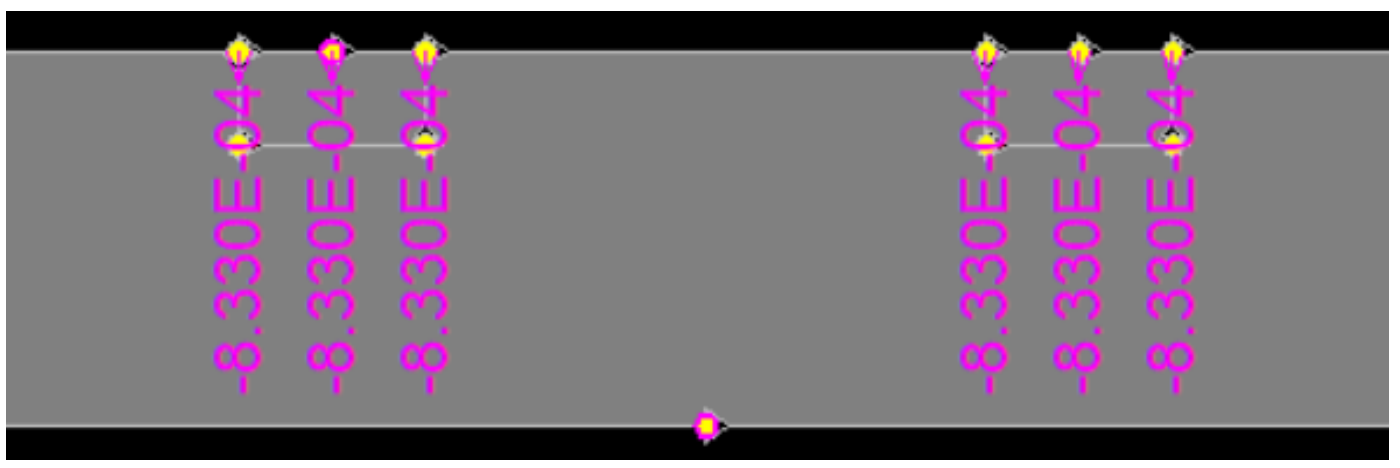

Figura 7 - Incrementos de carga aplicados nas vigas BRC1 e BRC2.

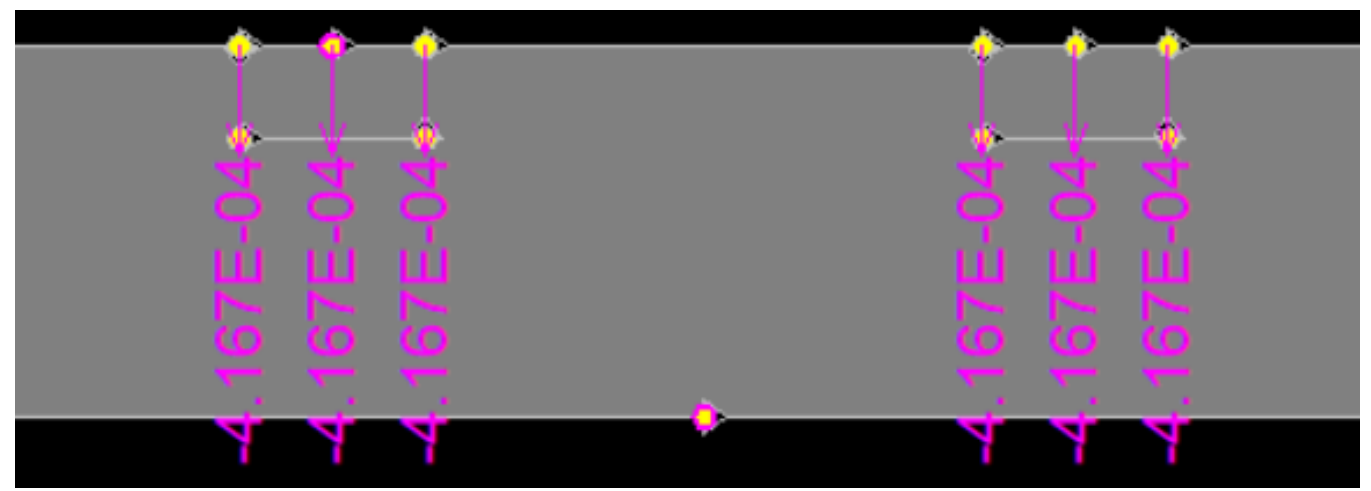

Figura 8 - Incrementos de carga aplicados nas vigas BRS1 e BRS2.

Durante a modelagem da viga, foram inseridos três pontos de monitoramento, sendo o primeiro para monitorar os valores de incremento de cargas, o segundo para monitorar reações verticais de apoio e o terceiro para monitorar deslocamentos verticais da viga. O primeiro ponto de monitoramento está localizado na face superior da viga à distância de $80,0 \mathrm{~cm}$ em relação à sua face lateral esquerda, o segundo ponto de monitoramento foi inserido no apoio esquerdo e o terceiro ponto de monitoramento na face inferior da viga no meio do vão. A Figura 9 apresenta a configuração de armaduras utilizada em todas as vigas, os apoios e os pontos de monitoramento.

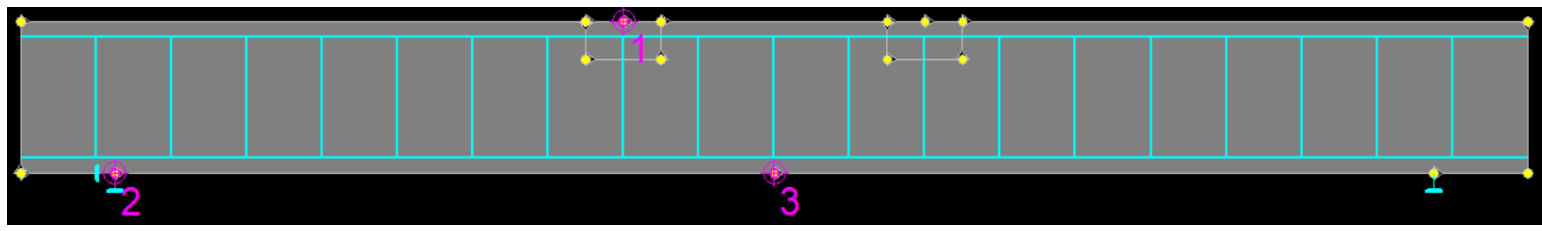

Figura 9 - Configuração das armaduras utilizadas nas vigas, apoios e pontos de monitoramento.

Como é possível observar na Figura 7, na Figura 8 e na Figura 9, foram definidas duas regiões localizadas desde os pontos de aplicação das cargas até $5 \mathrm{~cm}$ abaixo destes 
pontos. Essas regiões têm por objetivo estabelecer uma configuração de malha de elementos finitos melhor discretizada nas proximidades de aplicação das cargas. As malhas de tais regiões foram definidas com espaçamento de $2 \mathrm{~cm}$ entre os nós, enquanto no restante da viga esse espaçamento foi de $5 \mathrm{~cm}$. Os tipos de elementos utilizados na definição das malhas de elementos finitos foram a mistura entre elementos triangulares e quadriláteros.

3.1.

\section{Modelagem da viga BRC1}

A viga BRC1 foi calculada utilizando os parâmetros apresentados na Figura 10. É importante ressaltar que para a realização deste trabalho foi utilizada uma versão demo do software Atena e dessa maneira não há uma quantidade grande de opções para combinação de parâmetros. A configuração apresentada foi a que obteve resultados mais coerentes com aqueles decorrentes dos experimentos.

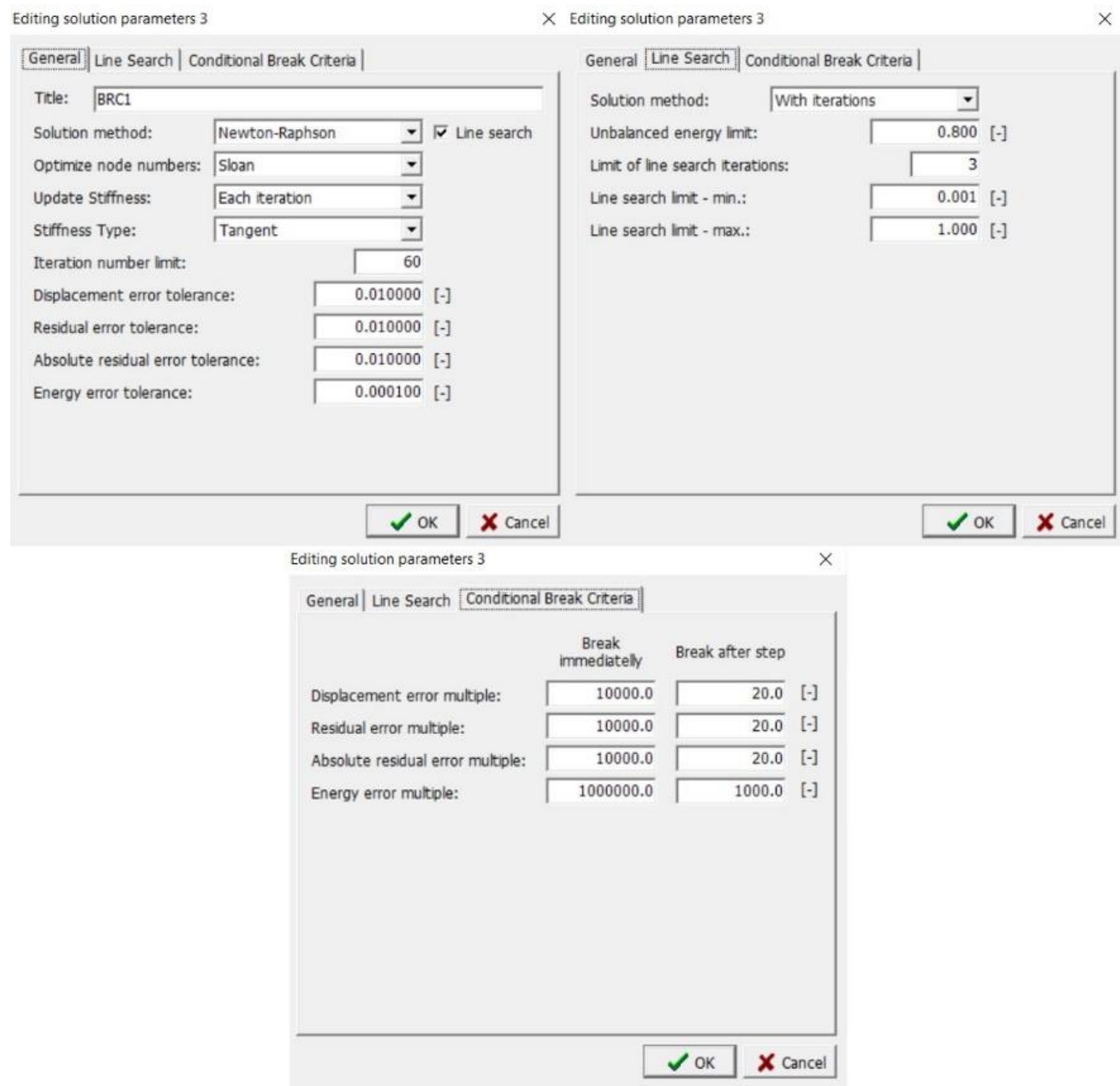

Figura 10 - Parâmetros de cálculo para a viga BRC1. 
Como é possível observar na Tabela 3, a carga de ruptura constatada na viga BRC1 durante o ensaio realizado por RAFI et al (2007) foi de 88,9 kN. Dessa maneira, a análise no Atena foi realizada para o $18^{\circ}$ incremento de carga, o qual inseriu na viga um total de 90 kN. A Figura 11 apresenta os resultados referentes à abertura de fissura, tensão principal mínima no concreto, tensão principal máxima nas armaduras e reações verticais de apoio para o incremento de carga de 90 kN obtidos na simulação da viga BRC1.
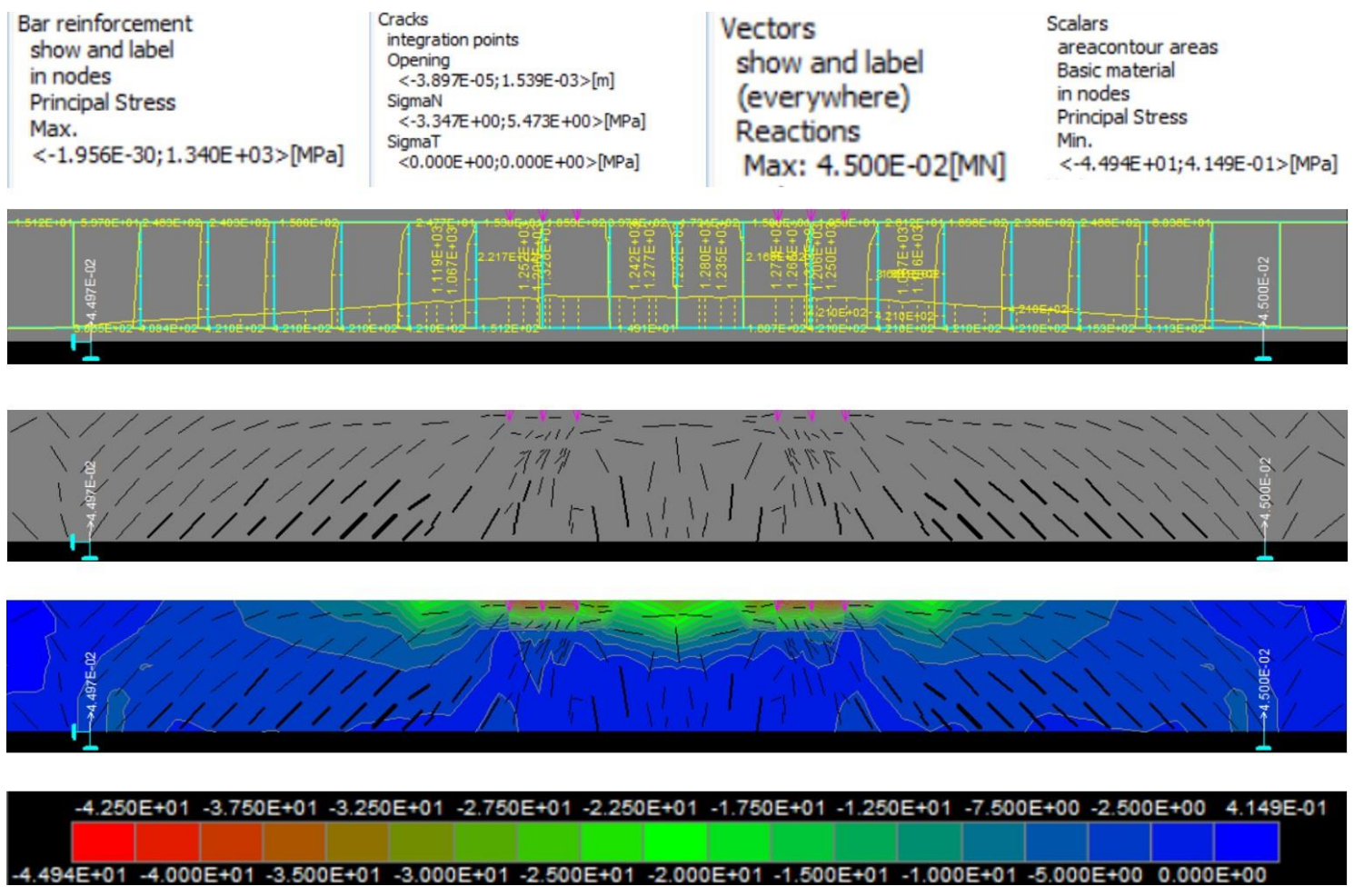

Figura 11 - Resultados referentes à abertura de fissura, tensão principal mínima no concreto, tensão principal máxima nas armaduras e reações verticais de apoio para o incremento de carga de 90 kN obtidos na simulação da viga BRC1.

A carga de fissuração calculada para a viga BRC1 é decorrente do 20 incremento de carga, ou seja, 10 kN e está apresentada na Figura 12 com suas respectivas reações verticais de apoio e a ilustração das fissuras iniciais decorrentes desta carga.

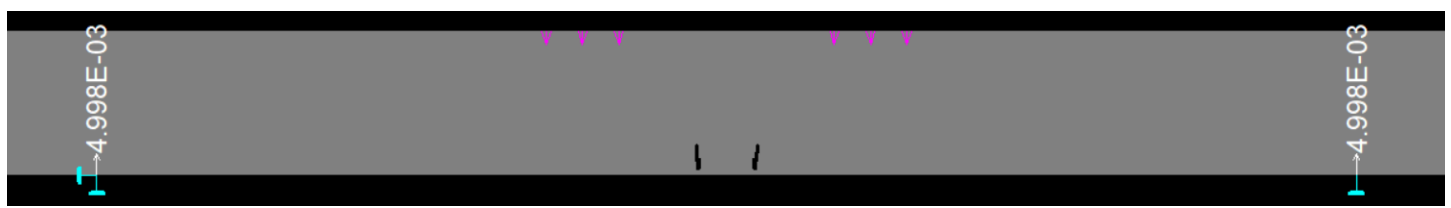

Figura 12 - Fissuras iniciais decorrente do segundo incremento de carga e respectivas reações verticais de apoio na unidade de $\mathrm{MN}$.

O deslocamento vertical máximo da viga calculado para o carregamento de $90 \mathrm{kN}$ foi obtido através do gráfico de força aplicada-deslocamento. Esse deslocamento foi 
obtido pelo ponto de monitoramento 3 e é importante ressaltar que no diagrama em questão, para se obter o valor total da força que está sendo aplicada em um dado incremento é necessário multiplicar o valor mostrado no gráfico por 6 . Isso é necessário porque o ponto de monitoramento 1 está situado em um dos 6 pontos onde ocorre a aplicação das cargas. Logo, o valor de força demonstrado no diagrama que resulta em 90 kN de carregamento total é $1,5 \times 10^{-2} M N$. O diagrama em questão está apresentado na Figura 13.

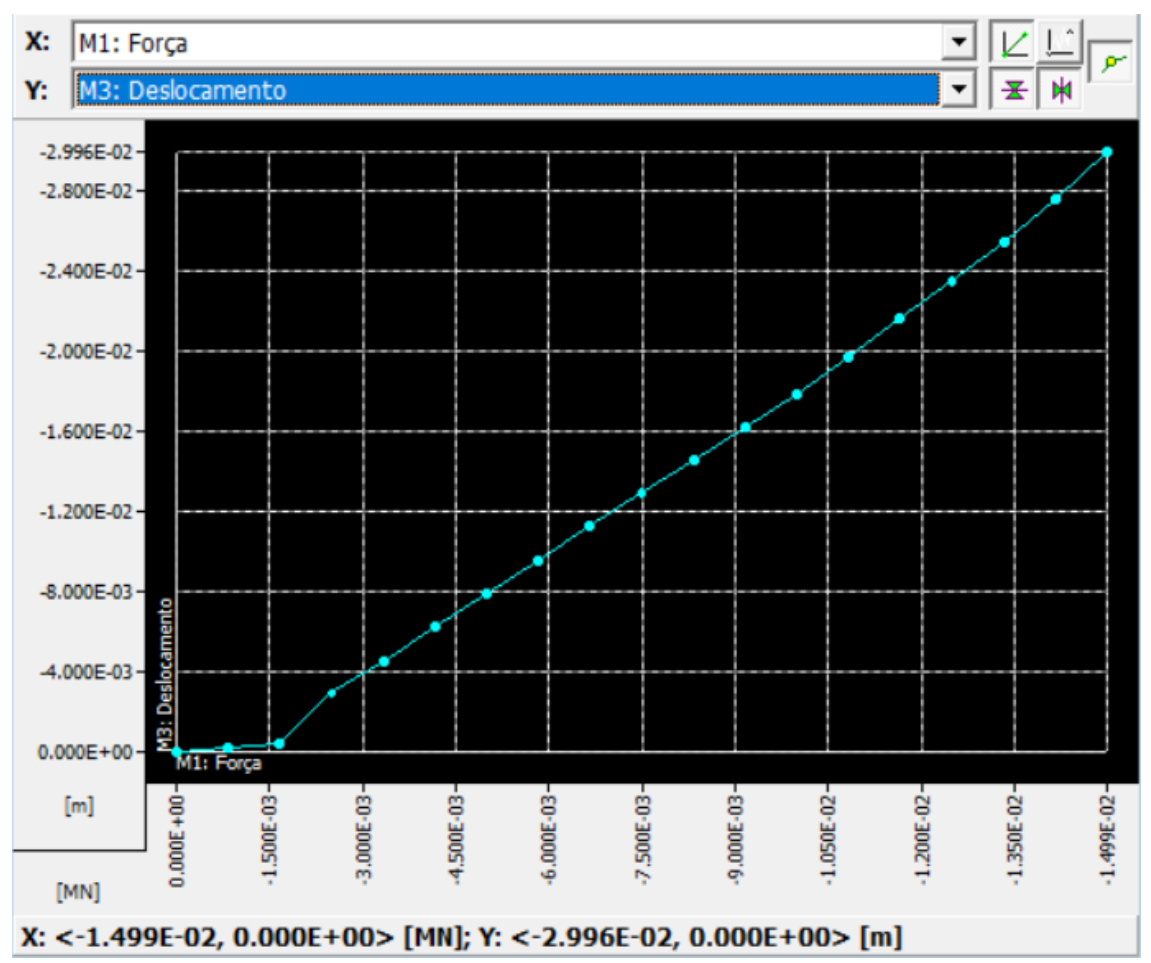

Figura 13 - Diagrama de força aplicada-deslocamento vertical para a viga BRC1.

\section{2.}

\section{Modelagem da viga BRC2}

A viga BRC2 foi calculada utilizando os parâmetros apresentados na Figura 14. 
Editing solution parameters 3

$\times$ Editing solution parameters 3

$\times$

General | Line Search | Conditional Break Criteria |

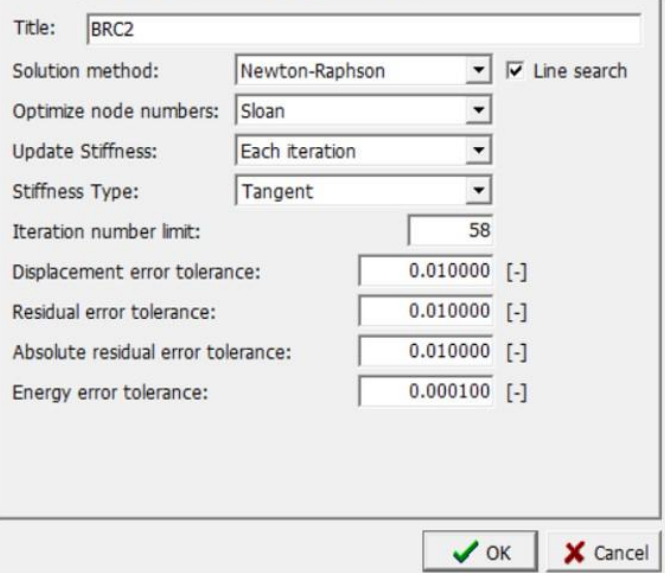

Editing solution parameters 3

General| Line Search Conditional Break Criteria

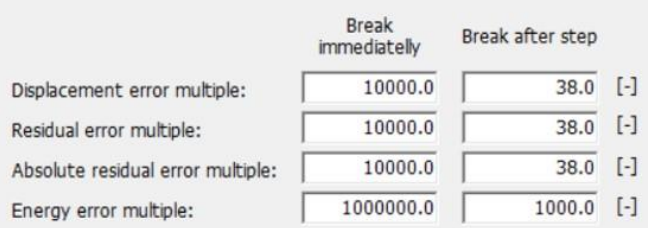

Energy error multiple:

General Line Search Conditional Break Criteria

Solution method: With iterations

Unbalanced energy limit:

Limit of line search iterations:

Line search limit - $\min$.:

Line search limit - max.:

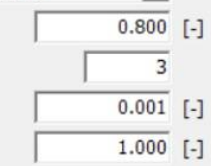

OK $\mathbf{X}$ cancel

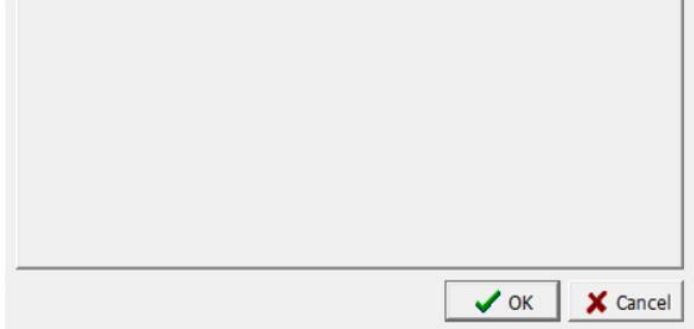

Figura 14 - Parâmetros de cálculo para a viga BRC2.

A carga de ruptura constatada na viga BRC2 durante o ensaio realizado por RAFI et al (2007) foi de $86,5 \mathrm{kN}$. Dessa maneira, a análise no Atena foi realizada para o $17^{\circ}$ incremento de carga, o qual inseriu na viga um total de $85 \mathrm{kN}$. A Figura 15 apresenta os resultados referentes à abertura de fissura, tensão principal mínima no concreto, tensão principal máxima nas armaduras e reações verticais de apoio para o incremento de carga de 85 kN obtidos na simulação da viga BRC2. 

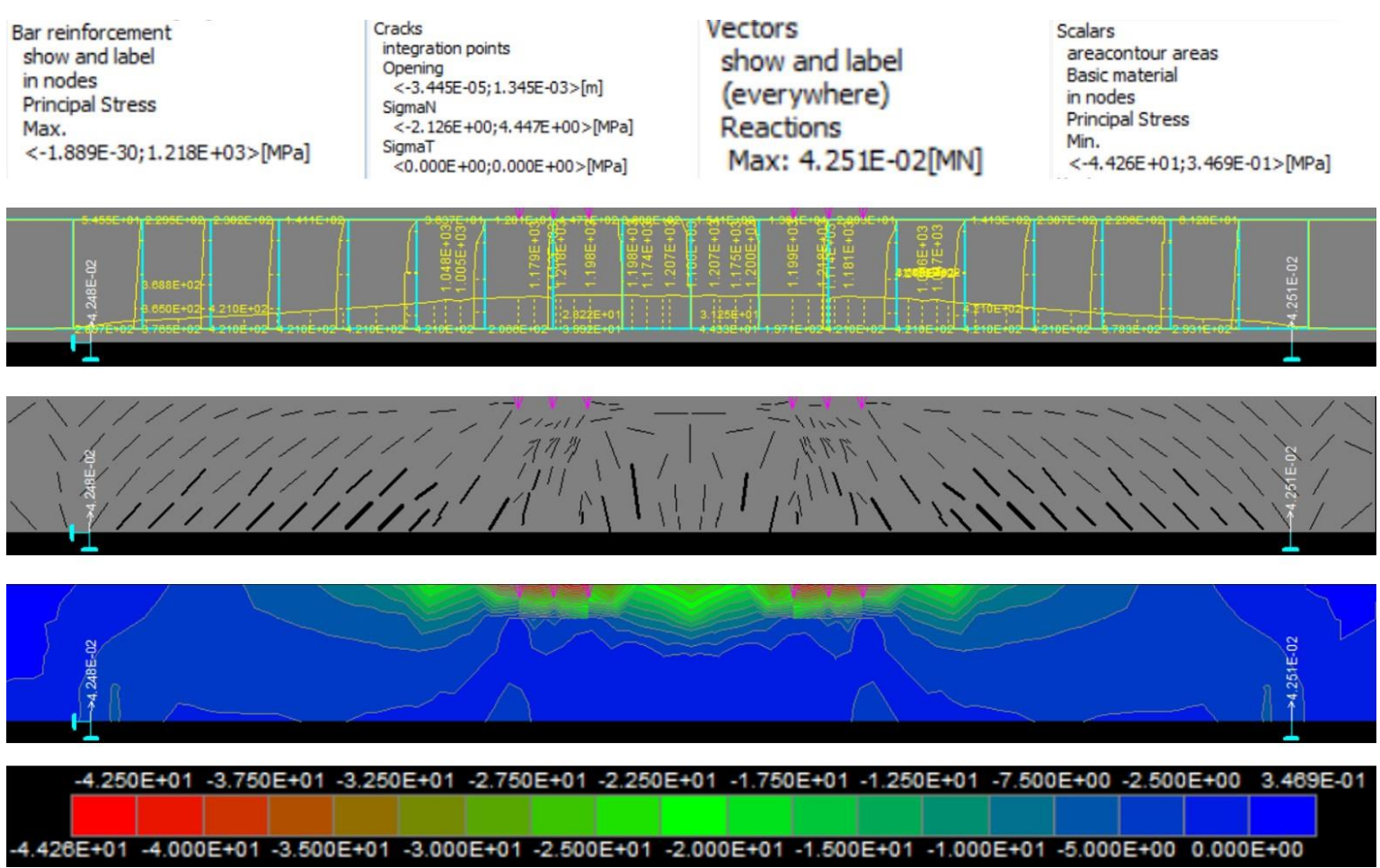

Figura 15 - Resultados referentes à abertura de fissura, tensão principal mínima no concreto, tensão principal máxima nas armaduras e reações verticais de apoio para o incremento de carga de 85 kN obtidos na simulação da viga BRC2.

Assim como ocorreu para a viga BRC1, a carga de fissuração calculada para a viga BRC2 também é decorrente do 20 incremento de carga, ou seja, $10 \mathrm{kN}$. O deslocamento vertical máximo da viga BRC2 calculado para o carregamento de $85 \mathrm{kN}$ foi obtido através do gráfico de força aplicada-deslocamento, o qual está apresentado na Figura 16. Para o carregamento total de $85 \mathrm{kN}$, deve ser observado o valor de força referente a $1,425 \times 10^{-2} \mathrm{MN}$. 


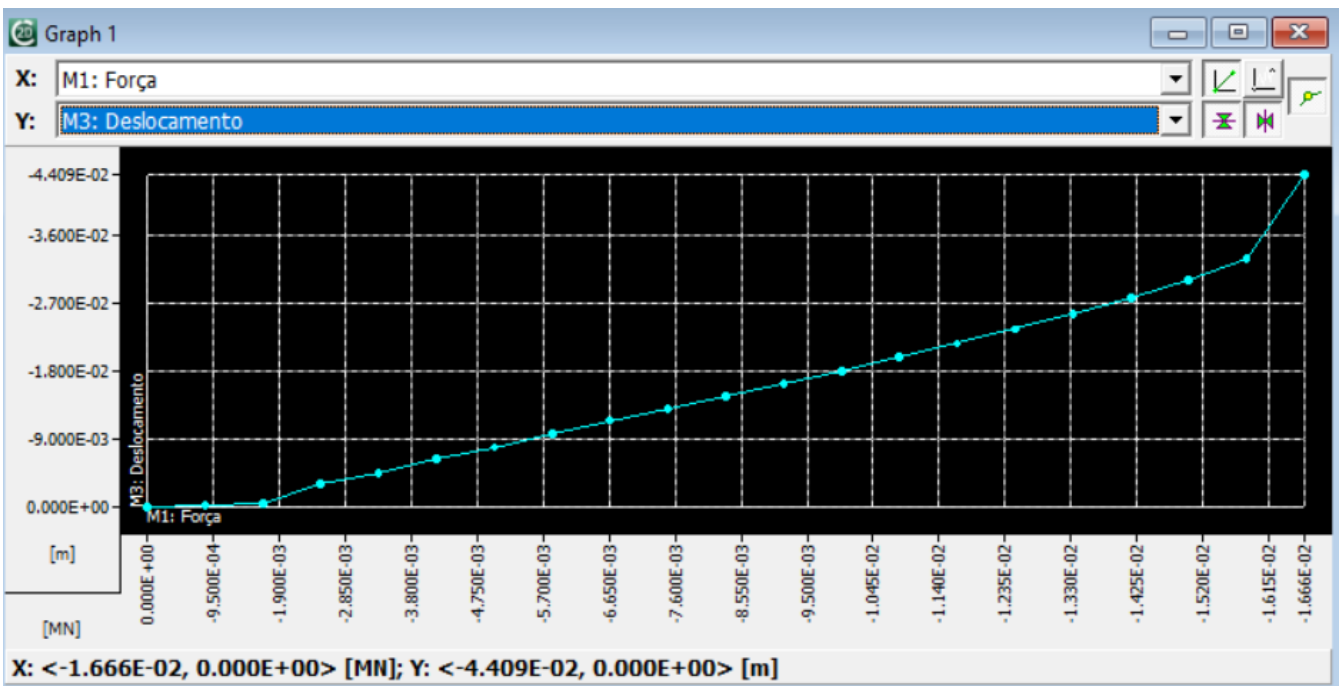

Figura 16- Diagrama de força aplicada-deslocamento vertical para a viga BRC2.

\section{3.}

\section{Modelagem da viga BRS1}

A viga BRS1 foi calculada utilizando os mesmos parâmetros de cálculo utilizados na viga BRC1. A carga de ruptura constatada na viga BRS1 durante o ensaio realizado por RAFI et al (2007) foi de 41,9 kN. Dessa maneira, a análise no Atena foi realizada para o $17^{\circ}$ incremento de carga, o qual inseriu na viga um total de $42,5 \mathrm{kN}$. A Figura 17 apresenta os resultados referentes à abertura de fissura, tensão principal mínima no concreto, tensão principal máxima nas armaduras e reações verticais de apoio para o incremento de carga de 42,5 kN obtidos na simulação da viga BRS1. 

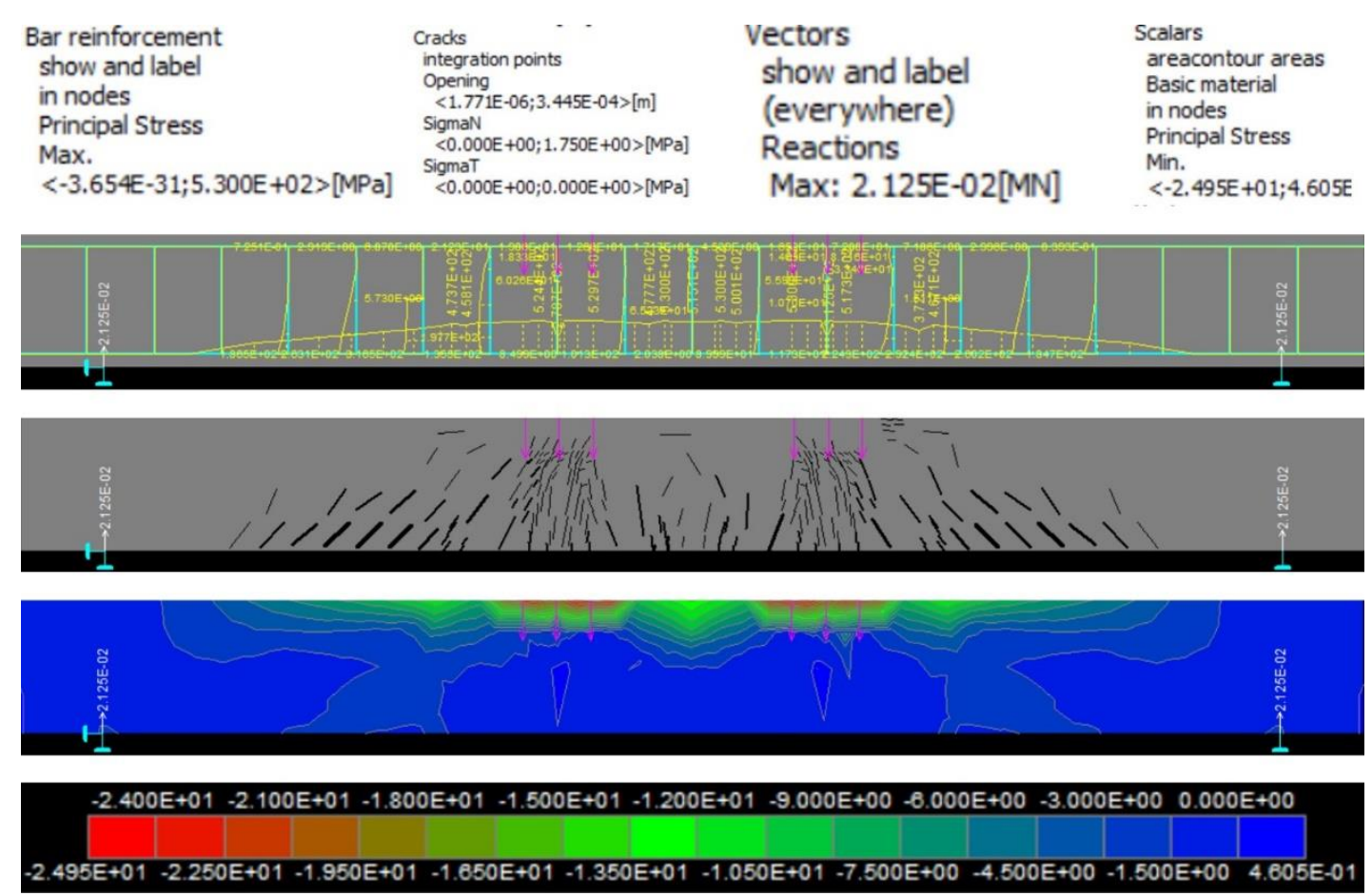

Figura 17 - Resultados referentes à abertura de fissura, tensão principal mínima no concreto, tensão principal máxima nas armaduras e reações verticais de apoio para o incremento de carga de 42,5 kN obtidos na simulação da viga BRS1.

A carga de fissuração calculada para a viga BRS1 é decorrente do 50 incremento de carga, ou seja, 12,5 kN e está apresentada na Figura 18 com suas respectivas reações verticais de apoio e a ilustração das fissuras iniciais decorrentes desta carga.

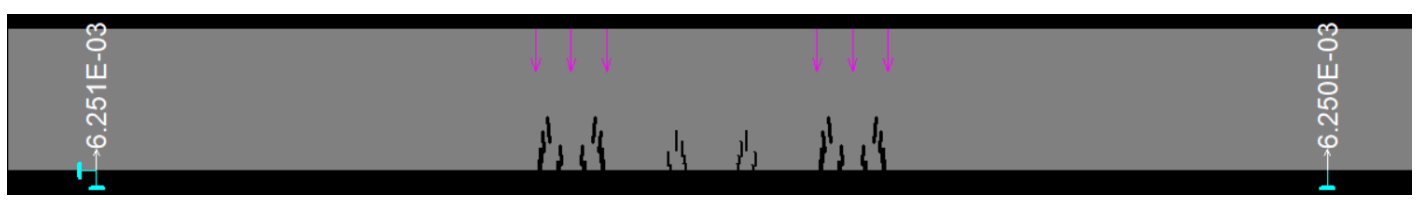

Figura 18 - Fissuras iniciais decorrente do quinto incremento de carga e respectivas reações verticais de apoio na unidade de $\mathrm{MN}$.

O deslocamento vertical máximo da viga BRS1 calculado para o carregamento de 42,5 kN foi obtido através do gráfico de força aplicada-deslocamento, o qual está apresentado na Figura 19. Para o carregamento total de 42,5 kN, deve ser observado o valor de força referente a 7, $083 \times 10^{-3} \mathrm{MN}$. 


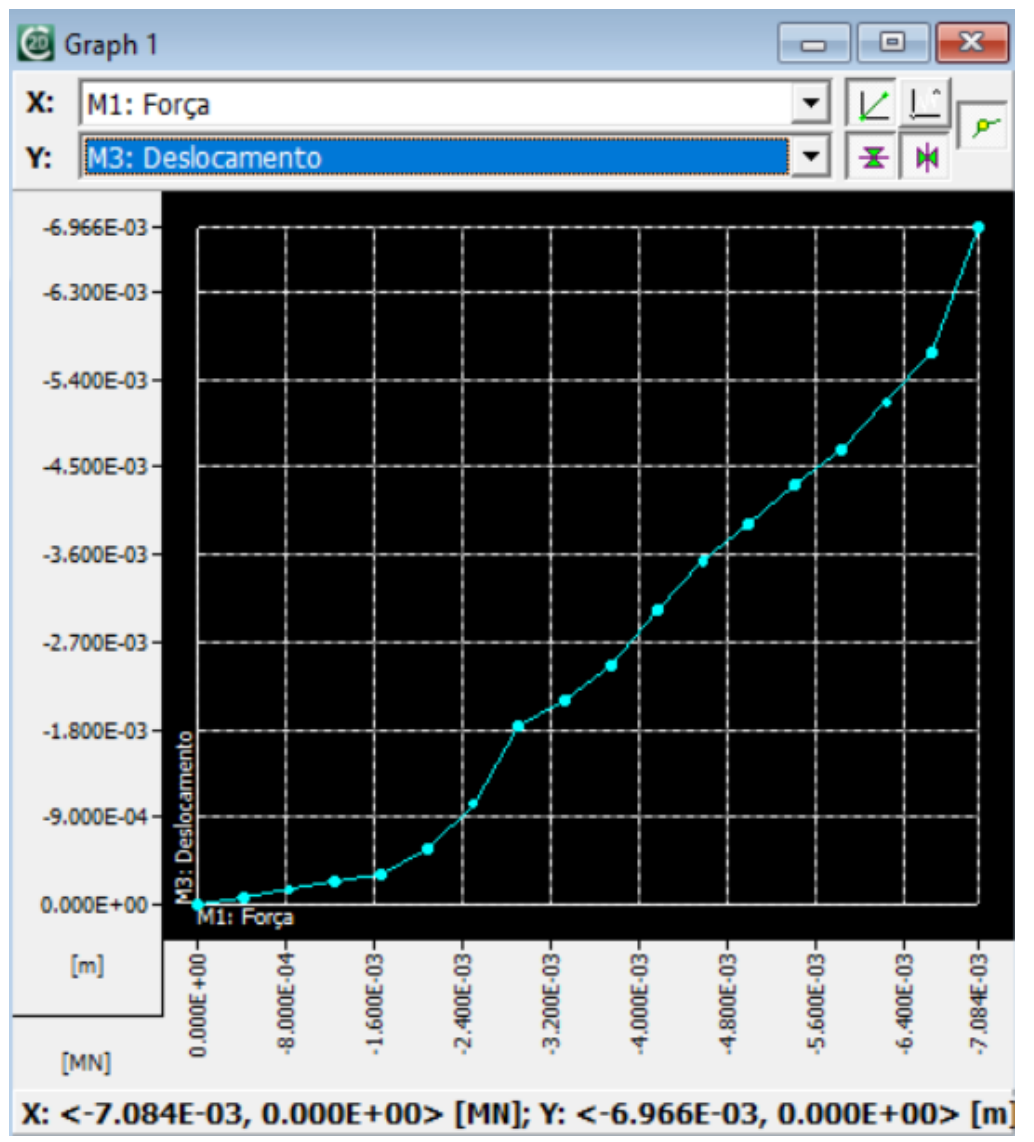

Figura 19 - Diagrama de força aplicada-deslocamento vertical para a viga BRS1.

\section{4.}

\section{Modelagem da viga BRS2}

A viga BRS2 foi calculada utilizando os mesmos parâmetros de cálculo utilizados nas vigas BRC1 e BRS1. A carga de ruptura constatada na viga BRS2 durante o ensaio realizado por RAFI et al (2007) foi de 40,1 kN. Dessa maneira, a análise no Atena foi realizada para o $16^{\circ}$ incremento de carga, o qual inseriu na viga um total de $40,0 \mathrm{kN}$. A Figura 20 apresenta os resultados referentes à abertura de fissura, tensão principal mínima no concreto, tensão principal máxima nas armaduras e reações verticais de apoio para o incremento de carga de 40,0 kN obtidos na simulação da viga BRS2. 

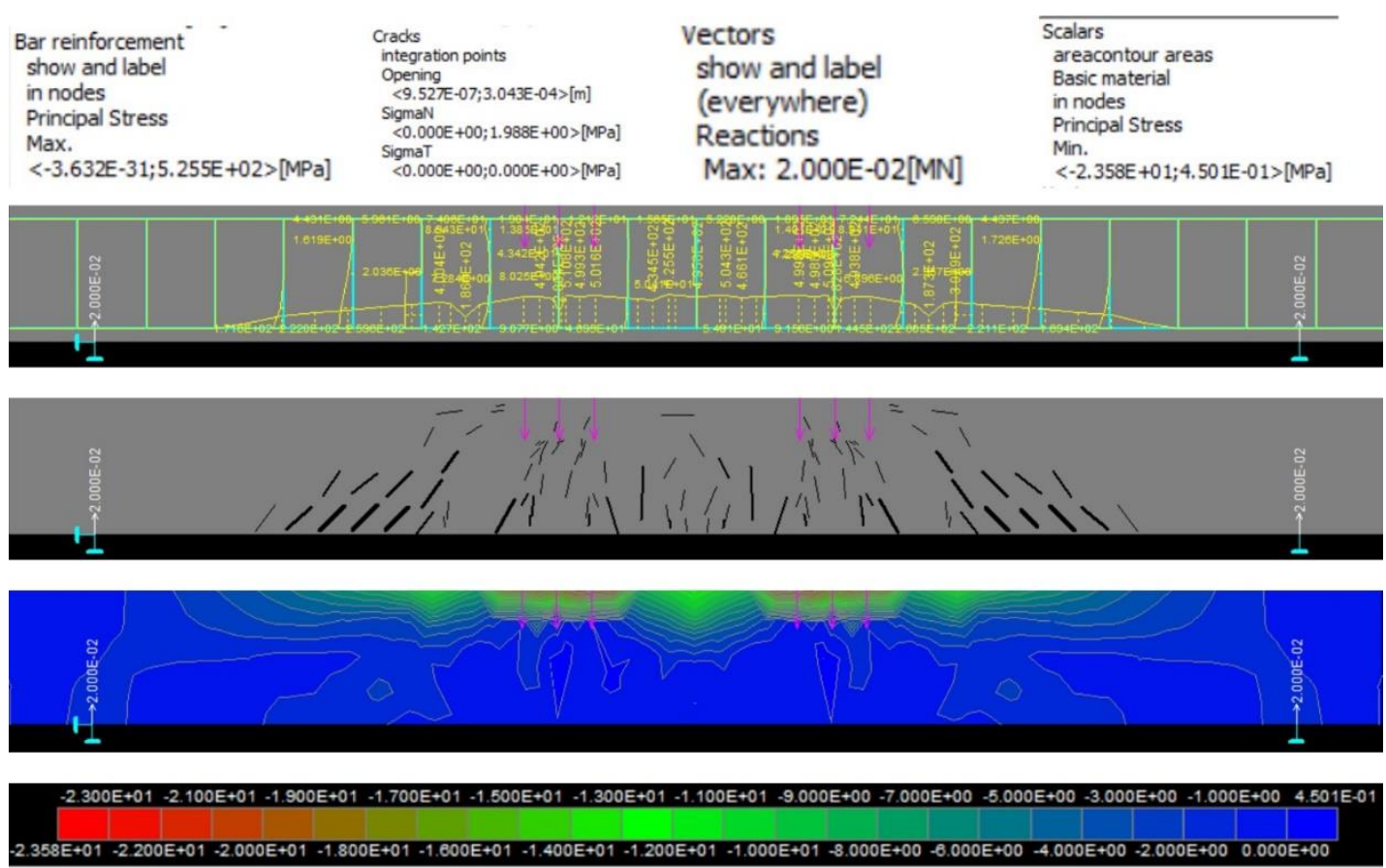

Figura 20 - Resultados referentes à abertura de fissura, tensão principal mínima no concreto, tensão principal máxima nas armaduras e reações verticais de apoio para o incremento de carga de $\mathbf{4 0} \mathbf{k N}$ obtidos na simulação da viga BRS2.

Assim como ocorreu para a viga BRS1, a carga de fissuração calculada para a viga BRS2 também é decorrente do 5 o incremento de carga, ou seja, $12,5 \mathrm{kN}$. O deslocamento vertical máximo da viga BRS2 calculado para o carregamento de $40,0 \mathrm{kN}$ foi obtido através do gráfico de força aplicada-deslocamento, o qual está apresentado na Figura 21. Para o carregamento total de $40,0 \mathrm{kN}$, deve ser observado o valor de força referente a $6,667 \times 10^{-3} \mathrm{MN}$. 


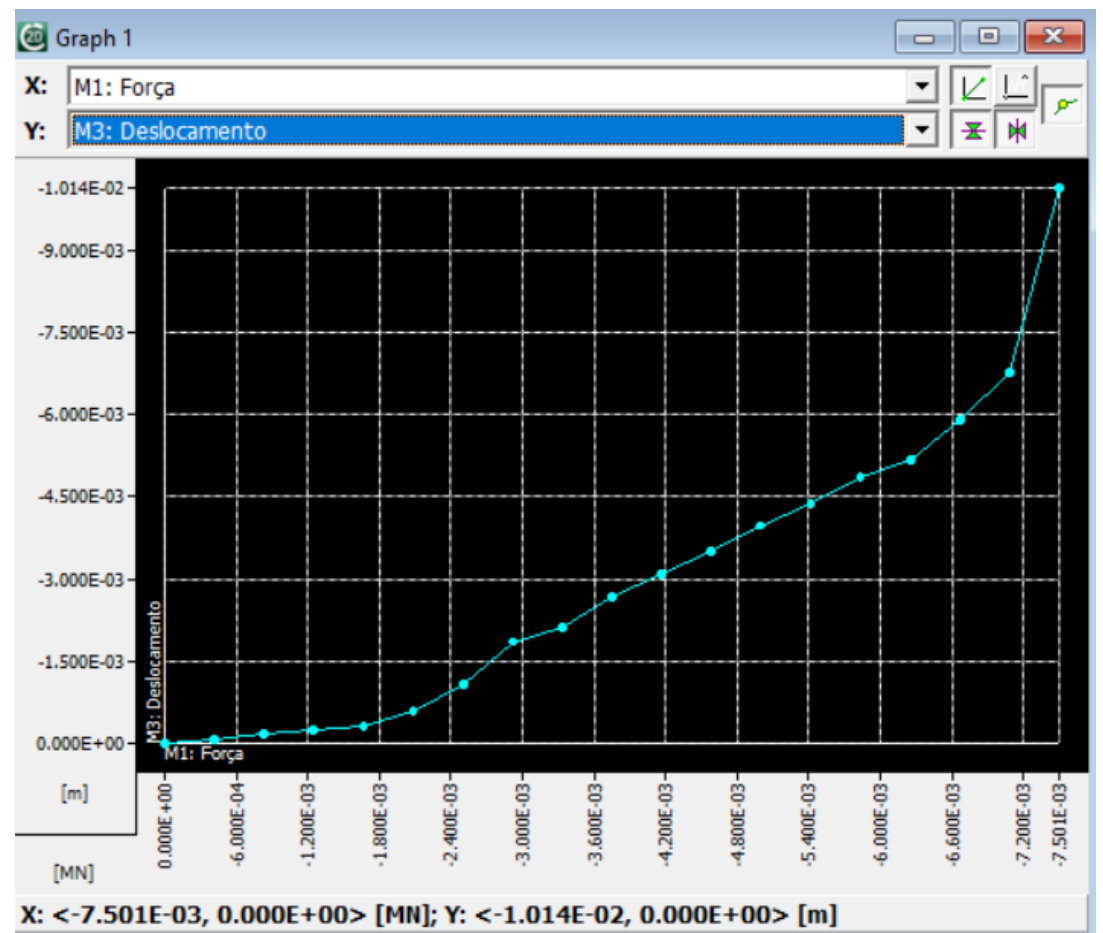

Figura 21 - Diagrama de força aplicada-deslocamento vertical para a viga BRS2.

Na próxima seção serão analisados os resultados obtidos nas simulações realizadas no Atena em comparação com aqueles decorrentes dos experimentos de Rafi et al (2007).

\section{5.}

\section{Comparação dos resultados}

A Tabela 4 apresenta o resumo dos resultados obtidos pelas análises das vigas realizadas no Atena.

Tabela 4 - Resultados obtidos pelas análises das vigas realizadas no Atena.

\begin{tabular}{l|c|c|c|c|c}
\hline Viga & $\begin{array}{c}\text { Carga de } \\
\text { fissuração } \\
\text { da viga no } \\
\text { Atena (kN) }\end{array}$ & $\begin{array}{c}\text { Carga na } \\
\text { viga } \\
\text { analisada } \\
\text { no Atena } \\
(\mathrm{kN})\end{array}$ & $\begin{array}{c}\text { Deflexão na } \\
\text { carga } \\
\text { analisada } \\
\text { no Atena } \\
(\mathrm{mm})\end{array}$ & $\begin{array}{c}\text { Tensão máxima } \\
\text { na armadura } \\
\text { longitudinal de } \\
\text { tração no Atena } \\
(\mathrm{MPa})\end{array}$ & $\begin{array}{c}\text { Modo de falha no } \\
\text { Atena }\end{array}$ \\
\hline BRS1 & 12,5 & 42,5 & 7,0 & 530 & escoamento do aço \\
BRS2 & 12,5 & 40 & 6,0 & 525,5 & escoamento do aço \\
BRC1 & 10 & 90 & 29,0 & 1340 & Não identificado \\
BRC2 & 10 & 85 & 27,0 & 1218 & Não identificado \\
\hline
\end{tabular}


A Figura 22 apresenta a curva de carga-deflexão no meio do vão obtida paras as vigas em questão durante os experimentos realizados por RAFI et al (2007).

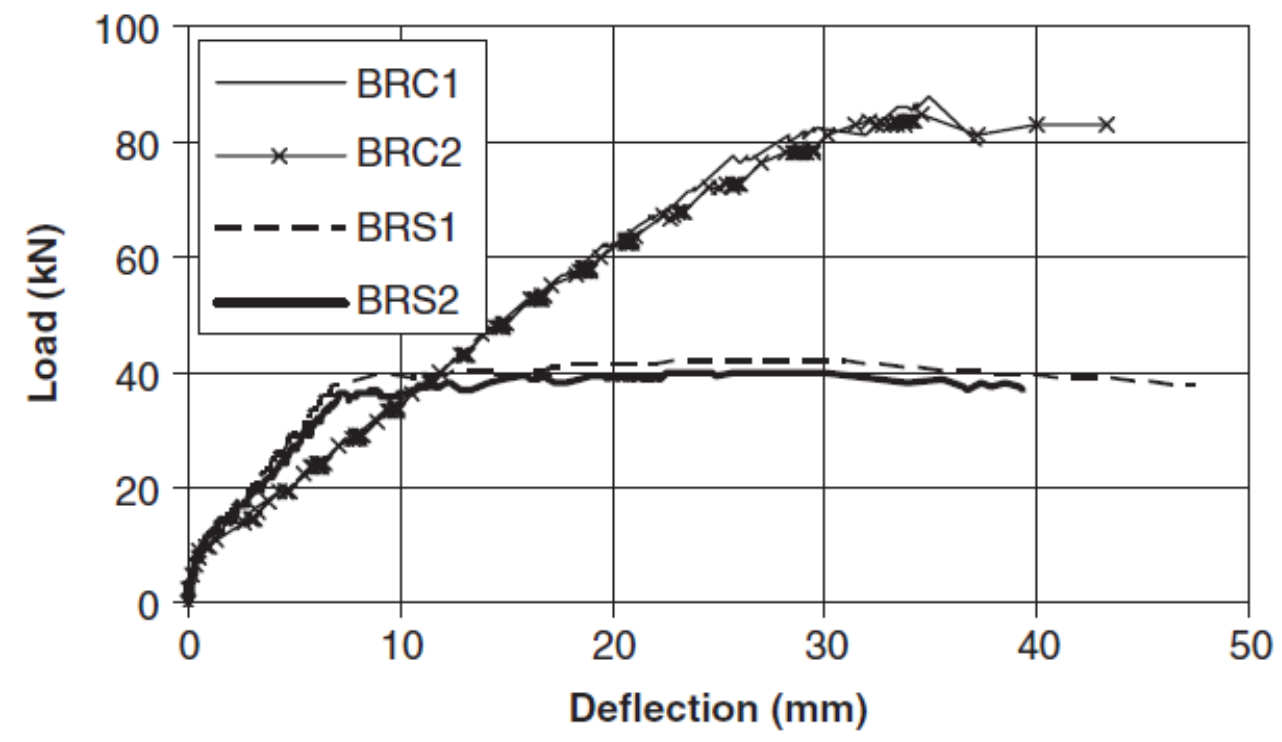

Figura 22 - Curva de carga-deflexão no meio do vão obtida paras as vigas em questão durante os experimentos realizados por RAFI et al (2007).

Analisando os resultados é possível perceber que em relação às cargas que levaram as vigas à fissuração, para os modelos simulados no Atena referentes às BRS1 e BRS2, essa carga apresentou-se na faixa de mesma ordem de grandeza daquela obtida por RAFI et al (2007) durante os ensaios de laboratório. O mesmo ocorreu para as vigas BRC1 e BRC2.

Para a deflexão máxima registrada nas vigas, os modelos referentes às vigas BRS1 e BRS2 apresentaram valores consideravelmente inferiores a aqueles obtidos nos ensaios de laboratório. A viga BRS1 apresentou para sua deflexão máxima calculada no Atena um valor de $24 \%$ daquele obtido em laboratório, enquanto a BRS2 um valor de $21 \%$. Já para as vigas BRC1 e BRC2, os resultados de deflexão máxima obtidos nas simulações apresentaram-se mais próximos daqueles registrados em laboratório. A viga BRC1 apresentou a deflexão máxima de $82 \%$ daquela registrada em laboratório e a viga BRC2 um valor de $76 \%$ daquele obtido em laboratório. É possível perceber através da comparação das Figura 13, Figura 16, Figura 19 e Figura 21 com a Figura 22 que as curvas de carga-deflexão no meio do vão para as vigas BRC1 e BRC2 apresentam aparência similar com aquelas obtidas nos experimentos de RAFI et al (2007) e aquelas modeladas no Atena. Já a aparência das curvas de carga-deflexão no meio do vão para as vigas BRS1 e 
BRS2 obtidas nos experimentos pelos autores são consideravelmente diferentes daquelas resultantes dos modelos realizados no software Atena. As curvas das vigas BRS1 e BRS2 provenientes dos experimentos apresentam uma região em que a deflexão segue aumentando para carregamentos praticamente constantes, o que não é observado nos resultados da análise pelo software.

As tensões máximas registradas nas armaduras durante as análises realizadas no Atena apresentaram-se consistentes em relação aos valores obtidos nos ensaios de laboratório por RAFI et al (2007). Para a viga BRS1 foi registrado o valor de 530 MPa na armadura longitudinal de tração, valor este que representa o escoamento do aço, confirmando dessa maneira, o modo de falha da viga registrado em laboratório. Para a viga BRS2 a tensão máxima na armadura longitudinal de tração foi de $525,5 \mathrm{MPa}$, ou seja, valor bastante próximo a $530 \mathrm{MPa}$, também de acordo com o modo de falha registrado em laboratório. Com relação às vigas BRC1 e BRC2 as tensões máximas calculadas nas barras de PRFC foram de $80 \%$ da tensão de resistência na viga BRC1 e $72,7 \%$ da tensão resistente na viga BRC2. Nos ensaios de laboratório os autores registraram para essas vigas os valores entre $80 \%$ e $90 \%$ da tensão de resistência.

Em relação ao modo de falha, nas simulações realizadas no Atena, as vigas BRS1 e BRS2 apresentaram ruptura de acordo com o que foi verificado em laboratório. Entretanto, para as vigas BRC1 e BRC2 o mesmo não ocorreu. As tensões principais de compressão e as deformações principais no concreto obtidas no Atena situam-se em faixas de valores inferiores aos limites para esse material, não indicando ruptura por compressão do concreto como foi registrado nos ensaios. É possível observar ainda, que alguns valores de tensão principal e deformação superam os limites para o concreto, entretanto, isso ocorre apenas em regiões muito próximas dos pontos de aplicações das cargas e, dessa maneira, isso foi interpretado não pela ruptura da viga através do concreto, mas sim que esses valores ocorreram devido às concentrações de tensão geradas próximas aos carregamentos.

Portanto, as vigas com armadura longitudinal de tração composta por barras de aço convencionais, quando simuladas no Atena, apresentaram deflexões máximas consideravelmente inferiores ao esperado de acordo com os resultados obtidos nos ensaios de laboratório. Isso indica que o software considerou nessas vigas uma rigidez superior ao que ocorreu no cenário real. Para os modos de falha registrados por RAFI et al (2007) nas vigas BRC1 e BRC2, o software também não conseguiu apresentar resultados compatíveis com aqueles obtidos pelos autores durante os ensaios em laboratório. Para os demais parâmetros, ou seja, tensões máximas nas barras para todas as vigas, deflexão 
máxima nas vigas $B R C 1$ e BRC2, carga de fissuração em todas as vigas e modo de falha nas vigas BRS1 e BRS2, o software apresentou resultados consistentes com aqueles registrados por RAFI et al (2007) em seu trabalho.

Há de se levar em conta a dificuldade de representar o comportamento frágil do concreto através de um mecanismo matemático. Além disso, é importante ressaltar que tanto o módulo de elasticidade quanto a própria energia de fratura do concreto são parâmetros que foram estabelecidos empiricamente de acordo com equações fornecidas pela NBR 6118:2014 e pelo trabalho de HILLERBORG et al (1976). É notável a maior resistência conferida às vigas de concreto reforçadas com barras de PRFC. A carga que levou essas vigas ao colapso apresentou aproximadamente o dobro do valor daquela que rompeu as vigas reforçadas com barras de aço convencionais. Isso decorre da considerável superioridade da resistência à tração que há nas barras de polímero reforçado com fibras de carbono quando comparadas com as barras de aço. Entretanto, é importante considerar que as vigas de concreto reforçadas com barras de PRFC não apresentam ruptura dúctil, ou seja, não permitem a redistribuição de esforços e nem a indicação prévia do rompimento do elemento estrutural. Isso decorre do comportamento linear elástico até a ruptura apresentado pelo material que constitui as barras de polímero reforçado com barras de PRFC e é uma desvantagem em relação aos elementos de concreto reforçado com barras de aço. 
4.

\section{Validação das simulações realizadas no Atena}

As análises dos modelos realizadas no capítulo 3 deste trabalho foram realizadas para comparar os resultados obtidos em ensaios de laboratório por RAFI et al (2007) com os resultados calculados pelo software Atena. Neste capítulo foi realizada a comparação entre os resultados obtidos no Atena para a viga BRS2 e os resultados de alguns parâmetros calculados através de soluções analíticas. Tendo em vista que para o problema em questão é possível calcular de maneira simples a sua solução analítica, a comparação dos resultados dessa solução com aqueles obtidos através do Atena permite constatar a validade das simulações realizadas neste software.

Para o cálculo do momento fletor de fissuração $\left(M_{r}\right)$ da viga BRS2, apresentada no capítulo 3 deste trabalho, foi utilizada a equação indicada na NBR 6118:2014 em seu item 17.3.1.

$$
M_{r}=\frac{\alpha \cdot f_{c t} \cdot I_{c}}{y_{t}}
$$

em que:

$\alpha=1,5$ para seções retangulares. É o fator que correlaciona aproximadamente a resistência à tração na flexão com a resistência à tração direta;

$y_{t}$ é a distância do centro de gravidade da seção à fibra mais tracionada;

$I_{C}$ é o momento de inércia da seção bruta de concreto;

$f_{c t}$ é a resistência à tração direta do concreto. Para determinar o momento de fissuração deve ser utilizado o valor de $f_{c t k, \text { inf }}$ no estado limite de formação de fissuras.

Dessa maneira:

$$
f_{c t}=0,7 \times 0,3 \times\left(f_{c k}\right)^{2 / 3}
$$

Para a viga BRS2, o concreto apresentou resistência à compressão $\left(f_{c k}\right)$ igual a $45 \mathrm{MPa}$ :

$$
f_{c t}=0,7 \times 0,3 \times(45)^{2 / 3}=2,6568 M P a=2656,8 \mathrm{kN} / \mathrm{m}^{2}
$$




$$
\begin{gathered}
I_{c}=\frac{0,12 \times 0,2^{3}}{12}=8 \times 10^{-5} \mathrm{~m}^{4} \\
y_{t}=0,1 \mathrm{~m} \\
M_{r}=\frac{1,5 \times 2656,8 \times 8 \times 10^{-5}}{0,1}=3,19 \mathrm{kN} . \mathrm{m}
\end{gathered}
$$

A partir do momento fletor de fissuração, é possível calcular o carregamento que induz o surgimento da primeira fissura na viga. A Figura 23 apresenta o diagrama de momentos fletores para a viga em questão.
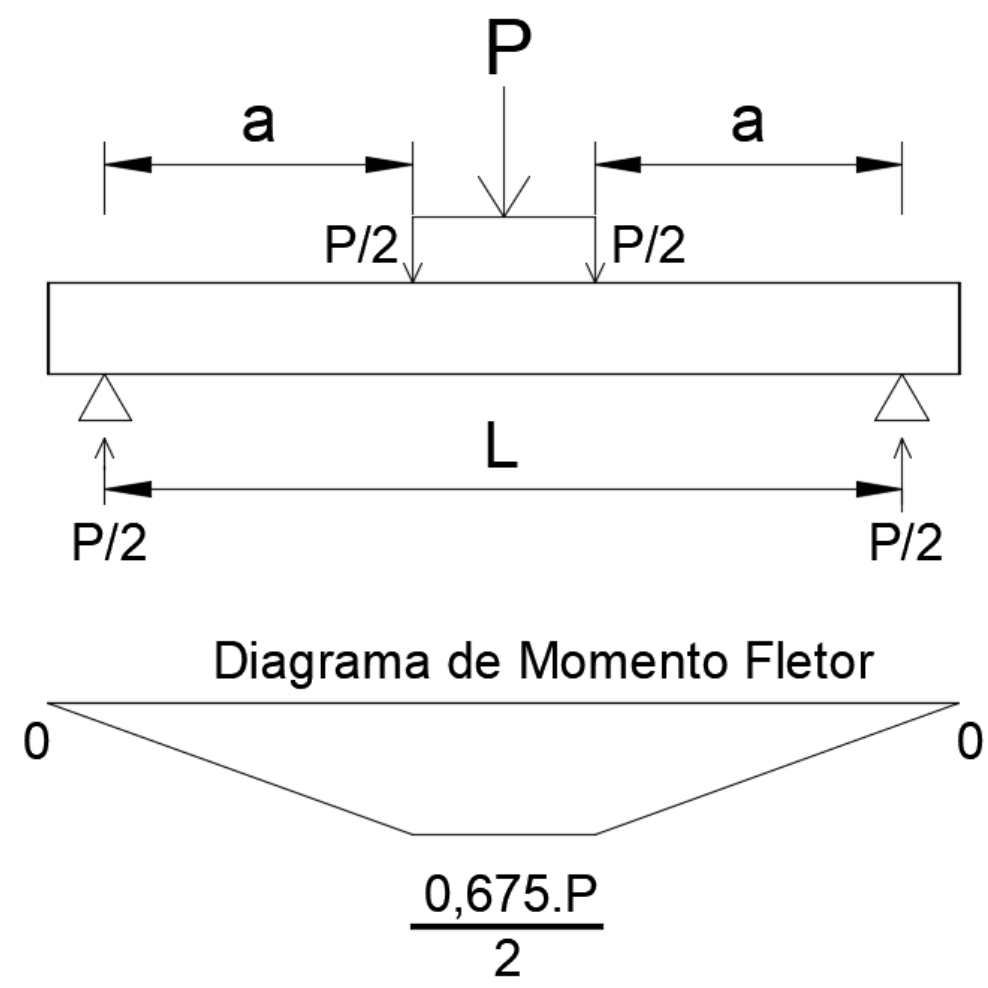

Figura 23 - Diagrama de momento fletor que atua na viga analisada.

Portanto, o carregamento que insere nessa viga o momento fletor de fissuração pode ser calculado.

$$
\frac{0,675 \cdot P}{2}=3,19
$$




$$
P=9,45 k N
$$

A deflexão máxima $\left(f_{\text {máx }}\right)$ da viga em regime elástico, ou seja, anteriormente ao surgimento da primeira fissura, dada pela solução analítica para a viga apresentada, ocorre no meio do vão e é dada de acordo com:

$$
f_{\text {máx }}=\frac{\frac{P}{2} \cdot a \cdot\left(3 L^{2}-4 a^{2}\right)}{24 E I}
$$

Para o cálculo da deflexão máxima no meio do vão da viga foi considerado o carregamento $P=9,0 \mathrm{kN}$. Esse carregamento foi adotado na análise por apresentar-se próximo, mas inferior ao valor da carga que leva a viga à fissuração na solução analítica, ou seja, possibilitando sua utilização no cálculo da deflexão máxima da viga em regime elástico. Para o cálculo do módulo de elasticidade $(E)$ foi utilizada a equação indicada pela NBR 6118:2014 com $\alpha=1$ (considerando granito para o agregado graúdo na composição do concreto).

$$
\begin{gathered}
E=E_{c s}=\alpha \cdot 5600 \cdot \sqrt{f_{c k}} \\
E=E_{c s}=1 \times 5600 \times \sqrt{45}=37565,9 \mathrm{MPa}=37,5659 \mathrm{GPa} \\
f_{\text {máx }}=\frac{\frac{9,0}{2} \cdot 0,675 .\left(3 \times 1,75^{2}-4 \times 0,675^{2}\right)}{24 \times 37,5659 \times 10^{6} \times 8 \times 10^{-5}}=0,00031 \mathrm{~m}=0,31 \mathrm{~mm}
\end{gathered}
$$

A partir dos parâmetros de carga de fissuração e deflexão máxima em regime elástico calculados através da solução analítica, foi possível comparar os resultados gerados pelo software Atena para a viga em questão. Com o objetivo de se obter maior precisão na carga de fissuração, foram utilizados incrementos de carregamento de 1,0 kN no Atena. A Figura 24 apresenta a viga BRS2 e o incremento de carga (na unidade de MN) utilizado para a comparação com os resultados da solução analítica. 


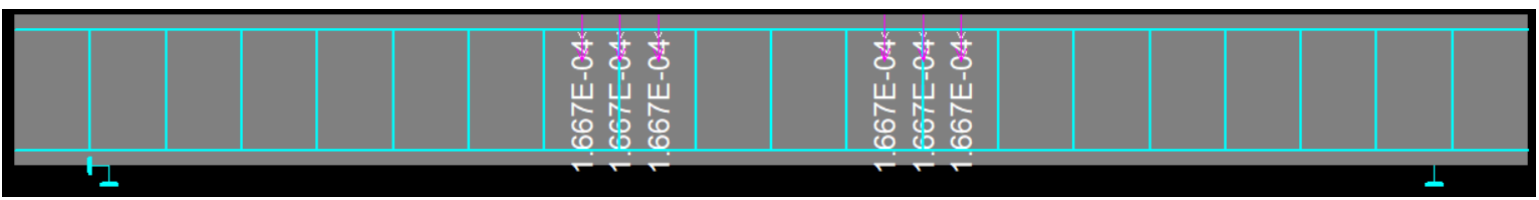

Figura 24 - Viga BRS2 e incremento de carga utilizado para a comparação com os resultados da solução analítica.

A carga de fissuração calculada através da simulação realizada no Atena foi de 11 kN. Essa carga, as reações verticais de apoio correspondentes e as fissuras estão ilustradas na Figura 25, ressaltando que as forças são apresentadas na unidade de MN.

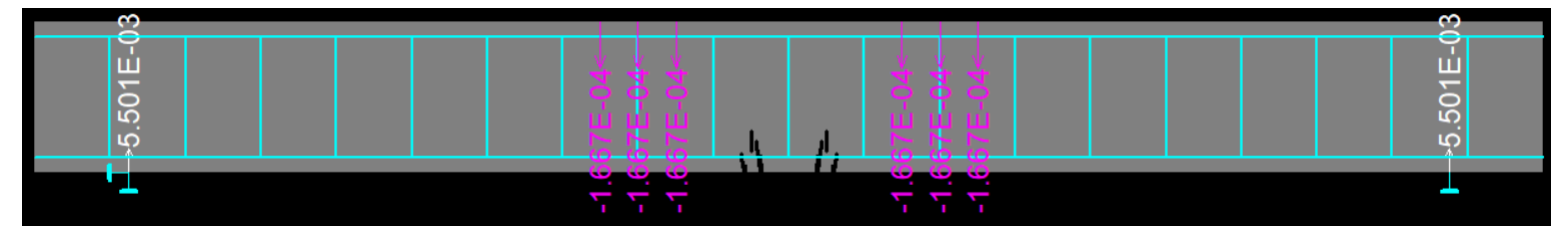

Figura 25 - Carga de fissuração, reações verticais de apoio correspondentes e fissuras para o carregamento em questão.

O resultado referente à deflexão máxima na viga para o carregamento de 9,0 kN, foi de aproximadamente $0,30 \mathrm{~mm}$ e o gráfico de força - deslocamento vertical no meio do vão está apresentado na Figura 26. 0 ponto destacado nessa figura representa o $9^{\circ}$ incremento de carga, ou seja, corresponde ao carregamento total de 9,0 kN inserido na viga. 


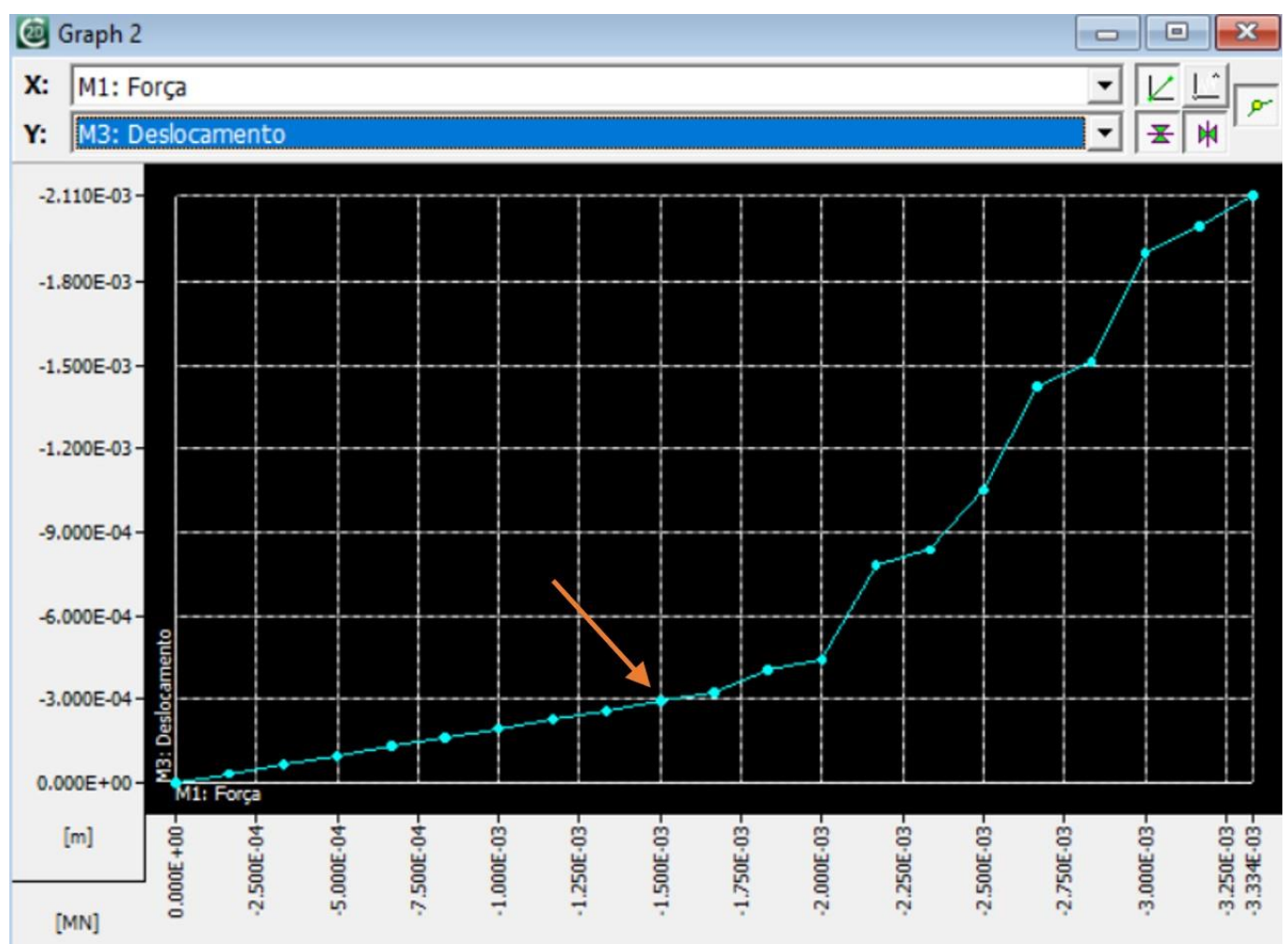

Figura 26 - Deflexão máxima na viga para o carregamento de 9,0 kN.

A partir do cálculo realizado no Atena, foi possível estabelecer a comparação dos resultados obtidos através da solução analítica e aqueles gerados pelo software em questão. Esses resultados estão apresentados na Tabela 5.

Tabela 5 - Resultados da carga de fissuração e deflexão máxima na viga.

\begin{tabular}{c|c|c}
\hline Solução & Carga de fissuração $(\mathrm{kN})$ & Deflexão Máxima $(\mathrm{mm})$ \\
\hline Analítica & 9,45 & 0,30 \\
Atena & 11,0 & 0,31 \\
\hline
\end{tabular}

A partir da Tabela 5 é possível verificar que a diferença entre a carga de fissuração calculada pela solução analítica e aquela obtida através da simulação realizada no Atena apresentam diferença de aproximadamente $14 \%$ entre seus valores. É interessante notar que para a carga de fissuração, os resultados da solução analítica e do software estão mais próximos entre si do que o valor de $7,5 \mathrm{kN}$, encontrado por RAFI et al (2007) em laboratório, como está apresentado no capítulo 3 deste trabalho. É importante ressaltar 
a dificuldade de se representar o comportamento frágil real do concreto através de modelos matemáticos, sejam estes modelos baseados em soluções analíticas simples ou mesmo provenientes de complexos processos de iteração que ocorrem nos programas de elementos finitos com análise não linear.

Em relação à deflexão máxima calculada antes de ocorrer a fissuração na viga, ou seja, com esse elemento atuando em regime elástico, os resultados provenientes da solução analítica e do software apresentaram valor praticamente igual. A diferença entre os valores foi de apenas 3,2 \% aproximadamente. Isso demonstra a consistência dos resultados gerados pelo software utilizado. 


\section{5. \\ Dimensionamento à flexão}

Neste capítulo foram dimensionadas duas vigas de concreto submetidas à flexão, sendo a primeira reforçada com barras de aço e a segunda reforçada com barras de PRFC. Foi considerada uma viga com seção transversal de $15 \mathrm{~cm} \times 30 \mathrm{~cm}$, altura útil (d) de 26,5 $\mathrm{cm}$, concreto com resistência à compressão de $30 \mathrm{MPa}$ e elemento sob condições internas de exposição ambiental. Foi considerado um momento fletor referente ao dobro do valor do momento fletor mínimo, calculado de acordo com a NBR 6118:2014.

$$
M_{d, \min }=0,8 \cdot W_{0} \cdot f_{c t k, s u p}
$$

em que:

$W_{0}$ é o módulo de resistência da seção transversal bruta de concreto, relativo à fibra mais tracionada;

$f_{c t k, s u p}$ é a resistência característica superior do concreto à tração.

Assim:

$$
M_{d, \min }=\frac{0,8 \times\left(\frac{0,2 \times 0,4^{3}}{12}\right) \times 1,3 \times 0,3 \times 30^{2 / 3} \times 1000}{0,2}=16,1 \mathrm{kN} . \mathrm{m}
$$

O momento fletor utilizado no dimensionamento foi então de $M_{d}=2 \times 16,1=$ 32,2 kN.m.

5.1.

Viga reforçada com barras de aço

Inicialmente foi realizado o dimensionamento da armadura utilizando barras de aço CA-50. Os cálculos seguem de acordo com:

$$
k_{m d}=\frac{32,2}{0,15 \times 0,265^{2} \times \frac{30000}{1,4}}=0,14265
$$




$$
\begin{gathered}
k_{x}=\frac{1-\sqrt{1-\frac{2 \times 0,14265}{0,85}}}{0,8}=0,23116 \\
k_{z}=1-0,4 \times 0,23116=0,90754 \\
A_{s}=\frac{32,2}{0,90754 \times 0,265 \times \frac{50}{1,15}}=3,08 \mathrm{~cm}^{2}
\end{gathered}
$$

\section{2.}

\section{Viga reforçada com barras de PRFC}

Para dimensionar a armadura composta por barras de PRFC foi utilizado o método de dimensionamento para vigas de concreto submetidas à flexão reforçadas com barras de PRF apresentado na norma americana ACl 440 - 2015 (Guide for the Design and Construction of Structural Concrete Reinforced with Fiber-Reinforced Polymer Bars). Inicialmente são definidos os seguintes parâmetros:

$\rho_{f}$ - Taxa de reforço formado por barras de PRF.

$\rho_{f b}-$ Taxa balanceada de reforço formado pelas barras de PRF.

$A_{f}$-Área referente ao reforço formado pelas barras de PRF.

$E_{f}$ - Módulo de elasticidade de projeto referente às barras de PRF.

$f_{c}^{\prime}$ - Tensão característica de compressão do concreto.

$f_{f u}$ - Resistência à tração de projeto das barras de PRF. É a resistência característica multiplicada pelo fator de redução referente ao ambiente em que o elemento está inserido.

$\varepsilon_{c u}$ - Deformação última do concreto.

$f_{f}$ - Tensão de tração nas barras de reforço.

$M_{n}$ - Capacidade nominal de momento fletor.

$C_{E}$ - Fator ambiental de redução para as diversas fibras utilizadas e diferentes condições de exposição ambientais.

$a$-Altura do bloco retangular de tensões de compressão no concreto. 
$\beta_{1}$ - Taxa da profundidade do bloco retangular de tensões no concreto em relação à profundidade da linha neutra.

A norma americana $\mathrm{ACl} 440-2015$ considera as seguintes premissas para o projeto de elementos de concreto submetidos à flexão e reforçados com barras de PRF:

a) A deformação no concreto e no reforço de PRF é proporcional à distância da linha neutra. A seção permanece plana após o carregamento.

b) A máxima deformação no concreto é considerada igual a 0,003, diferenciando-se da norma brasileira NBR 6118:2014, a qual considera 0,0035 para a deformação máxima de compressão no concreto em flexão.

c) A resistência à tração do concreto é desprezada.

d) O comportamento da tensão de tração nas barras de PRF é linear elástico até o rompimento.

e) É considerada aderência perfeita entre as barras de PRF e o concreto.

A norma americana define fatores de redução da tensão nominal resistente de tração para diferentes tipos de fibras utilizadas no reforço de barras poliméricas, variando de acordo com a exposição ambiental a qual a estrutura está submetida. Esses fatores de redução estão apresentados na Tabela 6.

\section{Tabela 6 - Fatores de redução para as diferentes fibras de acordo com a exposição ambiental (ACl 440-2015).}

\begin{tabular}{c|c|c}
\hline $\begin{array}{c}\text { Condição de } \\
\text { exposição ambiental }\end{array}$ & Tipo de fibra & $\begin{array}{c}\text { Fator de redução } \\
\text { ambiental }\left(\mathrm{C}_{\mathrm{E}}\right)\end{array}$ \\
\hline $\begin{array}{c}\text { Concreto não } \\
\text { exposto ao tempo }\end{array}$ & Carbono & 1,0 \\
& Vidro & 0,8 \\
Aramida & 0,9 \\
Concreto exposto ao & Carbono & 0,9 \\
tempo & Vidro & 0,7 \\
& Aramida & 0,8 \\
\hline
\end{tabular}

Segundo a $\mathrm{ACl} 440-2015$, a capacidade de flexão de um elemento de concreto reforçado com barras de PRF é dependente do processo que leva o elemento à ruptura, seja por compressão do concreto ou pelo rompimento do reforço. O processo pelo qual a viga atinge o estado limite de ruptura pode ser determinado pela comparação entre a 
taxa de armadura composta por barras de PRF e a taxa balanceada de armadura, a qual representa a taxa de reforço em que o concreto rompe por compressão simultaneamente à ruptura do reforço. Como as barras de PRF não plastificam, a taxa balanceada desse reforço é considerada utilizando sua resistência à tração de projeto.

Taxa de armadura:

$$
\rho_{f}=\frac{A_{f}}{b d}
$$

Taxa balanceada da armadura:

$$
\rho_{f b}=0,85 \beta_{1} \frac{f_{c}^{\prime}}{f_{f u}} \frac{E_{f} \varepsilon_{c u}}{E_{f} \varepsilon_{c u}+f_{f u}}
$$

A Tabela 7 apresenta valores típicos para a taxa balanceada de reforço para uma seção retangular de concreto com $f_{c}^{\prime}=34,5 \mathrm{MPa}$.

Tabela 7 - Valores típicos para a taxa balanceada de reforço para uma seção retangular de

\begin{tabular}{|c|c|c|c|}
\hline Tipo de barra & $\begin{array}{l}\text { Tensão de escoamento }\left(f_{\mathrm{y}}\right) \\
\text { ou tensão resistente }\left(\mathrm{f}_{\mathrm{fu}}\right) \\
\text { (MPa) }\end{array}$ & $\begin{array}{c}\text { Módulo de } \\
\text { elasticidade (GPa) }\end{array}$ & $\rho_{b}$ ou $\rho_{f b}$ \\
\hline Aço & 414 & 200 & 0.035 \\
\hline PRF Vidro & 552 & 41.4 & 0.0078 \\
\hline PRF Aramida & 1172 & 82.7 & 0.0035 \\
\hline PRF Carbono & 2070 & 152 & 0.002 \\
\hline
\end{tabular}
concreto $\operatorname{com} f_{c}^{\prime}=34,5 \mathrm{MPa}(\mathrm{ACl}$ 440-2015).

Se a taxa de armadura for inferior à taxa balanceada, o estado limite de ruptura é conduzido pelo rompimento por tração do reforço formado pelas barras de PRF. Caso a taxa de armadura seja superior à taxa balanceada, o estado limite de ruptura é governado pela compressão do concreto. Para o caso em que o estado limite de ruptura é governado pela compressão do concreto $\left(\rho_{f}>\rho_{f b}\right)$, a distribuição das tensões no concreto pode ser aproximada através do bloco retangular de tensões. Portanto, com base no equilíbrio das forças e compatibilidade de deformações, a resistência nominal à flexão (momento fletor nominal resistente) é dada por: 


$$
\begin{gathered}
M_{n}=A_{f} f_{f}\left(d-\frac{a}{2}\right) \\
a=\frac{A_{f} f_{f}}{0,85 f_{c}^{\prime} b} \\
f_{f}=E_{f} \varepsilon_{c u} \frac{\beta_{1} d-a}{a} \\
f_{f}=\left(\sqrt{\left.\frac{\left(E_{f} \varepsilon_{c u}\right)^{2}}{4}+\frac{0,85 \beta_{1} f_{c}^{\prime}}{\rho_{f}} E_{f} \varepsilon_{c u}-0,5 E_{f} \varepsilon_{c u}\right) \leq f_{f u}}\right.
\end{gathered}
$$

Dessa maneira, a resistência nominal à flexão em uma seção transversal pode ser expressa a partir da taxa de armadura de acordo com:

$$
M_{n}=\rho_{f} f_{f}\left(1-0,59 \frac{\rho_{f} f_{f}}{f_{c}^{\prime}}\right) b d^{2}
$$

Para o caso em que o estado limite de ruptura é governado pelo rompimento do reforço $\left(\rho_{f}<\rho_{f b}\right)$, a resistência nominal à flexão da seção pode ser dada por:

$$
M_{n}=A_{f} f_{f u}\left(d-\frac{\beta_{1} c}{2}\right)
$$

Apesar da tensão no reforço ser conhecida, há duas incógnitas nesse caso. A deformação de encurtamento do concreto $\left(\varepsilon_{c}\right)$ e a profundidade da linha neutra $(c)$. A análise envolvendo essas duas incógnitas se dá através de uma solução complexa e o bloco retangular de tensões equivalente não pode ser utilizado, pois a deformação máxima no concreto pode não ser atingida. Para uma determinada seção, o produto de $\beta_{1} c$ varia de acordo com as propriedades dos materiais e com a taxa de reforço formado pelas barras de PRF. Para uma seção transversal cuja ruptura é governada pela ruptura do reforço de barras de PRF, o máximo valor desse produto é $\beta_{1} c_{b}$ e é alcançado quando a máxima deformação de encurtamento no concreto (0,003 na $\mathrm{ACl} 440$-2015) é alcançada. Portanto, uma simplificação conservativa para o cálculo da resistência nominal à flexão do elemento pode ser obtida de acordo com: 


$$
\begin{gathered}
M_{n}=A_{f} f_{f u}\left(d-\frac{\beta_{1} c_{b}}{2}\right) \\
c_{b}=\left(\frac{\varepsilon_{c u}}{\varepsilon_{c u}+\varepsilon_{f u}}\right) d
\end{gathered}
$$

Considerando que as barras de PRF não apresentam comportamento dúctil, uma redução conservativa da resistência nominal à flexão deve ser adotada por meio de um fator de redução $(\phi)$ para manter uma reserva de resistência no elemento estrutural. Dessa maneira, para garantir a segurança da viga sob flexão:

$$
\phi M_{n} \geq M_{u}
$$

É interessante notar que apesar da ruptura controlada pela compressão do concreto poder ser prevista por meio dos cálculos, o elemento construído talvez não atinja a ruptura de acordo com esse processo. Por exemplo, se o concreto apresentar resistência à compressão superior a aquela especificada, a capacidade da seção pode acabar sendo governada pela ruptura do reforço de barras de PRF. Por esta razão, uma seção de concreto reforçada com barras de PRF tem o processo de ruptura por flexão governado pela compressão do concreto quando $\rho_{f}>1,4 \rho_{f b}$ e governado pela ruptura do reforço tracionado quando $\rho_{f}<\rho_{f b}$. Para uma seção em que $\rho_{f b}<\rho_{f}<1,4 \rho_{f b}$, teoricamente o processo de ruptura é controlado pela compressão do concreto, porém, uma redução no valor de $\phi$ deve ser utilizada. Portanto, o fator de redução da resistência à flexão pode ser calculado de acordo com:

$$
\Phi=\left\{\begin{array}{c}
0,55 \text { para } \rho_{f}<\rho_{f b} \\
0,3+0,25 \frac{\rho_{f}}{\rho_{f b}} \text { para } \rho_{f b}<\rho_{f}<1,4 \rho_{f b} \\
0,65 \text { para } \rho_{f}>1,4 \rho_{f b}
\end{array}\right.
$$

Quando o processo de ruptura é governado pelo rompimento das barras tracionadas, ou seja, para vigas com $\rho_{f}<\rho_{f b}$ é prevista uma taxa mínima de armadura, para que seja evitada a falha por meio das fissuras no concreto, $\phi M_{n} \geq M_{c r}$, sendo $M_{c r}$, 
o momento fletor de fissuração. A armadura mínima, em unidades do sistema internacional (SI), é dada por:

$$
A_{f, \min }=\frac{0,41 \sqrt{f_{c}^{\prime}}}{f_{f u}} b d \geq \frac{2,3}{f_{f u}} b d
$$

Para o caso em que o processo de ruptura da viga sob flexão é governado pela compressão do concreto, $\rho_{f}>\rho_{f b}$, a armadura mínima já está automaticamente considerada.

Uma vez que o método de dimensionamento utilizado pela ACl 440-2015 tenha sido apresentado, o cálculo da armadura formada por barras de PRFC pode ser realizado. Foram consideradas as características apresentadas na Tabela 7 para os parâmetros de resistência mecânica das barras, sendo $f_{f u}^{*}=2070 \mathrm{MPa}$ e $E_{f}=152 \mathrm{GPa}$.

$$
C_{E}=1,0
$$

$$
f_{f u}=C_{E} f_{f u}^{*}=1 \times 2070=2070 M P a
$$

\subsection{1.}

\section{Ruptura governada pela compressão do concreto}

Partindo inicialmente de uma taxa de $\rho_{f}=1,5 \rho_{f b}$, os cálculos seguem de acordo com:

$$
\begin{gathered}
\rho_{f b}=0,85 \times 0,85 \times \frac{30}{2070} \frac{152000 \times 0,003}{152000 \times 0,003+2070}=0,00189 \\
\rho_{f}=1,5 \rho_{f b}=1,5 \times 0,00189=0,002835
\end{gathered}
$$

Tendo em vista que $\rho_{f}>1,4 \rho_{f b}$, a seção tem sua ruptura governada pela compressão do concreto, sendo assim, $\phi=0,65$. Dessa maneira, o cálculo da tensão no reforço para a taxa de armadura considerada pode ser realizado. 


$$
\begin{gathered}
E_{f} \varepsilon_{c u}=152000 \times 0,003=456 \mathrm{MPa} \\
f_{f}=\left(\sqrt{\frac{(456)^{2}}{4}+\frac{0,85 \times 0,85 \times 30}{0,002835} \times 456}-0,5 \times 456\right) \leq 2070 \\
f_{f}=\sqrt{51984+3486349,2}-228=1653 \mathrm{MPa}
\end{gathered}
$$

Após o cálculo da tensão no reforço, pode-se calcular a capacidade de momento resistente que essa seção transversal apresenta.

$$
\begin{gathered}
\rho_{f} \cdot f_{f}=0,002835 \times 1653000=4686,255 \mathrm{kN} / \mathrm{m}^{2} \\
M_{n}=4686,255 \times\left(1-0,59 \times \frac{4686,255}{30000}\right) \times 0,15 \times 0,265^{2} \\
M_{n}=44,8 \mathrm{kN} . \mathrm{m}
\end{gathered}
$$

Aplicando o fator de redução de 0,65.

$$
\begin{gathered}
\phi M_{n} \geq M_{u} \\
0,65 \times 44,8=29,1 \mathrm{kN} . \mathrm{m}
\end{gathered}
$$

$$
29,1 \text { kN.m }<32,2 \text { kN.m } \rightarrow \quad N \text { ÂO OK }
$$

A aplicação do fator de redução indica que pelo método de dimensionamento apresentado pela $\mathrm{ACl}$ 440-2015 a seção considerada não é capaz de suportar o momento fletor de projeto. Dessa forma, pode-se elevar a taxa de armadura utilizada e verificar novamente os cálculos. Considerando $\rho_{f}=2,0 \rho_{f b}$.

$$
\rho_{f}=2,0 \rho_{f b}=2,0 \times 0,00189=0,00378
$$




$$
\begin{gathered}
f_{f}=\left(\sqrt{\frac{(456)^{2}}{4}+\frac{0,85 \times 0,85 \times 30}{0,00378} \times 456}-0,5 \times 456\right) \leq 2070 \\
f_{f}=\sqrt{51984+2905291}-228=1405 \mathrm{MPa} \\
f_{f}=\sqrt{51984+2905291}-228=1405 \mathrm{MPa} \\
\rho_{f} \cdot f_{f}=0,00378 \times 1405000=5310,9 \mathrm{kN} / \mathrm{m}^{2} \\
M_{n}=5310,9 \times\left(1-0,59 \times \frac{5310,9}{30000}\right) \times 0,15 \times 0,265^{2} \\
32,6 \mathrm{kN} . \mathrm{m}>32,2 \mathrm{kN} . \mathrm{m} \rightarrow O \mathrm{~K} \\
0,65 \times 50,1=32,6 \mathrm{kN} . \mathrm{m}
\end{gathered}
$$

Pode-se perceber que ao utilizar barras de polímero reforçado com fibras de carbono e uma taxa de armadura $\rho_{f}=2,0 \rho_{f b}$ é possível dimensionar a seção transversal em questão para suportar um momento fletor de $32,2 \mathrm{kN} . \mathrm{m}$ com o estado limite de ruptura sendo governado pela compressão do concreto de acordo com o método apresentado na $\mathrm{ACl}$ 440-2015. É possível, portanto, calcular a armadura necessária na seção.

$$
\begin{gathered}
0,00378=\frac{A_{f}}{15 \times 26,5} \\
A_{f}=1,5 \mathrm{~cm}^{2}
\end{gathered}
$$




\subsection{2.}

\section{Ruptura governada pelo rompimento do reforço}

Para o caso de o processo de ruptura da seção ser governado pelo rompimento do reforço, tem-se que $\rho_{f}<\rho_{f b}$. Considerando então que $\rho_{f}=0,90 \rho_{f b}$, pode-se calcular a taxa de armadura utilizada.

$$
\begin{gathered}
c_{b}=\left(\frac{0,003}{0,003+\frac{2070}{152000}}\right) \times 0,265=0,0478 \mathrm{~m} \\
M_{n}=A_{f} \times 2070 \times 10^{3} \times\left(0,265-\frac{0,85 \times 0,0478}{2}\right) \\
M_{n}=506497,95 A_{f} \\
\phi M_{n} \geq M_{u}
\end{gathered}
$$

Para $\rho_{f}<\rho_{f b}, \phi=0,55$.

$$
\begin{gathered}
0,55 M_{n} \geq 32,2 \mathrm{kN} \cdot \mathrm{m} \\
M_{n} \geq 58,5 \mathrm{kN} \cdot \mathrm{m} \\
58,5=506497,95 A_{f} \\
A_{f}=1,15 \mathrm{~cm}^{2}
\end{gathered}
$$

Para o caso em que a ruptura é governada pelo rompimento do reforço, deve-se verificar a armadura mínima na seção.

$$
\begin{gathered}
A_{f, \text { min }}=\frac{0,41 \sqrt{30}}{2070} \times 15 \times 26,5=0,43 \mathrm{~cm}^{2} \\
A_{f, \text { min }} \geq \frac{2,3}{f_{f u}} b d
\end{gathered}
$$




$$
\begin{gathered}
A_{f, \text { mín }}=\frac{0,41 \sqrt{f_{c}^{\prime}}}{f_{f u}} b d \geq \frac{2,3}{2070} \times 15 \times 26,5=0,44 \mathrm{~cm}^{2} \\
A_{f, \text { mín }}=0,44 \mathrm{~cm}^{2}
\end{gathered}
$$

A armadura dimensionada de $1,15 \mathrm{~cm}^{2}$ é, portanto, superior à armadura mínima necessária na seção.

\section{3.}

\section{Carregamento último para a viga reforçada com barras de aço}

Para exemplificar a redistribuição de esforços que pode ocorrer nas estruturas de concreto hiperestáticas reforçadas com barras de aço, foi efetuado o cálculo da capacidade de rotação plástica para a seção transversal de uma viga de concreto armado de forma a possibilitar que a estrutura atinja o rompimento com um carregamento superior àquele em que foi dimensionada. Para o cálculo da capacidade de rotação plástica é necessário conhecer previamente as resistências dos materiais, as seções transversais e as armaduras. No presente trabalho a estimativa da capacidade de rotação plástica foi obtida através do diagrama simplificado de momento-curvatura apresentado na Figura 27, adaptado de BUCHAIM (2001). É importante ressaltar que esse é um diagrama simplificado, no qual os trechos são lineares. O diagrama exato de momentocurvatura de uma seção de concreto armado se dá através das leis constitutivas do concreto e do aço. A lei constitutiva do concreto não é linear na realidade e, além disso, após o aço atingir seu escoamento, o ganho de resistência que ainda ocorre nesse material também não é linear. Para traçar o diagrama exato é necessário deformar a seção transversal de maneira a obter os momentos fletores gerados em cada uma das deformações para uma determinada força normal (podendo inclusive ser 0 ). As forças que equilibram a seção em cada uma das deformações são provenientes da relação entre tensão e deformação na região do diagrama em que se está analisando. Por isso a necessidade de se utilizar as leis constitutivas reais para traçar o diagrama de momentocurvatura real de uma seção transversal de concreto armado. 


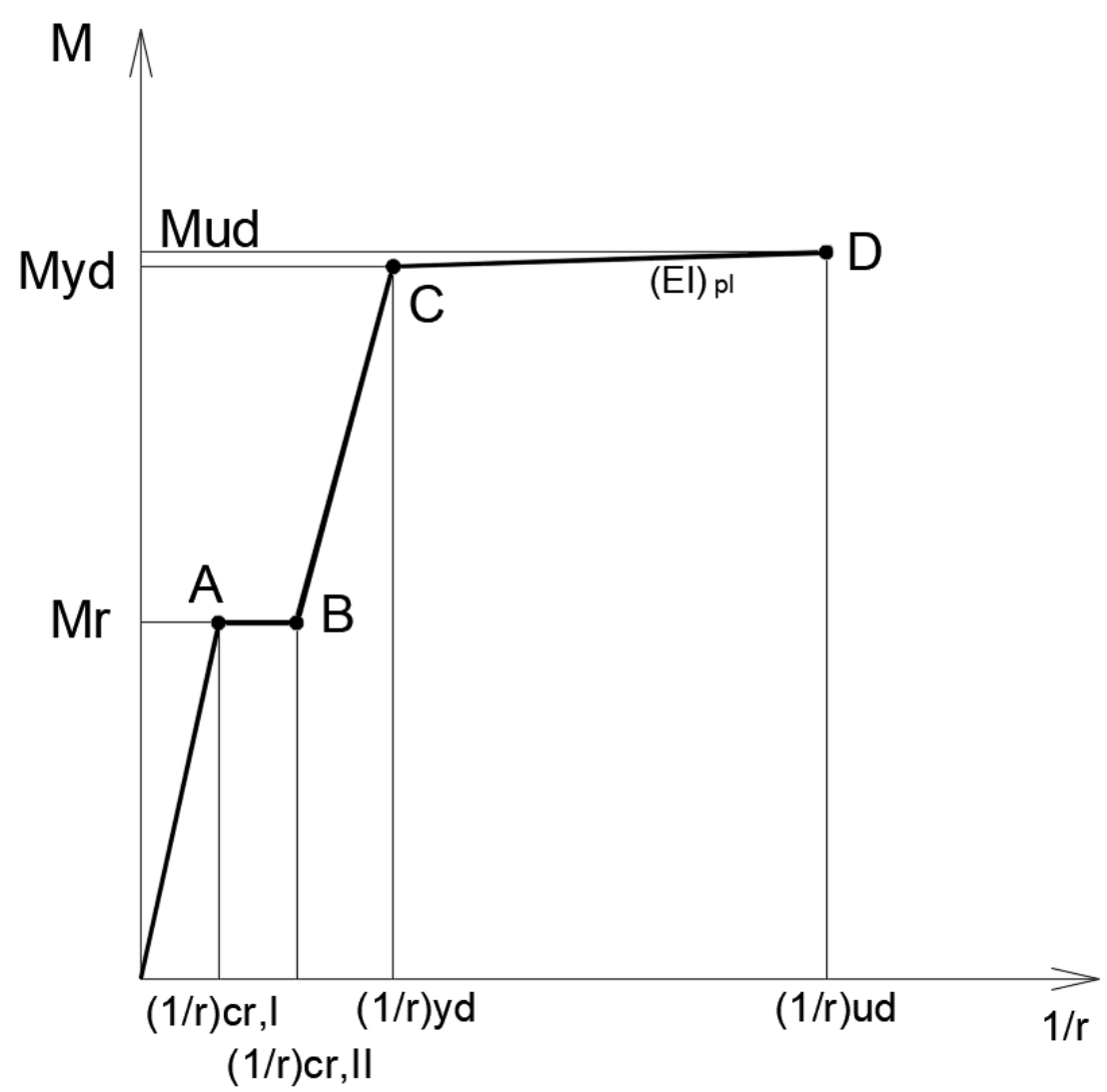

Figura 27 - Diagrama simplificado de momento-curvatura utilizado para estimar a capacidade de rotação plástica da seção transversal analisada.

Sendo:

$M_{r}$ o momento de fissuração, calculado de acordo com a NBR 6118:2014;

$M_{y d}$ o momento fletor resistente da seção no ELU;

$M_{u d}$ o momento fletor último da seção, considerando o acréscimo da resistência do aço após atingir o escoamento.

$\left(\frac{1}{r}\right)_{c r, I}$ a curvatura da seção transversal no instante em que a peça atinge o momento fletor de fissuração imediatamente antes da fissuração ocorrer;

$\left(\frac{1}{r}\right)_{c r, I I}$ a curvatura da seção transversal no instante em que a peça atinge o momento fletor de fissuração imediatamente após a fissuração ocorrer;

$\left(\frac{1}{r}\right)_{y d}$ a curvatura da seção no instante em que a armadura atinge o escoamento;

$\left(\frac{1}{r}\right)_{u d}$ a curvatura da seção no instante em que a seção atinge o momento fletor último.

A redistribuição dos esforços foi realizada para uma viga contínua com armadura previamente conhecida. Essa viga foi considerada com concreto C-30, aço CA-50 e mesma 
armadura em todas as seções, diferenciando apenas a face onde essa armadura é disposta (face inferior ou face superior). A viga e sua seção transversal estão apresentadas na Figura 28.

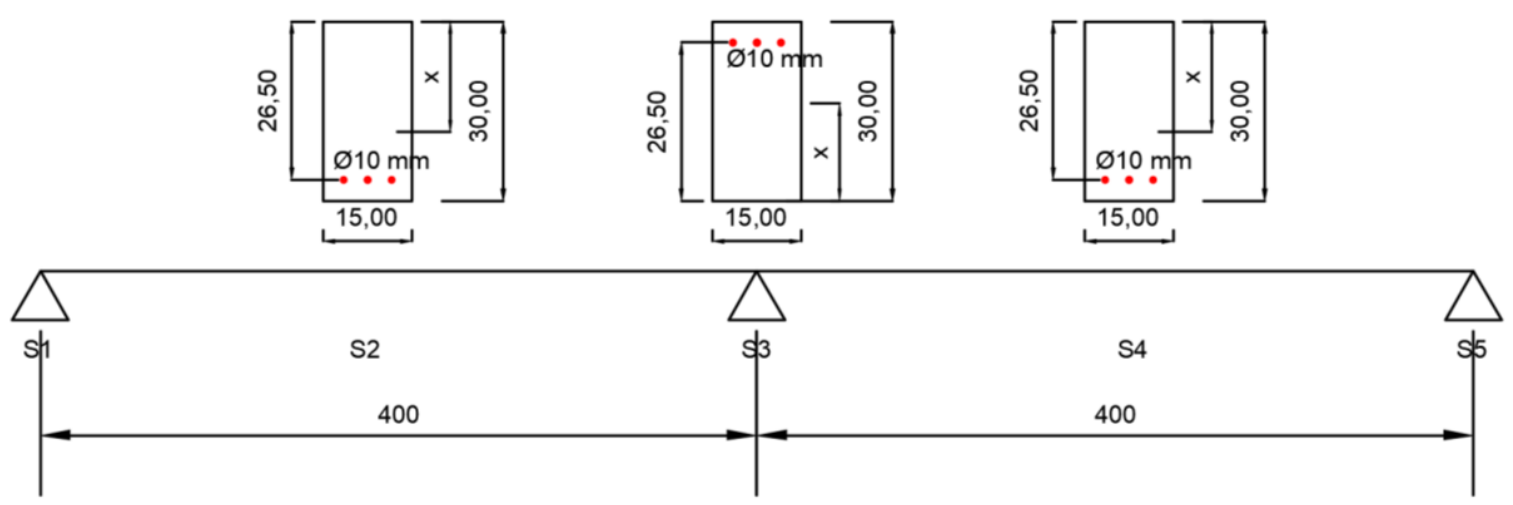

Figura 28 - Viga contínua e armadura previamente estabelecida.

Inicialmente foi calculado o carregamento uniformemente distribuído que aplicado ao longo de todo o comprimento da viga faz com que o momento fletor resistente seja atingido em alguma seção transversal. Considerando um carregamento uniformemente distribuído em toda a extensão dessa viga, o maior momento fletor ocorre na seção S3, ou seja, no apoio central da viga, tracionando a face superior desse elemento. A partir do conhecimento da armadura é possível calcular o momento fletor máximo que essa viga pode suportar no estado limite último para qualquer uma de suas seções transversais, visto que em todas elas a armadura é a mesma. O cálculo do máximo momento fletor resistente se dá de maneira a encontrar o binário de forças resistentes (tração na armadura e compressão no concreto) que pode ocorrer na seção. Para isso, calcula-se a força $\left(F_{S}\right)$ de tração na armadura a partir da multiplicação da área de aço $\left(A_{S}\right)$ total e a tensão de dimensionamento do aço $\left(f_{y d}\right)$. Para que surja na seção um binário resistente, a força $\left(F_{c}\right)$ de compressão no concreto deve ser igual à força de tração no aço e dessa forma, é possível calcular a profundidade $(x)$ da linha neutra que origina esse valor de força de compressão no concreto. O procedimento se dá de acordo com:

$$
\begin{gathered}
F_{s}=A_{S} \cdot f_{y d} \\
F_{S}=\left(3 \times \pi \times 0,5^{2}\right) \times \frac{50}{1,15}=102,4 k N
\end{gathered}
$$


A força de compressão no concreto é então igualada à força de tração no aço. Essa força de compressão é igual a área de concreto comprimida multiplicada pela tensão de resistência à compressão $\left(f_{c d}\right)$ de dimensionamento do concreto. Considerando a lei rígido plástica que utiliza o bloco retangular de tensões para o concreto, tem-se que a profundidade da linha neutra $x$, pode ser dada por $y$, sendo $y=0,8 x$. Dessa forma:

$$
\begin{gathered}
F_{c}=(b \cdot 0,8 x) \cdot 0,85 \cdot f_{c d} \\
102,4=(0,15 \times 0,8 x) \times 0,85 \times \frac{30000}{1,4} \\
102,4=2185,7 x \\
x=0,0468 \mathrm{~m} \rightarrow 4,68 \mathrm{~cm}
\end{gathered}
$$

A partir do valor da profundidade da linha neutra é possível obter o braço de alavanca $z$, que separa a força de tração na armadura e a força de compressão no concreto.

$$
z=26,5-\frac{4,68}{2}=24,16 \mathrm{~cm}
$$

O momento fletor resistente $\left(M_{\text {res }}\right)$ é então o produto da força de compressão ou da força de tração, pois $F_{c}=F_{S}$, pelo braço de alavanca $z$.

$$
M_{\text {res }}=102,4 \times 0,2416=24,7 \mathrm{kN} . \mathrm{m}
$$

Dessa maneira, para a viga da Figura 28 o momento resistente de dimensionamento é igual a 24,7 kN.m e para este momento surgir no apoio central a configuração do diagrama de momentos fletores é dada de acordo com a Figura 29. 


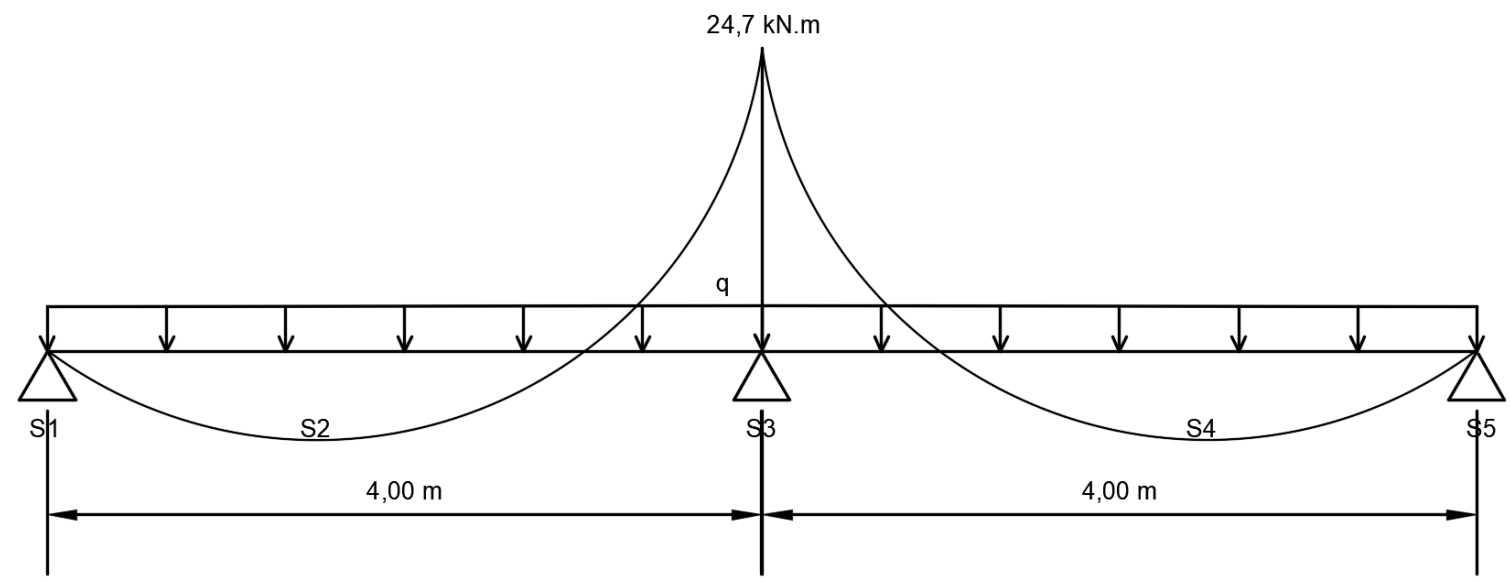

Figura 29 - Diagrama de momentos fletores com o momento resistente de dimensionamento atuando na seção do apoio central.

Para obter a carga distribuída " $\mathrm{q}$ " capaz de gerar o momento fletor de 24,7 kN.m no apoio central é utilizada a equação que fornece o momento fletor em uma viga de um tramo em que uma extremidade está apoiada e a outra está engastada. Calcula-se "q" a partir do momento fletor no engaste.

$$
\begin{gathered}
M_{\text {engaste }}=\frac{q \cdot l^{2}}{8} \\
24,7=\frac{16 \cdot q}{8} \\
q=12,35 \mathrm{kN} / \mathrm{m}
\end{gathered}
$$

Aplicando o carregamento de $12,35 \mathrm{kN} / \mathrm{m}$ na viga, é obtido o diagrama de momentos fletores demonstrado na Figura 30.

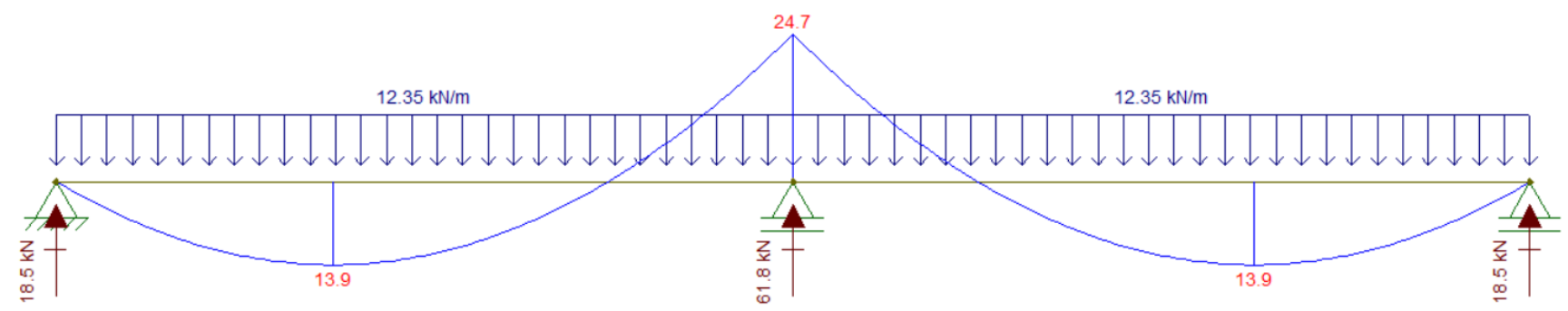

Figura 30 - Diagrama de momentos fletores (kN.m) para o carregamento de 12,35 kN/m aplicado na viga. 
No instante em que o momento fletor de dimensionamento é atingido na seção do apoio central da viga, o aço atinge seu escoamento. A partir desse instante ele adquire ainda uma certa resistência, fazendo com que essa seção ainda seja capaz de suportar um maior valor de momento fletor e as curvaturas continuem aumentando. Dessa maneira, se o concreto apresentar capacidade para aumentar a profundida da linha neutra de modo que a força de compressão possa ser elevada conforme a força de tração na armadura aumenta, maiores valores de binários resistentes são possíveis de ocorrer na seção. Com isso, a viga passa a ser capaz de suportar um carregamento superior ao que foi calculado em regime elástico e a seção transversal segue rotacionando até que um dos materiais (aço ou concreto) atinja uma das suas respectivas deformações limites (3,5\%o para o concreto e $10 \%$ o para o aço).

Para traçar o diagrama de momento-curvatura da seção transversal analisada, é necessário calcular as coordenadas dos pontos A, B, C e D presentes na Figura 27. Para isso, são calculados os momentos de inércia da viga no Estádio I e no Estádio II, além do módulo de elasticidade secante $\left(E_{c s}\right)$ do concreto. Os cálculos dos momentos de inércia da viga nos Estádios I e II foram baseados no livro de CARVALHO e FILHO (2019).

\section{- $\quad$ Cálculo das coordenadas do ponto A}

Para calcular as coordenadas do ponto A é necessário obter o momento fletor de fissuração e a rigidez à flexão $\left(E . I_{I}\right)$ da seção no Estádio I. O cálculo do momento de inércia $\left(I_{I}\right)$ da seção do apoio central da viga no Estádio I, ou seja, sem a seção estar fissurada, é baseado na suposição de que há linearidade entre tensão e deformação e existe aderência perfeita entre a armadura e o concreto. 0 processo de cálculo é melhor visualizado a partir da Figura 31.

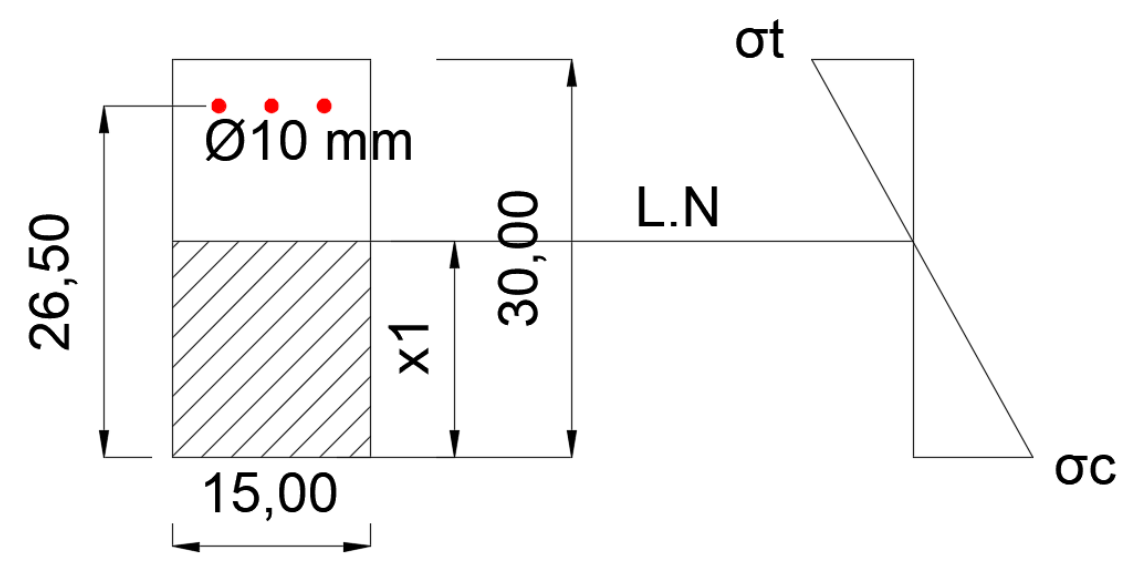

Figura 31 - Seção transversal do apoio central da viga atuando no Estádio I. 
Observando a Figura 31 é possível perceber que a seção é constituída por dois materiais diferentes, portanto, para o cálculo da posição em que se encontra a linha neutra no Estádio I, é necessário homogeneizar essa seção, de forma que a área de aço referente às três barras de $1 \mathrm{~cm}$ de diâmetro seja substituída por uma área equivalente de concreto. Após isso, realiza-se o somatório de momentos estáticos das áreas em relação à linha neutra e iguala-se o resultado a zero. Dessa maneira, a área de concreto equivalente $\left(A_{c, e q}\right)$ é proveniente da multiplicação da área de aço $\left(A_{s}\right)$ por uma relação entre o módulo de elasticidade do aço $\left(E_{s}\right)$ e o módulo de elasticidade do concreto $\left(E_{c}\right)$.

$$
\begin{aligned}
& A_{c, e q}=A_{s} \cdot \frac{E_{s}}{E_{c}} \\
& A_{c, e q}=A_{s} \cdot \alpha_{e}
\end{aligned}
$$

Uma vez que tenha sido calculada a área equivalente de concreto, é possível calcular a posição $\left(x_{1}\right)$ da linha neutra na seção. Esse cálculo é realizado através do somatório de momentos estáticos das áreas em relação à linha neutra, cujo resultado deve ser zero.

$$
\text { b. } x_{1} \cdot \frac{x_{1}}{2}-\left[b .\left(h-x_{1}\right) \cdot \frac{h-x_{1}}{2}\right]-\left[\left(\alpha_{e}-1\right) . A_{s} \cdot\left(d-x_{1}\right)\right]=0
$$

É interessante notar que a área de aço $A_{s}$ é multiplicada por $\left(\alpha_{e}-1\right)$ e não por $\alpha_{e}$. Isso ocorre, pois quando foi considerada a área $b .\left(h-x_{1}\right)$ já foi levado em conta uma vez a área de concreto nos locais onde estão posicionadas as barras da armadura. Dessa maneira, é possível calcular a posição $\left(x_{1}\right)$ da linha neutra para a seção transversal analisada no Estádio I.

$$
\alpha_{e}=\frac{E_{s}}{E_{c}}=\frac{200}{27}=7,4
$$

$$
15 \cdot \frac{x_{1}^{2}}{2}-\left[15 \cdot\left(30-x_{1}\right) \cdot \frac{30-x_{1}}{2}\right]-\left[(7,4-1) \cdot 2,356 \cdot\left(26,5-x_{1}\right)\right]=0
$$




$$
x_{1}=15,37 \mathrm{~cm}
$$

A partir da posição da linha neutra é possível calcular o momento de inércia da seção no Estádio I $\left(I_{I}\right)$. Isso é realizado através dos momentos de inércias das áreas que compõem a seção em relação à linha neutra, utilizando para isso o Teorema dos Eixos Paralelos. Dessa maneira:

$$
I_{I}=\frac{b \cdot h^{3}}{12}+(b \cdot h) \cdot\left(x_{1}-\frac{h}{2}\right)^{2}+\left(\alpha_{e}-1\right) \cdot A_{s} \cdot\left(d-x_{1}\right)^{2}
$$

Foi desconsiderada a parcela de momento de inércia referente às barras de aço, visto que o momento de inércia referente à uma seção circular de $1 \mathrm{~cm}$ de diâmetro é desprezível no resultado. Portanto, no Teorema dos Eixos Paralelos a parcela das barras da armadura que contribui para o momento de inércia $I_{I}$ foi apenas a área multiplicada pela distância do centro de gravidade dessas barras até a linha neutra. Portanto:

$$
\begin{gathered}
I_{I}=\frac{15 \times 30^{3}}{12}+(15 \times 30) \cdot\left(15,37-\frac{30}{2}\right)^{2}+(6,4) \cdot 2,356 \cdot(11,13)^{2} \\
I_{I}=3,57 \times 10^{-4} \mathrm{~m}^{4}
\end{gathered}
$$

Para obter o valor da curvatura $(1 / r)_{c r, I}$ foi obtido o momento fletor $\left(M_{r}\right)$ que leva a peça a fissurar, cujo cálculo se dá de acordo com a NBR 6118:2014 de acordo com:

$$
M_{r}=\frac{\alpha \cdot f_{c t} \cdot I_{c}}{y_{t}}
$$

Em que:

$\alpha=1,5$ para seções retangulares

$f_{c t}=f_{c t k, i n f}$

$I_{C}$ é o momento de inércia da seção bruta de concreto

$y_{t}$ é a distância do centro de gravidade da seção à fibra mais tracionada 
Portanto:

$$
\begin{gathered}
M_{r}=\frac{1,5 \times 0,7 \times 0,3 \times\left(30^{2 / 3}\right) \times 1000 \times \frac{0,15 \times 0,3^{3}}{12}}{0,15} \\
M_{r}=6,84 \mathrm{kN} . \mathrm{m}
\end{gathered}
$$

Dessa maneira, é possível calcular a curvatura $(1 / r)_{c r, I}$ de acordo com:

$$
\left(\frac{1}{r}\right)_{c r, I}=\frac{M_{r}}{E_{c s} \cdot I_{I}}
$$

$E_{c S}$ é dado pela NBR 6118:2014 e para o concreto C-30, $E_{c S}=27$ GPa. Portanto:

$$
\left(\frac{1}{r}\right)_{c r, I}=\frac{6,84}{27000000 \times 3,57 \times 10^{-4}}=7,096 \times 10^{-4} / \mathrm{m}
$$

\section{- $\quad$ Cálculo das coordenadas do ponto B}

Para calcular as coordenadas do ponto B é necessário obter a rigidez à flexão $\left(E . I_{I I}\right)$ da seção no Estádio II. O cálculo do momento de inércia $\left(I_{I I}\right)$ da seção do apoio central da viga no Estádio II, ou seja, com a seção fissurada, é baseado na suposição de que há linearidade entre tensão e deformação e existe aderência perfeita entre a armadura e o concreto. O processo de cálculo é melhor visualizado a partir da Figura 32. 


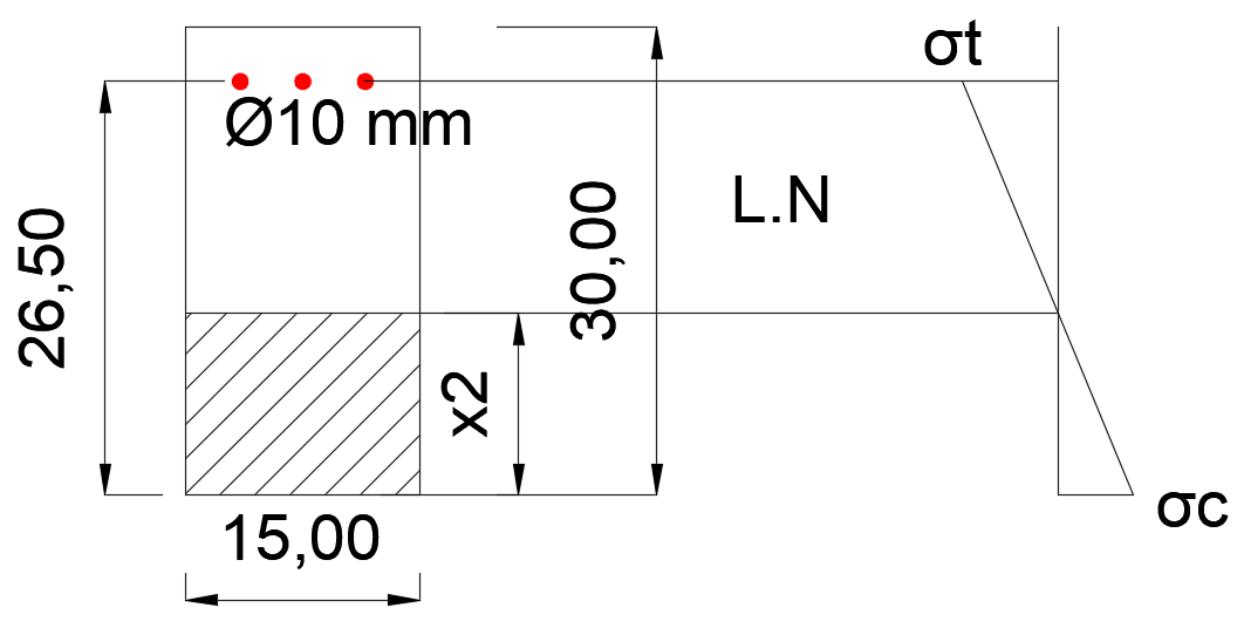

Figura 32 - Seção transversal do apoio central da viga atuando no Estádio II.

Para o cálculo da posição da linha neutra $\left(x_{2}\right)$ da seção no Estádio II realiza-se também o somatório dos momentos estáticos das áreas que compõem a seção, entretanto, no Estádio II não é considerada a parcela de concreto tracionada, visto que a seção se encontra fissurada nesse Estádio. O somatório dos momentos estáticos é então igualado a zero, da mesma forma que foi realizado para o cálculo da posição da linha neutra na seção no Estádio I. Portanto:

$$
\text { b. } x_{2} \cdot \frac{x_{2}}{2}-\left[\left(\alpha_{e} \cdot A_{s}\right) \cdot\left(d-x_{2}\right)\right]=0
$$

Dessa maneira, para a seção analisada a posição da linha neutra pode ser calculada de acordo com:

$$
\begin{gathered}
15 \cdot \frac{x_{2}{ }^{2}}{2}-\left[(7,4 \times 2,356) \times\left(26,5-x_{2}\right)\right]=0 \\
x_{2}=6,77 \mathrm{~cm}=0,0677 \mathrm{~m}
\end{gathered}
$$

O momento de inércia $\left(I_{I I}\right)$ da seção no Estádio II em relação à linha neutra é calculado através do Teorema dos Eixos Paralelos.

$$
I_{I I}=\frac{b \cdot x_{2}{ }^{3}}{12}+\left(b \cdot x_{2}\right) \cdot\left(\frac{x_{2}}{2}\right)^{2}+\left(\alpha_{e} \cdot A_{s}\right) \cdot\left(d-x_{2}\right)^{2}
$$


Portanto, para a seção analisada, o momento de inércia da seção no Estádio II é calculado de acordo com:

$$
\begin{gathered}
I_{I I}=\frac{b \cdot x_{2}{ }^{3}}{12}+\left(b \cdot x_{2}\right) \cdot\left(\frac{x_{2}}{2}\right)^{2}+\left(\alpha_{e} \cdot A_{s}\right) \cdot\left(d-x_{2}\right)^{2} \\
I_{I I}=\frac{15 \times 6,77^{3}}{12}+(15 \times 6,77) \times\left(\frac{6,77}{2}\right)^{2}+(7,4 \times 2,356) \times(26,5-6,77)^{2} \\
I_{I I}=8,34 \times 10^{-5}
\end{gathered}
$$

Dessa maneira, é possível calcular a curvatura $(1 / r)_{c r, I I}$ de acordo com:

$$
\begin{gathered}
\frac{1}{r}=\frac{M_{r}}{E_{c S} \cdot I_{I I}} \\
\left(\frac{1}{r}\right)_{c r, I I}=\frac{6,84}{27000000 \times 8,34 \times 10^{-5}}=3,03 \times 10^{-3} / \mathrm{m}
\end{gathered}
$$

- $\quad$ Cálculo das coordenadas do ponto C

Para calcular as coordenadas do ponto C é necessário utilizar o momento fletor resistente da seção e a deformação $\left(\varepsilon_{y d}\right)$ no aço no início do escoamento.

$$
\begin{gathered}
\varepsilon_{y d}=0,0021739 \\
\varepsilon_{c}=\frac{\varepsilon_{y d} \cdot x}{d-x}
\end{gathered}
$$

Para o momento resistente da seção $x=4,69 \mathrm{~cm}$. 


$$
\begin{gathered}
\varepsilon_{c}=\frac{0,0021739 \times 0,0469}{0,265-0,0469}=4,67 \times 10^{-4} \\
\left(\frac{1}{r}\right)_{y d}=\frac{\varepsilon_{c}+\varepsilon_{y d}}{d} \\
\left(\frac{1}{r}\right)_{y d}=\frac{4,67 \times 10^{-4}+0,0021739}{0,265}=9,967 \times 10^{-3}
\end{gathered}
$$

- $\quad$ Cálculo das coordenadas do ponto D

Para calcular as coordenadas do ponto D é necessário utilizar o momento fletor último da seção, o qual foi calculado utilizando a tensão última do aço de $540 \mathrm{MPa}$, considerada para o CA-50 pela NBR 7480:2007. O binário resistente último é calculado de acordo com:

$$
\begin{gathered}
F_{S}=A_{S} \cdot f_{u d} \\
F_{S}=\left(3 \times \pi \times 0,5^{2}\right) \times \frac{54}{1,15}=110,64 \mathrm{kN} \\
F_{c}=(b \cdot 0,8 x) \cdot 0,85 . f_{c d} \\
110,64=(0,15 \times 0,8 x) \times 0,85 \times \frac{30000}{1,4} \\
110,64=2185,7 x \\
x=0,05062 \mathrm{~m} \rightarrow 5,06 \mathrm{~cm}
\end{gathered}
$$

A partir do valor da profundidade da linha neutra é possível obter o braço de alavanca $z$, que separa a força de tração na armadura e a força de compressão no concreto. 


$$
\begin{gathered}
z=26,5-\frac{5,06}{2}=23,97 \mathrm{~cm} \\
M_{u d}=110,64 \times 0,2397=26,5 \mathrm{kN} . \mathrm{m}
\end{gathered}
$$

A deformação última $\left(\varepsilon_{u d}\right)$ considerada para o aço CA-50 pela NBR 6118:2014 é $\varepsilon_{u d}=10 \%$. Portanto, é possível obter de maneira simplificada o módulo $\left(E_{s h}\right)$ de elasticidade do aço na região plastificada.

$$
\begin{gathered}
E_{s h}=\frac{f_{u d}-f_{y d}}{\varepsilon_{u d}-\varepsilon_{y d}} \\
E_{S h}=\frac{469,56 M P a-434,78 M P a}{0,01-0,0021739} 4444,1 M P a
\end{gathered}
$$

Dessa maneira, na região plastificada, a tensão no aço aumenta de acordo com o módulo de elasticidade $E_{s h}=4444,1 \mathrm{MPa}$. Para traçar o diagrama de momentocurvatura na região plastificada, pode-se adicionar deformações de alongamento ao aço, de forma a obter a força de tração nesse material, o binário resistente na seção e a deformação no concreto. A partir das deformações no aço e no concreto e conhecendo a altura útil d é possível traçar as curvaturas para cada deformada da seção. As deformações atribuídas à seção transversal com os respectivos momentos fletores e curvaturas correspondentes podem ser observados na Tabela 8. Já o diagrama simplificado de momento-curvatura referente à seção transversal analisada está apresentado na Figura 33. 
Tabela 8 - Parâmetros utilizados no cálculo dos momentos fletores e curvaturas da seção transversal em cada um dos trechos do diagrama de momento-curvatura.

\begin{tabular}{|c|c|c|c|c|c|c|c|c|}
\hline$\varepsilon S$ & os (MPa) & $\begin{array}{l}\text { Fsy,k } \\
\text { (kN) }\end{array}$ & $x(m)$ & fc $(k N)$ & $\varepsilon c$ & $z(m)$ & $\begin{array}{c}M \\
(\mathrm{kN} \cdot \mathrm{m})\end{array}$ & $1 / \mathrm{r}$ \\
\hline \multirow{3}{*}{\multicolumn{7}{|c|}{ TRECHO ELÁSTICO (ESTÁDIOS I E II) }} & 0 & 0 \\
\hline & & & & & & & 6.84 & 0.0007096 \\
\hline & & & & & & & 6.84 & 0.003034 \\
\hline 0.00217391 & 434.782609 & 102.435 & 0.04687 & 102.435 & 0.00047 & 0.2416 & 24.7449 & 0.009966 \\
\hline 0.003 & 438.453825 & 103.300 & 0.0473 & 103.300 & 0.00065 & 0.2414 & 24.9 & 0.013778 \\
\hline 0.0032 & 439.342646 & 103.509 & 0.0474 & 103.509 & 0.0007 & 0.2413 & 25.0 & 0.014703 \\
\hline 0.0034 & 440.231466 & 103.719 & 0.0475 & 103.719 & 0.00074 & 0.2413 & 25.0 & 0.015629 \\
\hline 0.0036 & 441.120287 & 103.928 & 0.0475 & 103.928 & 0.00079 & 0.2412 & 25.1 & 0.016555 \\
\hline 0.0038 & 442.009108 & 104.137 & 0.0476 & 104.137 & 0.00083 & 0.2412 & 25.1 & 0.017483 \\
\hline 0.004 & 442.897929 & 104.347 & 0.0477 & 104.347 & 0.00088 & 0.2411 & 25.2 & 0.018411 \\
\hline 0.0042 & 443.786749 & 104.556 & 0.0478 & 104.556 & 0.00093 & 0.2411 & 25.2 & 0.01934 \\
\hline 0.0044 & 444.67557 & 104.766 & 0.0479 & 104.766 & 0.00097 & 0.2410 & 25.3 & 0.02027 \\
\hline 0.0046 & 445.564391 & 104.975 & 0.0480 & 104.975 & 0.00102 & 0.2410 & 25.3 & 0.021201 \\
\hline 0.0048 & 446.453211 & 105.184 & 0.0481 & 105.184 & 0.00107 & 0.2409 & 25.3 & 0.022132 \\
\hline 0.005 & 447.342032 & 105.394 & 0.0482 & 105.394 & 0.00111 & 0.2409 & 25.4 & 0.023065 \\
\hline 0.0052 & 448.230853 & 105.603 & 0.0483 & 105.603 & 0.00116 & 0.2408 & 25.4 & 0.023998 \\
\hline 0.0054 & 449.119674 & 105.813 & 0.0484 & 105.813 & 0.00121 & 0.2408 & 25.5 & 0.024932 \\
\hline 0.0056 & 450.008494 & 106.022 & 0.0485 & 106.022 & 0.00125 & 0.2407 & 25.5 & 0.025867 \\
\hline 0.0058 & 450.897315 & 106.231 & 0.0486 & 106.231 & 0.0013 & 0.2407 & 25.6 & 0.026803 \\
\hline 0.006 & 451.786136 & 106.441 & 0.0487 & 106.441 & 0.00135 & 0.2407 & 25.6 & 0.027739 \\
\hline 0.0062 & 452.674957 & 106.650 & 0.0488 & 106.650 & 0.0014 & 0.2406 & 25.7 & 0.028676 \\
\hline 0.0064 & 453.563777 & 106.860 & 0.0489 & 106.860 & 0.00145 & 0.2406 & 25.7 & 0.029615 \\
\hline 0.0066 & 454.452598 & 107.069 & 0.0490 & 107.069 & 0.0015 & 0.2405 & 25.8 & 0.030554 \\
\hline 递 0.0068 & 455.341419 & 107.278 & 0.0491 & 107.278 & 0.00155 & 0.2405 & 25.8 & 0.031493 \\
\hline 0.007 & 456.23024 & 107.488 & 0.0492 & 107.488 & 0.0016 & 0.2404 & 25.8 & 0.032434 \\
\hline 0.0072 & 457.11906 & 107.697 & 0.0493 & 107.697 & 0.00164 & 0.2404 & 25.9 & 0.033376 \\
\hline 0.0074 & 458.007881 & 107.907 & 0.0494 & 107.907 & 0.00169 & 0.2403 & 25.9 & 0.034318 \\
\hline 0.0076 & 458.896702 & 108.116 & 0.0495 & 108.116 & 0.00174 & 0.2403 & 26.0 & 0.035261 \\
\hline 0.0078 & 459.785523 & 108.325 & 0.0496 & 108.325 & 0.00179 & 0.2402 & 26.0 & 0.036205 \\
\hline 0.008 & 460.674343 & 108.535 & 0.0497 & 108.535 & 0.00184 & 0.2402 & 26.1 & 0.03715 \\
\hline 0.0082 & 461.563164 & 108.744 & 0.0498 & 108.744 & 0.0019 & 0.2401 & 26.1 & 0.038096 \\
\hline 0.0084 & 462.451985 & 108.954 & 0.0498 & 108.954 & 0.00195 & 0.2401 & 26.2 & 0.039042 \\
\hline 0.0086 & 463.340806 & 109.163 & 0.0499 & 109.163 & 0.002 & 0.2400 & 26.2 & 0.03999 \\
\hline 0.0088 & 464.229626 & 109.372 & 0.0500 & 109.372 & 0.00205 & 0.2400 & 26.2 & 0.040938 \\
\hline 0.009 & 465.118447 & 109.582 & 0.0501 & 109.582 & 0.0021 & 0.2399 & 26.3 & 0.041887 \\
\hline 0.0092 & 466.007268 & 109.791 & 0.0502 & 109.791 & 0.00215 & 0.2399 & 26.3 & 0.042837 \\
\hline 0.0094 & 466.896089 & 110.001 & 0.0503 & 110.001 & 0.0022 & 0.2398 & 26.4 & 0.043788 \\
\hline 0.0096 & 467.784909 & 110.210 & 0.0504 & 110.210 & 0.00226 & 0.2398 & 26.4 & 0.044739 \\
\hline 0.0098 & 468.67373 & 110.420 & 0.0505 & 110.420 & 0.00231 & 0.2397 & 26.5 & 0.045692 \\
\hline 0.01 & 469.562551 & 110.629 & 0.0506 & 110.629 & 0.00236 & 0.2397 & 26.5 & 0.046645 \\
\hline
\end{tabular}




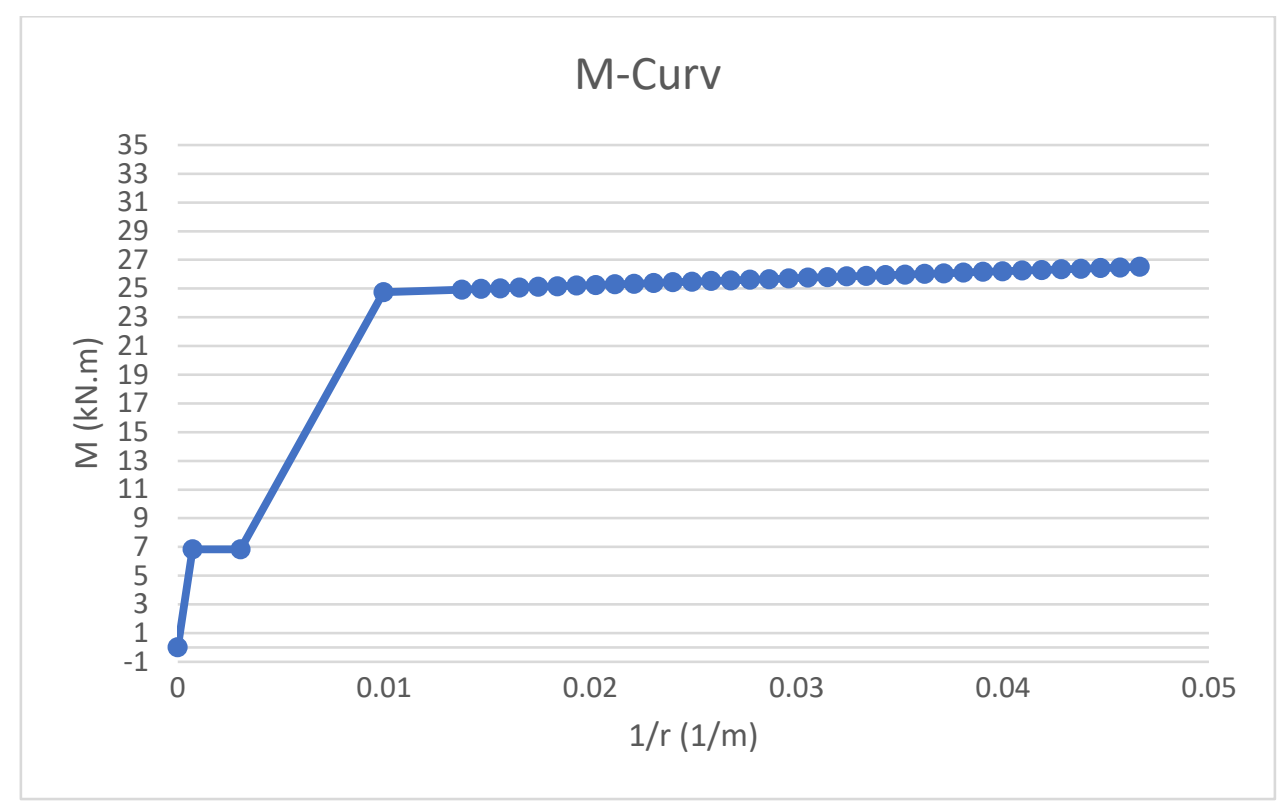

Figura 33 - Diagrama de momento-curvatura simplificado para a seção transversal analisada.

O cálculo da capacidade de rotação plástica é então proveniente da curvatura última da seção e a curvatura no instante em que o aço atinge o escoamento. Segundo BUCHAIM (2016), a capacidade de rotação plástica pode ser calculada de acordo com:

$$
\theta_{p l}=\alpha_{y} \cdot\left(\frac{1}{r} u d-\frac{1}{r} y d\right)
$$

sendo:

$\alpha_{y}$ é a extensão plastificada em cada lado do apoio de continuidade. Adotado por BUCHAIM (2016) como sendo 0,6. $h$, onde $h$ é a altura da seção transversal.

$$
\theta_{p l}=0,6 \times 0,3 \times(0,046645-0,009966)=0,006602
$$

De posse da capacidade de rotação plástica, é possível verificar se a seção transversal em análise apresenta possibilidade de rotacionar em regime plástico a ponto de redistribuir os esforços na viga e romper com um carregamento superior a aquele que gera o momento resistente na seção em regime elástico. A viga em análise, apresentada na Figura 28 pode ter o seu primeiro tramo analisado de acordo com o modelo estático demonstrado na Figura 34. 


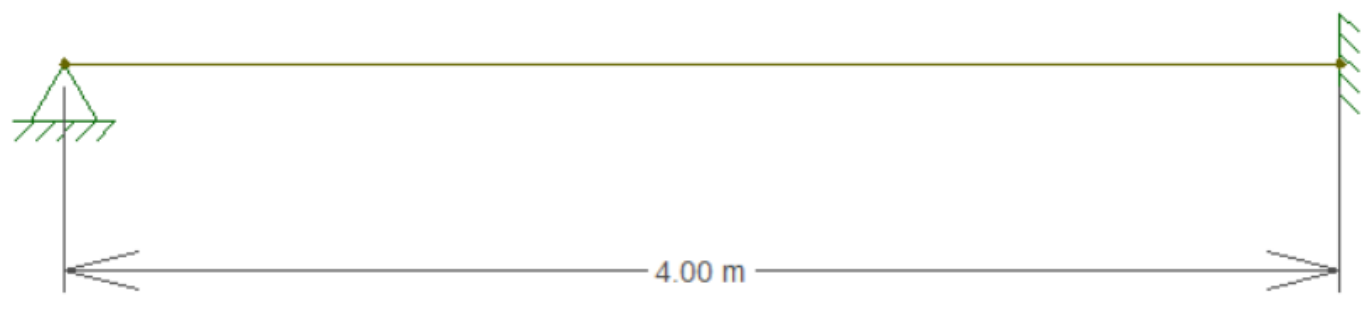

Figura 34 - Sistema estático equivalente para o primeiro tramo da viga analisada.

Esse sistema estático equivalente, quando submetido ao carregamento de 12,35 $\mathrm{kN} / \mathrm{m}$ resulta nos mesmos valores de momentos fletores apresentados na viga quando esta é analisada por inteiro. Esses resultados estão ilustrados na Figura 35.

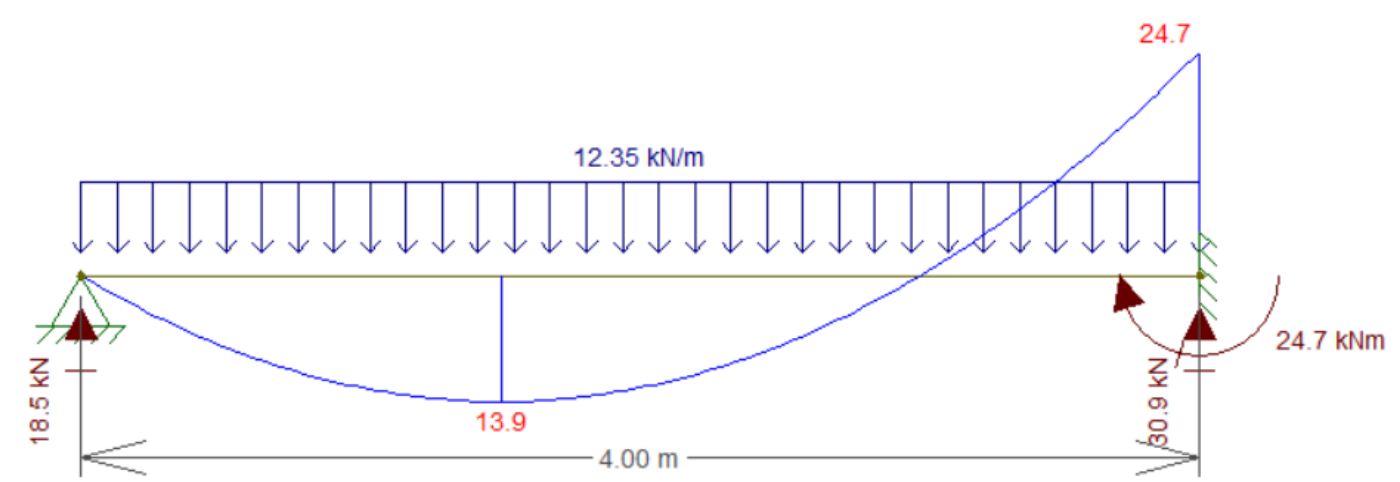

Figura 35 - Resultados de momentos fletores ao longo do sistema equivalente para o primeiro tramo da viga analisada.

Sendo o ângulo de rotação $\theta$ definido como o ângulo entre o eixo x e a tangente à curva de deflexão, para estruturas com ângulo de rotação, deflexões e curvatura muito pequenos é possível relacionar esse ângulo $\theta$ com a curvatura $1 / r$ da seguinte forma:

$$
\begin{gathered}
\frac{1}{r}=\frac{d \theta}{d x} \\
\theta=\int_{0}^{x} \frac{1}{r} d x
\end{gathered}
$$

A partir da Resistência dos Materiais, é possível também relacionar a curvatura com o momento fletor de acordo com: 


$$
\frac{1}{r}=\frac{M}{(E I)_{\text {elástico }}}
$$

sendo:

$M$ é o momento fletor atuante na seção transversal;

$(E I)_{\text {elástico }}$ rigidez à flexão em regime elástico.

Através do diagrama de momento-curvatura, é possível, portanto, obter a rigidez à flexão no regime elástico, ou seja, antes da seção atingir a plastificação. Isso pode ser realizado desconsiderando nesse diagrama o trecho em que a seção está atuando no Estádio I sem fissura e conectando a origem do gráfico ao ponto do momento de plastificação. A rigidez à flexão em regime elástico é então o coeficiente angular desta reta. O diagrama de momento curvatura desconsiderando o Domínio I pode ser observado na Figura 36.

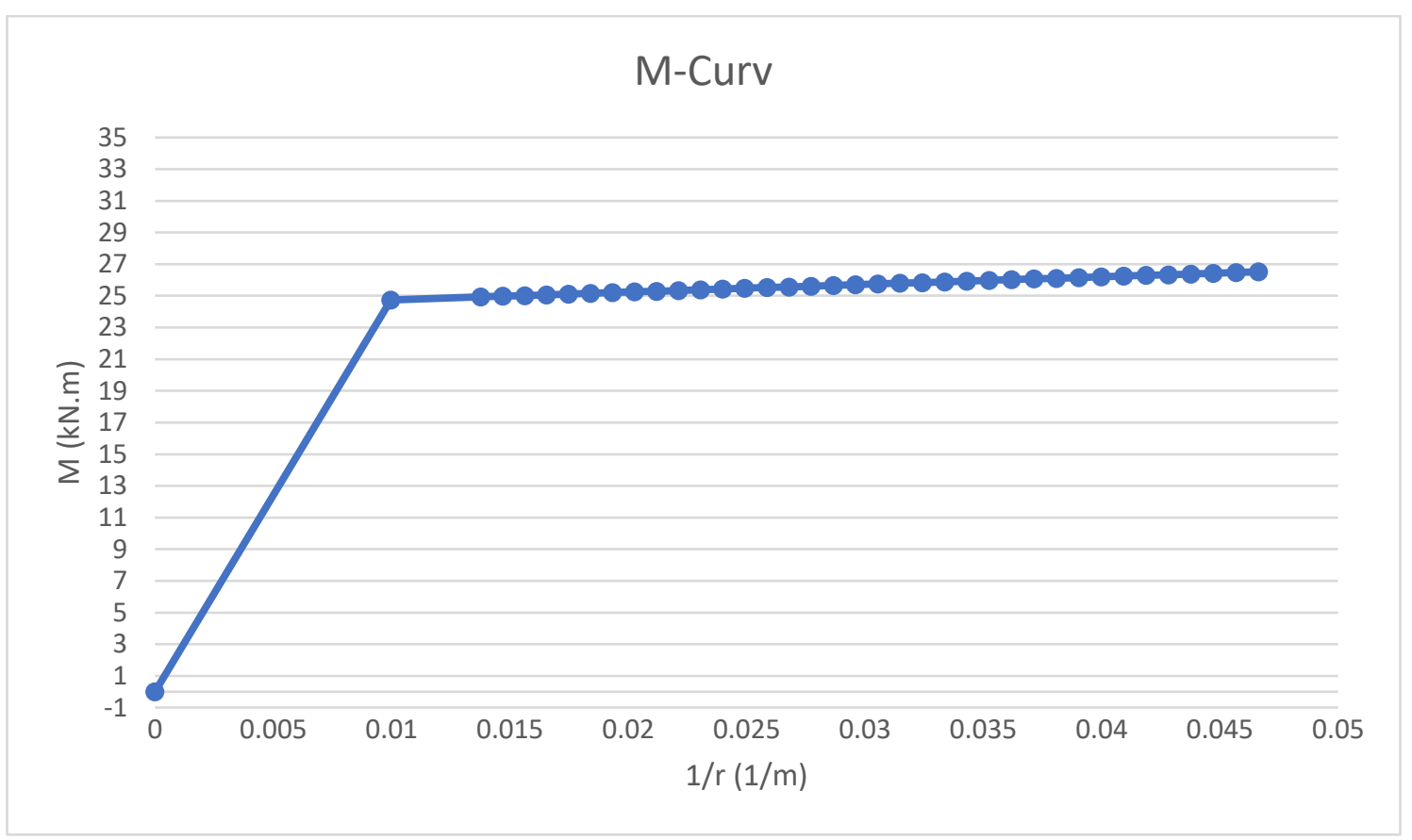

Figura 36 - Diagrama de momento-curvatura desconsiderando o Domínio I.

De posse das coordenadas do ponto referente ao momento fletor de plastificação, ou seja, no instante em que o aço atinge o escoamento, é possível calcular a rigidez à flexão em regime elástico. Portanto: 


$$
\begin{gathered}
0.00996593=\frac{24,7}{(E I)_{\text {elástico }}} \\
(E I)_{\text {elástico }}=2482,95 \mathrm{kN} . \mathrm{m}^{2}
\end{gathered}
$$

Utilizando o princípio da superposição, é possível dividir o sistema estático equivalente em uma viga biapoiada com um carregamento uniformemente distribuído e uma viga biapoiada com um momento fletor aplicado igual ao momento fletor que surge no engaste para aquele carregamento uniformemente distribuído. As reações de apoio e momento fletor dados por um carregamento uniformemente distribuído aplicado na viga que representa o sistema estático equivalente podem ser observados na Figura 37.

$$
M=\frac{q \cdot L^{2}}{8}
$$

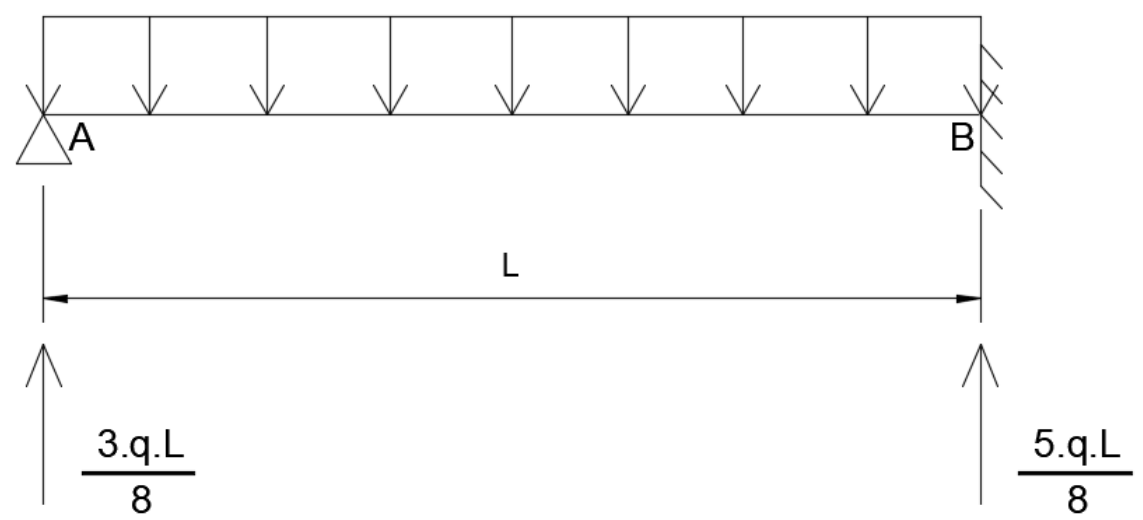

Figura 37 - Reações de apoio e momento fletor dados por um carregamento uniformemente distribuído aplicado na viga que representa o sistema estático equivalente.

A partir da Resistência dos Materiais, a rotação do apoio B para a viga biapoiada com carregamento q uniformemente distribuído resulta em:

$$
\begin{gathered}
M(x)=\frac{q l x}{2}-\frac{q x^{2}}{2} \\
E I \theta=\int \frac{q l x}{2}-\frac{q x^{2}}{2} d x
\end{gathered}
$$




$$
E I \theta=\frac{q l x^{2}}{4}-\frac{q x^{3}}{6}+C
$$

Se $x=l / 2$, então $\theta=0$, logo:

$$
\begin{gathered}
0=\frac{q l^{3}}{16}-\frac{q l^{3}}{48}+C \\
C=\frac{q l^{3}}{48}-\frac{q l^{3}}{16}=\frac{q l^{3}-3 q l^{3}}{48}=\frac{-2 q l^{3}}{48} \\
C=\frac{-q l^{3}}{24} \\
\theta=\frac{q l x^{2}}{4 E I}-\frac{q x^{3}}{6 E I}-\frac{q l^{3}}{24 E I}
\end{gathered}
$$

Para $x=l$, ou seja, a rotação no apoio onde é o engaste no sistema estático equivalente:

$$
\begin{aligned}
& \theta=\frac{q l^{3}}{4 E I}-\frac{q l^{3}}{6 E I}-\frac{q l^{3}}{24 E I} \\
& \theta=\frac{6 q l^{3}-4 q l^{3}-q l^{3}}{24 E I}
\end{aligned}
$$

$$
\theta=\frac{q l^{3}}{24 E I}
$$

Da mesma maneira que foi calculada a rotação do apoio B considerando o carregamento uniformemente distribuído no sistema estático equivalente, a rotação desse mesmo apoio ao considerar o momento fletor aplicado é calculado de acordo com:

$$
\theta=\frac{-M l}{3 E I}
$$

Portanto, a rotação total no apoio B é dada de acordo com: 


$$
\theta=\frac{q l^{3}}{24 E I}-\frac{M l}{3 E I}
$$

É importante compreender nesse momento, que a rotação do apoio B quando a peça se encontra no regime elástico é igual a zero. Portanto, a equação da rotação no apoio $B$ para a viga no regime elástico resulta no valor do próprio momento fletor que ocorre no engaste para um carregamento uniformemente distribuído.

$$
\begin{gathered}
0=\frac{q l^{3}}{24 E I}-\frac{M l}{3 E I} \\
\frac{q l^{3}}{24 E I}=\frac{M l}{3 E I} \\
M=\frac{q l^{2}}{8}
\end{gathered}
$$

Entretanto, após o aço atingir o escoamento, a seção transversal passa a rotacionar em regime plástico até que um dos materiais (aço ou concreto) atinja sua deformação limite e a peça atinja a ruptura. Durante a rotação plástica, a seção transversal rotaciona sem absorver praticamente nenhum momento fletor adicional, de maneira que mesmo com acréscimo de carregamento, a seção permanece equilibrando momentos fletores próximos ao momento fletor de plastificação. O carregamento que leva a peça ao rompimento, além do qual a estrutura foi dimensionada, pode ser calculado a partir da capacidade de rotação plástica da seção transversal.

$$
\begin{gathered}
\frac{q l^{3}}{24 E I}-\frac{M l}{3 E I}=0,006602 \\
\frac{q \times 4^{3}}{24 \times 2482,95}-\frac{24,7 \times 4}{3 \times 2482,95}=0,006602 \\
1,074 \times 10^{-3}(q)-0,01326=0,006602 \\
q=18,5 \mathrm{kN} / \mathrm{m}
\end{gathered}
$$


Portanto, o carregamento que leva a viga em análise ao colapso é $18,5 \mathrm{kN} / \mathrm{m}$, ou seja, valor este superior ao carregamento de $12,35 \mathrm{kN} / \mathrm{m}$ no qual a viga foi dimensionada. Aplicando o novo carregamento na viga em questão, tem-se um novo valor de momento fletor calculado pela Equação 5.62 a ser considerado no engaste da viga equivalente de um tramo com uma extremidade apoiada e outra extremidade engastada. Esse novo valor é de $37,0 \mathrm{kN}$.m. O coeficiente de redistribuição dos esforços $(\delta)$ pode ser calculado então de acordo com:

$$
\delta=\frac{24,7}{37,0}=0,667 \cong 0,67
$$

A NBR 6118:2014 indica que quando for efetuada uma redistribuição, reduzindose um momento fletor de $M$ para $\delta M$, em uma determinada seção transversal, a profundidade da linha neutra nessa seção $\mathrm{x} / \mathrm{d}$, para o momento reduzido $\delta M$, deve ser limitada por:

$$
\frac{x}{d} \leq \frac{\delta-0,44}{1,25}
$$

Além disso a norma também estabelece que $x / d \leq 0,45$ para concretos com $f_{c k} \leq 50 M P a$. Portanto:

$$
\frac{x}{d} \leq \frac{0,67-0,44}{1,25}=0,184
$$

Para a viga analisada tem-se que $x / d=0,23$ para o momento fletor de escoamento das armaduras para o qual a viga é dimensionada no ELU. Isso demonstra que apesar do método utilizado para o cálculo da rotação plástica indicar que a seção transversal da viga é capaz de suportar um momento de 37,0 kN.m considerando sua rotação plástica, por estabelecimento da NBR 6118:2014 esse valor deve ser menor. O cálculo do coeficiente de redistribuição permitido pela norma se dá de acordo com:

$$
0,23=\frac{\delta-0,44}{1,25}
$$




$$
\delta=0,73
$$

Portanto, o máximo momento fletor que pode atuar na seção transversal da viga analisada de acordo com a NBR 6118:2014 de forma que essa seção seja capaz de rotacionar e redistribuir os esforços ao longo da viga é de:

$$
M_{d 0}=\frac{24,7}{0,73}=33,8 \mathrm{kN} \cdot \mathrm{m}
$$

Esse valor de momento fletor está relacionado ao carregamento uniformemente distribuído de 16,9kN/m de acordo com a Equação 5.62.

\section{4 .}

\section{Carregamento último para a viga reforçada com barras de PRFC}

O reforço composto por barras de polímero reforçado com fibras de carbono (PRFC) é um material que apresenta comportamento elástico até a ruptura. Dessa maneira, não há rotação plástica da seção transversal para conferir uma redistribuição de esforços na viga. Neste item é realizada uma verificação do carregamento que romperia a mesma viga analisada na Figura 28 , porém desta vez utilizando barras de PRFC com mesmo diâmetro das barras de aço utilizadas anteriormente na seção anterior. Inicialmente é calculada a taxa balanceada de armadura para as barras de PRFC utilizadas.

$$
\begin{gathered}
\rho_{f b}=0,85 \beta_{1} \frac{f_{c}^{\prime}}{f_{f u}} \frac{E_{f} \varepsilon_{c u}}{E_{f} \varepsilon_{c u}+f_{f u}} \\
\rho_{f b}=0,85 \times 0,85 \frac{30}{2070} \frac{152000 \times 0,003}{152000 \times 0,003+2070}=0,00189 \\
1,4 . \rho_{f b}=1,4 \times 0,00189=0,00265
\end{gathered}
$$

Uma vez que tenha sido calculada a taxa balanceada de reforço, calculou-se a taxa de armadura existente na viga considerando 3 barras de $10 \mathrm{~mm}$ de diâmetro e seção transversal retangular de $15 \mathrm{~cm} \times 30 \mathrm{~cm}$. 


$$
\rho_{f}=\frac{3 \times\left(\pi \times 0,5^{2}\right)}{15 \times 30}=0,00524
$$

Portanto, $\rho_{f}>1,4 \rho_{f b}$, logo, a viga está dimensionada para romper por falha do concreto. Dessa maneira, a tensão nas barras pode ser calculada por:

$$
\begin{gathered}
f_{f}=\left(\sqrt{\frac{(456)^{2}}{4}+\frac{0,85 \times 0,85 \times 30}{0,00524} \times 456}-0,5 \times 456\right) \leq 2070 \\
f_{f}=1164,2 \mathrm{MPa}
\end{gathered}
$$

Após o cálculo da tensão no reforço, pode-se calcular a capacidade de momento resistente que essa seção transversal apresenta.

$$
\begin{gathered}
f_{f}=1164,2 \mathrm{MPa} \\
\rho_{f} \cdot f_{f}=0,00524 \times 1164200=6100,408 \mathrm{kN} / \mathrm{m}^{2} \\
M_{n}=6100,408 \times\left(1-0,59 \times \frac{6100,408}{30000}\right) \times 0,15 \times 0,265^{2} \\
M_{n}=56,55 \mathrm{kN} . \mathrm{m}
\end{gathered}
$$

Aplicando o coeficiente de redução da capacidade nominal de resistência à flexão para o caso em que $\rho_{f}>1,4 . \rho_{f b}$, é possível calcular o momento último de projeto que essa seção transversal é capaz de suportar para essa taxa de armadura com barras de PRFC.

$$
\begin{gathered}
0,65 \times 56,55 \geq M_{u} \\
0,65 \times 56,55=36,7 \mathrm{kN} . \mathrm{m}
\end{gathered}
$$

O cálculo demonstrou que uma viga com as características da viga apresentada na Figura 28 em que a armadura longitudinal de reforço é composta por 3 barras com 10 
mm de diâmetro de PRFC suporta um momento fletor de 36,7 kN.m. Conforme a viga da Figura 28 é submetida a um carregamento uniformemente distribuído, o maior valor de momento fletor ocorre no apoio central. Para obter a carga distribuída " $q$ " capaz de gerar o momento fletor de $36,7 \mathrm{kN} . \mathrm{m}$ nesse apoio é utilizada a equação que fornece o momento fletor em uma viga de um tramo em que uma extremidade está apoiada e a outra está engastada. Calcula-se " $q$ " a partir do momento fletor no engaste.

$$
36,7=\frac{q \cdot 4^{2}}{8}=18,35 \mathrm{kN} / \mathrm{m}
$$

A Figura 38 apresenta a viga da Figura 28 submetida ao carregamento de 18,35 $\mathrm{kN} / \mathrm{m}$ e o diagrama de momentos fletores resultante.

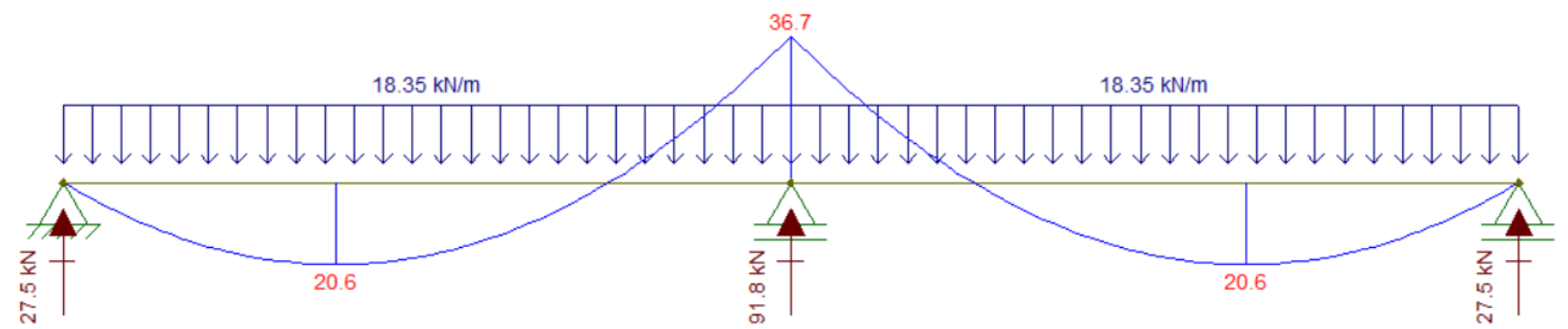

Figura 38 - Momentos fletores para a viga submetida ao carregamento uniformemente distribuído de $18,35 \mathrm{kN} / \mathrm{m}$.

5.5 .

\section{Análise dos resultados}

Neste capítulo foi realizado o dimensionamento da armadura de flexão para uma seção de viga de concreto armado reforçada com barras de aço ou barras de PRFC considerando um momento fletor de dimensionamento igual ao dobro do momento fletor mínimo dado pela NBR 6118:2014. A armadura resultante da utilização do aço como reforço é aproximadamente 2,05 vezes superior a aquela constituída por barras de PRFC quando o dimensionamento utilizando a armadura de PRFC ocorre considerando o processo de ruptura da viga governado pelo concreto e 2,7 vezes superior quando esse processo é governado pela ruptura do reforço.

Foi analisado também o carregamento uniformemente distribuído que efetivamente rompe a viga contínua apresentada na Figura 28 quando esta é reforçada à flexão com três barras de aço com $10 \mathrm{~mm}$ de diâmetro e quando é reforçada com barras 
de PRFC também com $10 \mathrm{~mm}$ de diâmetro. O cálculo demonstrou que para o caso analisado, os valores de carregamentos que rompem a viga considerando cada um dos tipos de armaduras foram 18,5 kN/m para a viga reforçada com barras de aço e 18,35 $\mathrm{kN} / \mathrm{m}$ para a viga reforçada com barras de PRFC. No entanto, por limitações da NBR 6118:2014 em relação à redistribuição de esforços, o máximo carregamento uniformemente distribuído permitido na viga é de $16,9 \mathrm{kN} / \mathrm{m}$.

Dessa maneira, é possível observar que para o caso analisado, o carregamento que leva a viga reforçada com barras de aço à ruptura é aproximadamente $8,6 \%$ inferior ao carregamento que leva esta mesma viga a romper quando a armadura de reforço é constituída por barras de PRFC. É interessante ressaltar a importância da ductilidade capaz de existir em uma seção de concreto armado reforçada com barras de aço, pois apesar do momento fletor de dimensionamento ser de 24,7 kN.m, essa seção é capaz de suportar um momento fletor de $33,8 \mathrm{kN} . \mathrm{m}$ (36,8\% superior) ao ser considerada a sua capacidade de rotacionar e redistribuir esforços. Portanto, para o caso analisado, apesar das barras de PRFC apresentarem resistência à tração substancialmente superior ao aço, o carregamento que efetivamente rompe a viga não difere mais que $10 \%$ quando a viga é reforçada com barras de aço e quando é reforçada com armadura de PRFC. 


\section{6.}

\section{Análise de custos}

Foi realizada uma busca pelo custo relacionado às barras de aço comumente utilizadas para reforço das estruturas de concreto comparado ao custo das barras de polímero reforçado com fibras de carbono para este mesmo fim. É interessante notar que não foram encontrados dados a respeito de barras de polímero reforçado com fibras de carbono produzidas no Brasil, tendo sido identificadas apenas barras desse tipo provenientes da China, tornando bastante complicada a obtenção dos custos relacionados a este produto. A Figura 39 apresenta um exemplo obtido para o preço por metro da barra de polímero reforçado com fibra de carbono, enquanto a Figura 40 apresenta as especificações dessa barra.

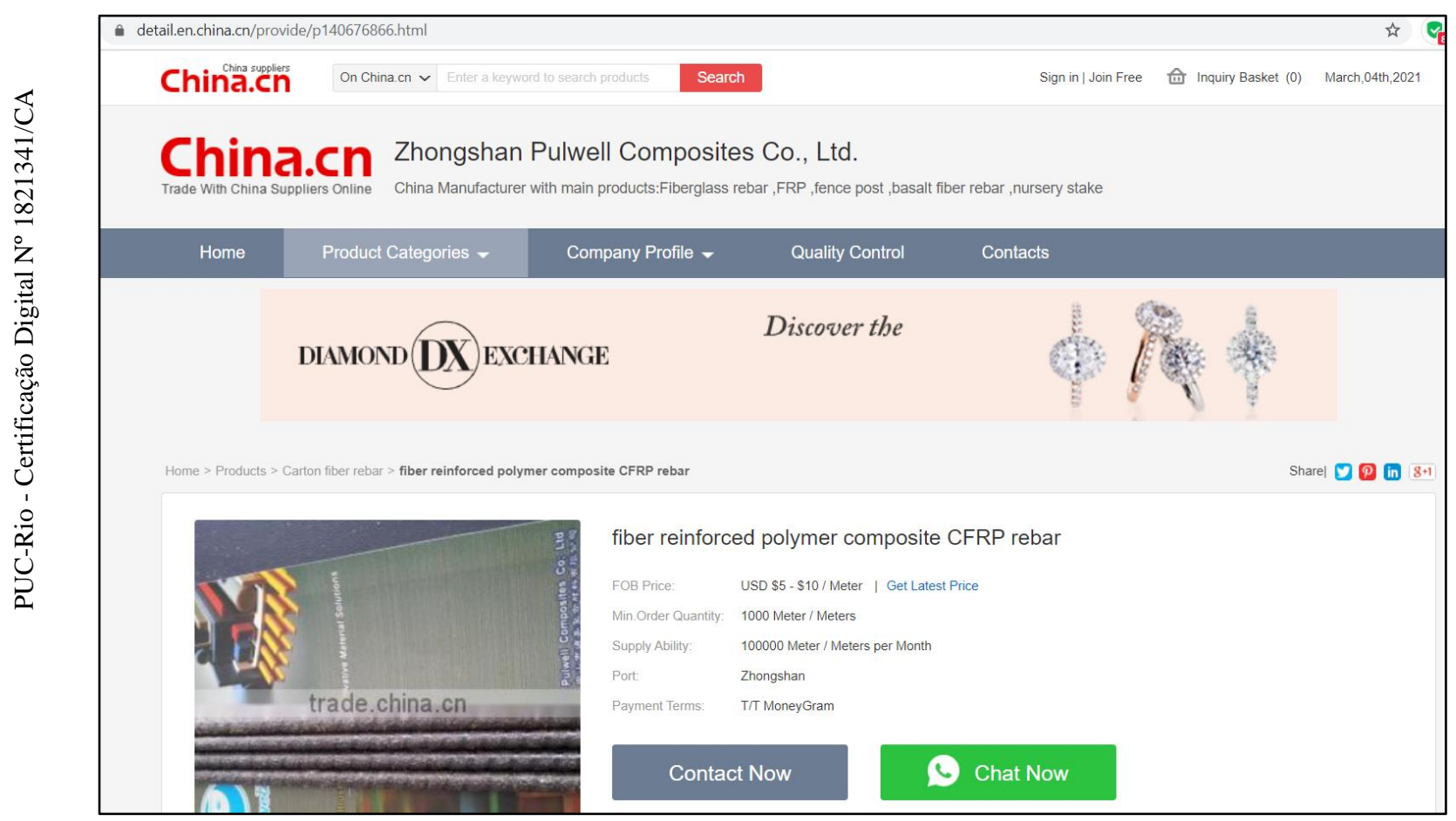

Figura 39 - Preço por metro da barra de polímero reforçado com fibra de carbono. Fonte: https://detail.en.china.cn/provide/p140676866.html. 


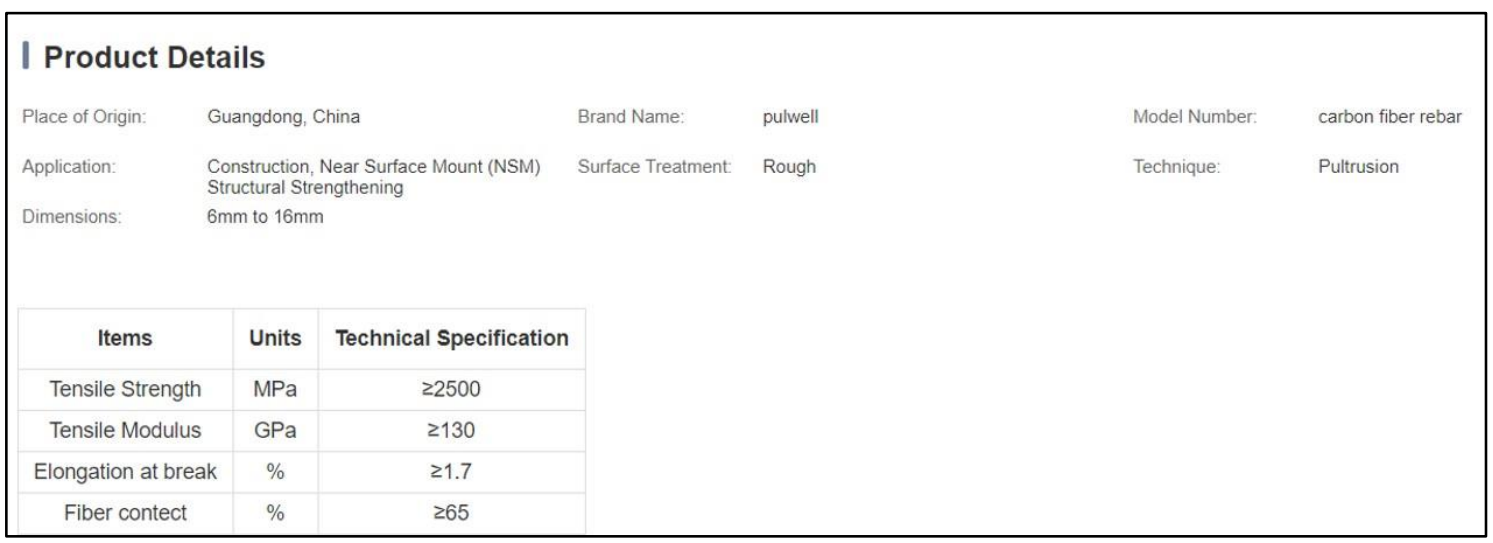

Figura 40 - Especificações da barra de polímero reforçado com fibras de carbono apresentada na Figura 39. Fonte: https://detail.en.china.cn/provide/p140676866.html.

Um segundo exemplo de barra de polímero reforçado com fibra de carbono pode ser observado na Figura 41, não tendo sido possível encontrar o preço desta barra.

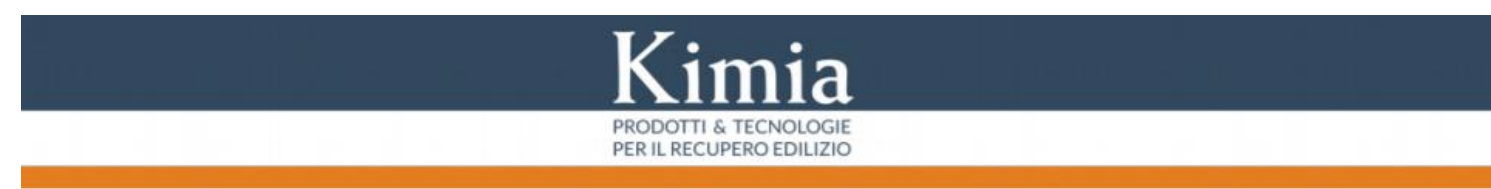

\section{Kimitech TONDO CB}

ST3-0217

Carbon reinforcing bars

\section{DESCRIPTION}

Kimitech TONDO CB is a structural element with a full circular section, available in several diameters, supplied in standard bars of 2 meters, composed of unidirectional carbon fibers impregnated with synthetic resins.

It is not influenced by stray and electromagnetic currents and has very high resistance to corrosion.

\section{USES}

Kimitech TONDO CB carbon reinforcing bars can be used for end anchorings and anti-delamination connectors for composite systems and, in general, for nailing and microcrimping (in combination with Kimitech resins, cementitious products Betonfix or lime based Limepor). Kimitech TONDO CB bars are used as reinforcement in

\begin{tabular}{|l|l|}
\hline \multicolumn{1}{|c|}{ Characteristics } & \multicolumn{1}{|c|}{ Tipical data } \\
\hline Specific weight & $1.6 \mathrm{~g} / \mathrm{cm}$ \\
\hline Fibre content & $60 \%$ \\
\hline Tensile elongation at failure & $1.9 \%$ \\
\hline Tensile elastic modulus & $130 \mathrm{GPa}$ \\
\hline Tensile strength & $2300 \mathrm{MPa}$ \\
\hline Limit operating temperature & $-30 /+70^{\circ} \mathrm{C}$ \\
\hline Color & Black \\
\hline & \\
& \\
STORAGE \\
Strne the nrndint in a sheltered and dru nlare In these
\end{tabular}

Figura 41 - Exemplo de barra de polímero reforçado com fibras de carbono. Fonte:

https://www.kimia.it/sites/default/files/docs/st/en-kimitech-tondo-cb.pdf. 
Os dois exemplos de barras de polímero reforçado com fibras de carbono apresentados possuem características mecânicas bastante semelhantes. No primeiro exemplo, as barras possuem tensão de resistência à tração igual ou superior a $2500 \mathrm{MPa}$ e módulo de elasticidade igual ou superior a $130 \mathrm{GPa}$. Para o segundo exemplo, as barras apresentam tensão resistente à tração igual a $2300 \mathrm{MPa}$ e módulo de elasticidade de 130 GPa. O preço encontrado para a primeira barra varia entre U\$ 5,00 e U\$ 10,00 por metro, ressaltando que essas barras podem ser disponibilizadas com diversos diâmetros (entre 6 mm e $16 \mathrm{~mm}$ ) segundo informações do site de referência.

Em relação às barras de aço, não há dificuldades em se encontrar custos e opções no Brasil e dessa maneira, a Figura 42 apresenta um exemplo de barra de aço CA-50 com diâmetro de $10 \mathrm{~mm}$ e seu custo. É verificado que o custo apresentado se dá para o comprimento de $12 \mathrm{~m}$ de barra, ou seja, para calcular o preço por metro é necessário dividir o valor por 12

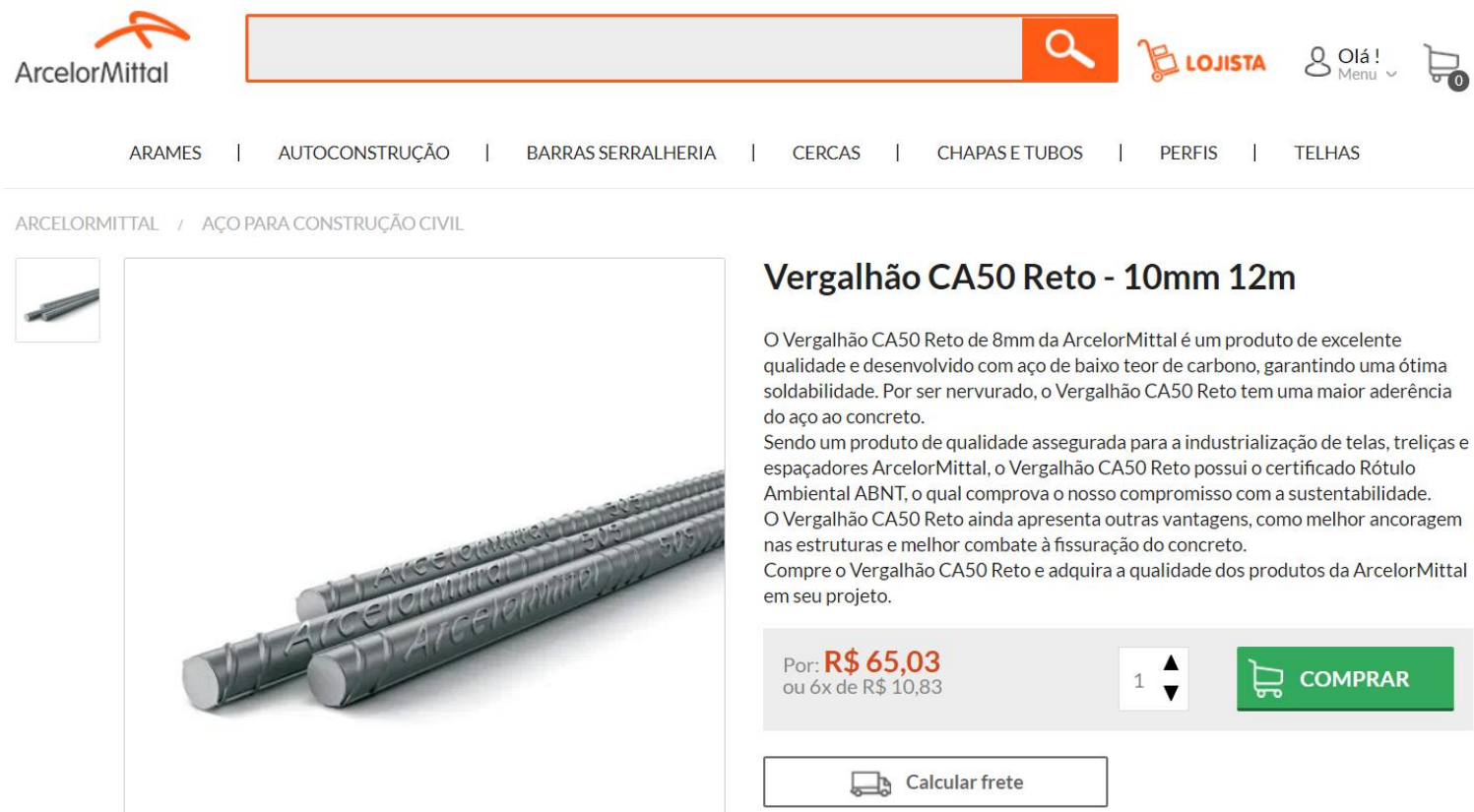

Figura 42 - Exemplo de barra de aço para reforço de estruturas de concreto. Fonte:

https://loja.arcelormittal.com.br/vergalhao-ca50-10-00-mmreto-12-metros/p.

Portanto, o preço por metro da barra de aço referente ao exemplo apresentado se dá de acordo com:

$$
\operatorname{Preço~}_{/ m}=\frac{65,03}{12}=R \$ 5,42 / m
$$


Desta maneira, é interessante notar que o preço da barra de aço e da barra de polímero reforçado com fibras de carbono apresentam uma diferença bastante considerável. Entretanto, isso não é decorrente do valor em si, mas da relação entre o dólar e o real, a qual no presente momento em que este trabalho está sendo desenvolvido na data de $08 / 03 / 2021$ é de $U \$ 1,00=R \$ 5,78$. Observando a faixa de valores na qual a barra de polímero reforçado com fibras de carbono está inserida, é possível considerar na análise o valor de $U \$ 5,00 / m$, ou seja, levando em conta a conversão do dólar para o real na presente data, o custo da barra de polímero reforçado com fibra de carbono por metro é de aproximadamente seis vezes superior ao custo da barra de aço por metro. Isso prejudica, portanto, a utilização da barra de polímero reforçado com fibra de carbono para o reforço das estruturas de concreto, visto que pelo fato desse material não ser fabricado no Brasil, o seu custo passa a ser consideravelmente maior do que a utilização das barras usuais de aço. 


\section{7.}

\section{Conclusões e sugestões para estudos futuros}

O presente trabalho abordou a utilização de barras de polímero reforçado com fibras de carbono (PRFC) para o reforço de vigas de concreto. Inicialmente foi realizada uma análise não linear por meio do software Atena, simulando um ensaio de flexão por quatro pontos para duas vigas (BRC1 e BRC2) de concreto reforçadas com barras de PRFC. Os resultados gerados pelo software foram comparados com aqueles obtidos por RAFI et al (2007) em experimentos de laboratório. Essa análise demonstrou que as cargas que levaram as vigas ao colapso apresentaram a mesma ordem de grandeza tanto para as vigas ensaiadas em laboratório quanto para essas vigas simuladas no Atena. A viga BRC1 apresentou a deflexão máxima de 82\% daquela registrada em laboratório e a viga BRC2 um valor de $76 \%$ daquele obtido em laboratório. As tensões máximas obtidas nas barras de PRFC através das simulações realizadas no Atena foram de $80 \%$ da tensão de resistência na viga BRC1 e 72,7\% da tensão resistente na viga BRC2. Nos ensaios de laboratório os autores registraram para essas vigas valores entre $80 \%$ e $90 \%$ da tensão de resistência. O modo de falha das vigas BRC1 e BRC2 nos ensaios de laboratório realizados por RAFl et al (2007) se deu através da ruptura por compressão do concreto. As tensões principais de compressão e as deformações principais no concreto obtidas no Atena situam-se em faixas de valores inferiores aos limites para esse material, não indicando ruptura por compressão do concreto como foi registrado nos ensaios. É possível ainda observar que alguns valores de tensão e deformação principais superam os limites para o concreto, entretanto, isso ocorre apenas em regiões muito próximas dos pontos de aplicações das cargas e, dessa maneira, isso foi interpretado não pela ruptura da viga através do concreto, mas sim que esses valores ocorreram devido às concentrações de tensão geradas próximas aos carregamentos. As cargas obtidas no Atena que levaram as duas vigas à fissuração demonstraram consistência com as cargas que levaram essas vigas a fissurar nos ensaios de laboratório realizados por RAFI et al (2007).

Além das vigas $B R C 1$ e BRC2, também foram analisadas duas vigas (BRS1 e BRS2) reforçadas com barras convencionais de aço. Para a viga BRS1 foi registrado o valor de $530 \mathrm{MPa}$ na armadura longitudinal de tração, valor este que representa o escoamento do aço, confirmando dessa maneira, o modo de falha da viga registrado em laboratório. Para a viga BRS2 a tensão máxima na armadura longitudinal de tração foi de $525,5 \mathrm{MPa}$, ou seja, valor bastante próximo a $530 \mathrm{MPa}$, também de acordo com o modo de falha 
registrado em laboratório. As vigas com armadura longitudinal de tração composta por barras de aço convencionais, quando simuladas no Atena, apresentaram deflexões máximas consideravelmente inferiores ao esperado de acordo com os resultados obtidos nos ensaios de laboratório.

Para constatar a validade dos resultados gerados pelo software Atena, foi realizada a análise de um problema simples passível de solução analítica simples composto por uma viga de concreto submetida a ensaio de flexão por quatro pontos e reforçada com armadura de aço. Foram analisados os resultados provenientes do software Atena e aqueles calculados através de solução analítica para os parâmetros referentes à carga de fissuração e deflexão máxima da viga. A carga de fissuração calculada pela solução analítica e aquela obtida através da simulação realizada no Atena apresentaram diferença de aproximadamente $14 \%$ entre seus valores. Já em relação à deflexão máxima calculada antes de ocorrer a fissuração na viga, ou seja, com esse elemento atuando em regime elástico, os resultados provenientes da solução analítica e do software apresentaram valor praticamente igual. A diferença entre os valores foi de apenas 3,2 \% aproximadamente. Essa análise, portanto, demonstra a consistência dos resultados gerados pelo software utilizado.

Neste trabalho também foi realizada uma comparação entre a armadura de aço e de barras de PRFC necessárias para uma viga de concreto submetida a um determinado momento fletor. O cálculo da armadura de flexão constituída por barras de PRFC seguiu a metodologia apresentada pela norma norte americana $\mathrm{ACl} 440-2015$, visto que no Brasil não existe no presente momento uma norma regulamentadora que estabeleça diretrizes para o dimensionamento de estruturas de concreto reforçadas com barras de polímero reforçado com fibras. Para o dimensionamento da armadura de flexão composta por barras de aço convencionais, foi utilizada a norma brasileira NBR 6118:2014. A análise demonstrou que para o caso estudado a armadura de aço resultou em valores superiores a aqueles encontrados considerando o cálculo apresentado na $\mathrm{ACl}$ 440-2015 para o reforço de PRFC.

Foi analisado ainda, o carregamento uniformemente distribuído que rompe uma viga contínua quando esta é reforçada com três barras longitudinais de $10 \mathrm{~mm}$ de diâmetro de aço e quando a mesma viga é reforçada com três barras longitudinais também com $10 \mathrm{~mm}$ de diâmetro, porém compostas por PRFC. Para o caso analisado no trabalho, os resultados demonstraram que o carregamento que rompe a viga reforçada com armadura de aço é ligeiramente inferior a aquele que rompe essa viga quando ela é reforçada com armadura de PRFC. Isso se dá pela capacidade de redistribuição dos 
esforços que pode ocorrer em uma viga de concreto utilizando barras de aço para reforço à flexão, caracterizando o rompimento da estrutura como ruptura dúctil. Já o PRFC apresenta regime linear elástico até a ruptura, não permitindo, portanto, que ocorra redistribuição de esforços em uma viga contínua de concreto reforçada come esse tipo de material. A capacidade de fornecer uma ruptura dúctil às estruturas de concreto faz com que o aço apresente uma vantagem importante em relação aos materiais que não permitem essa possibilidade.

Por fim, sugere-se que novos estudos sejam realizados na área da pesquisa de reforço para elementos de concreto a partir de materiais poliméricos. Esses materiais possuem vantagens em relação ao aço por não sofrerem corrosão e apresentarem maiores valores de resistência à tração. No entanto, o aço é capaz de fornecer ductilidade às estruturas de concreto e, portanto, é interessante que sejam desenvolvidos estudos com o objetivo de buscar maneiras para unir as vantagens que há nos materiais poliméricos e a ductilidade fornecida pelo aço. É importante também que a utilização de materiais poliméricos para reforço de estruturas de concreto seja mais disseminada no Brasil, pois dessa forma é possível que esse tipo de material passe a ser produzido no país e consequentemente os custos para utilizá-lo como reforço em obras brasileiras seja reduzido. 


\section{8. \\ Referências bibliográficas}

ADVANCED Tool for Engineering Nonlinear Analysis. 2D v5 DEMO. Cervenka Consulting, Disponível em: https://www.cervenka.cz/download/.

AFIFI, M. Z; MOHAMED, H. M; BENMOKRANE, B. Strength and Axial Behavior of Circular Concrete Columns Reinforced with CFRP Bars and Spirals. Journal of Composites for Construction, 2013.

American Concrete Institute. Guide for the Design and Construction of Structural Concrete Reinforced with Fiber-Reinforced Polymer (FRP) Bars. 2015.

ARCELOR MITTAL. Arcelor Mittal. Disponível em: <https://loja.arcelormittal.com.br/vergalhao-ca50-10-00-mmreto-12-metros/p>.

Associação brasileira de normas técnicas. Projeto de estruturas de concreto: Procedimento. São Paulo, 2014. 238 p.

BENMOKRANE, B; ZHANG, B; LAOUBI, K; TIGHIOUART, B; LORD, I. Mechanical and bond properties of new generation of carbon fibre reinforced polymer reinforcing bars for concrete structures. NRC Research, 2002.

BUCHAIM, R. A influência da não-linearidade física do concreto armado na rigidez à flexão e na capacidade de rotação plástica. 2001. Tese apresentada à Escola Politécnica da Universidade de São Paulo para obtenção do título de Doutor em Engenharia (Doutorado em Engenharia de Estruturas) - Universidade de São Paulo, São Paulo.

BUCHAIM, R. Concreto Estrutural: Fundamentos e Projeto. Editora da Universidade Estadual de Londrina, 2016.

CARVALHO, R.C.; FILHO, J.R.F. Cálculo e detalhamento de estruturas usuais de concreto armado. São Carlos: Editora da Universidade Federal de São Carlos, 2019. 
ČERVENKA, V; JENDELE, L; ČERVENKA, J. ATENA Program Documentation Part 1. 2018.

$\begin{array}{llll}\text { China } & \text { China.cn. } & \text { Disponível }\end{array}$ <https://detail.en.china.cn/provide/p140676866.html>.

CLÍMACO, J.C.T.S. Estruturas de concreto armado. Elsevier, 2016.

FILHO, E. S. A; REAL, M. V. Estudo comparativo entre vigas de concreto armadas com barras de aço e com barras de PRF. RETEC, 2018.

GODAT, A; ALDAWEELA, S; ALJABERI, H; TAMIMI, N. A; ALGHAFRI, E. Bond strength of FRP bars in recycled-aggregate concrete. Construction and Building Materials, 2020.

HADHOOD, A; MOHAMED, H. M; BENMOKRANE, B. Axial Load-Moment Interaction Diagram of Circular Concrete Columns Reinforced with CFRP Bars and Spirals: Experimental and Theoretical Investigations. Journal of Composites for Construction, 2016.

HILLERBORG, A; MODÉER, M; PETERSSON, P-E. Analysis of crack formation and crack growth in concrete by means of fracture mechanics and finite elements. Cement and concrete research, p. 773-782, 1976.

KHAMIES, H. T; MEDHLOM, M. K. Effect of impact load on the performance of concrete slabs reinforced by CFRP bars. Journal of Engineering and Sustainable Development, 2021.

KIMIA. Kimia prodotti e tecnologie per il recupero edilizio. Disponível em: <https://www.kimia.it/sites/default/files/docs/st/en-kimitech-tondo-cb.pdf>.

KRASNIQI, E; DAMJANOVIĆ, D; KABASHI, N. Flexural cracks in fibre-reinforced concrete beams with fibre-reinforced polymer reinforcing bars. SIMPOZIJ DOKTORSKOG STUDIJA GRAĐEVINARSTVA, 2020.

NANNI, A; DE LUCA, A; ZADEH, H.J. Reinforced concrete with FRP bars: Mechanics and Design. Taylor \& Francis Group, 2014. 
RAFI, M.M; NADJAI, A; ALI, F. Experimental testing of concrete beams reinforced with carbon FRP bars. Journal of Composite Materials, ano 2007, p. 2657-2673.

SHAMASS, R; CASHELL, K.A. Experimental investigation into the flexural behaviour of basalt FRP reinforced concrete members. Engineering Structures, ano 2020, p. 1-16.

WANG, L; YI, J; ZHANG, J; CHEN, W; FU, F. Short-term Flexural Stiffness Prediction of CFRP Bars Rein-forced Coral Concrete Beams. Materials, 2021. 